\title{
WestVirginiaUniversity
}

THE RESEARCH REPOSITORY @ WVU

West Virginia Agricultural and Forestry Experiment

Davis College of Agriculture, Natural Resources

Station Bulletins

And Design

$1-1-1966$

\section{Butt decay in yellow-poplar sprouts in West Virginia}

R. P. true

Earl H. Tryon

Follow this and additional works at: https://researchrepository.wvu.edu/ wv_agricultural_and_forestry_experiment_station_bulletins

\section{Digital Commons Citation}

true, R. P. and Tryon, Earl H., "Butt decay in yellow-poplar sprouts in West Virginia" (1966). West Virginia Agricultural and Forestry Experiment Station Bulletins. 541.

https://researchrepository.wvu.edu/wv_agricultural_and_forestry_experiment_station_bulletins/495 @ WVU. It has been accepted for inclusion in West Virginia Agricultural and Forestry Experiment Station Bulletins by an authorized administrator of The Research Repository@WVU. For more information, please contact ian.harmon@mail.wvu.edu. 
West Virginia University Libraries

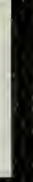

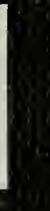

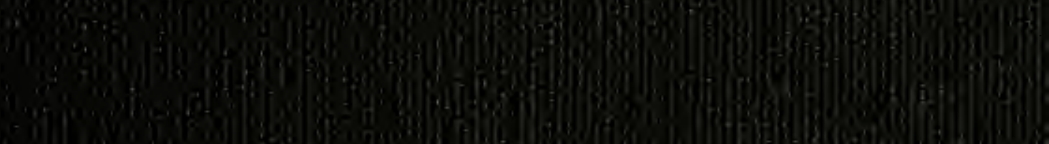

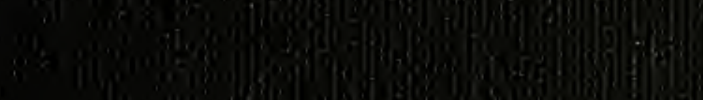
10 - 15 嗐 
Digitized by the Internet Archive in 2010 with funding from

Lyrasis Members and Sloan Foundation 


\section{BUTT DECAY IN}

YELLOW-POPLAR SPROUIS IN WEST VIREINIA

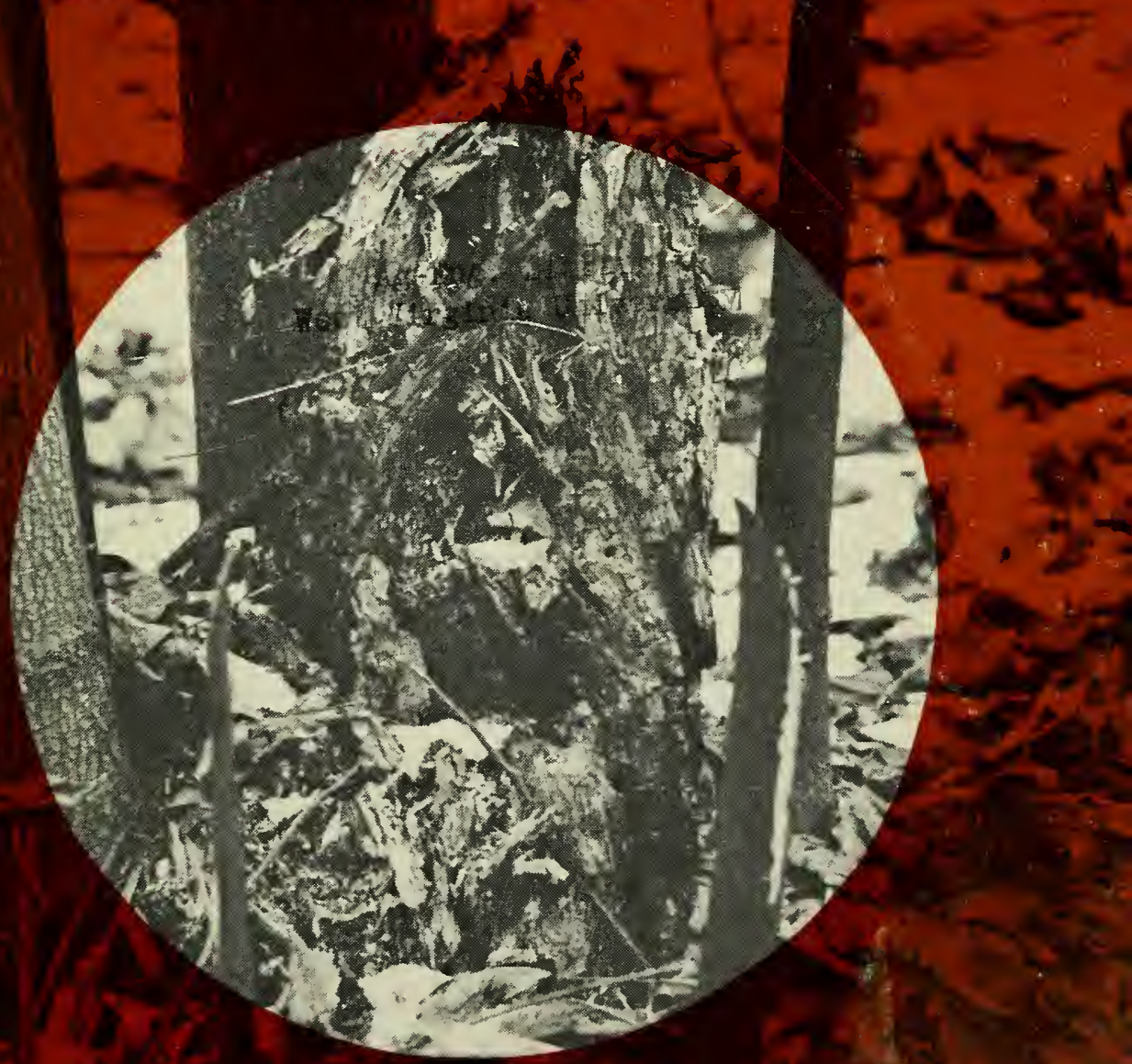

WEST VIRGINIA UNIVERSITY 


\section{THE AUTHORS}

R. P. True is Plant Pathologist and E. H. Tryon is Silviculturist in the West Virginia University Agricultural Experiment Station.

West Virginia University Agricultural Experiment Station College of Agriculture and Forestry

A. H. VANLANDINGHAM DiRECTOR

(December 1967) 


\section{Contents}

I. Yellow-poplars grow from seeds and sprouts $\ldots \ldots \ldots \ldots \ldots$.

Seedling stands $\ldots \ldots \ldots \ldots \ldots \ldots \ldots \ldots \ldots \ldots \ldots \ldots \ldots \ldots$

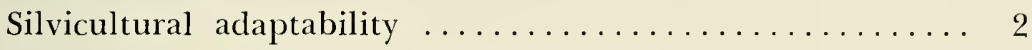

Hardwood sprout stands ..................... 3

II. Early fungus invasion of cut stumps $\ldots \ldots \ldots \ldots \ldots \ldots \ldots 7$

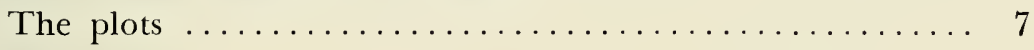

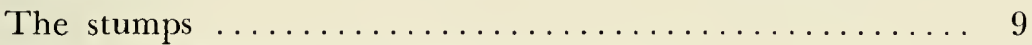

Patterns of discoloration and decay in stumps $\ldots \ldots \ldots \ldots .10$

Fungi characteristically found at different depths in stumps of seedling sprouts cut the previous year ......... 14

Fungi isolated from specific regions of discoloration

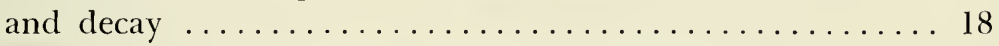

Softening of the wood associated with 3 sapwood symptoms and the fungi isolated.

III. Discoloration, decay and disintegration of wood in stumps

and stump sprouts. ....................... 23

The disappearance of wood from the aging stump and from its root system ...................... 23

Patterns of discoloration and decay in stumps cut 14 , 18 and 22 years previously and in their roots and

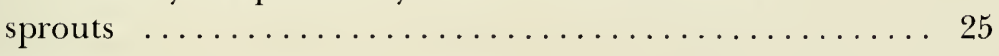

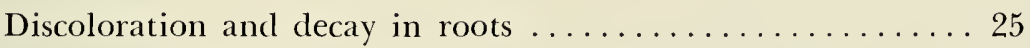

Discoloration and decay in stumps and sprouts $\ldots \ldots \ldots 27$

The heartwood or pathological heartwood connection ........................... 29

The nature of butt decay found in stump sprouts . . . . . 29

Factors favoring the incidence of butt rot in stump sprouts $\ldots \ldots \ldots \ldots \ldots \ldots \ldots \ldots \ldots \ldots \ldots \ldots \ldots \ldots \ldots$

Sprouts originating high on the stump $\ldots \ldots \ldots \ldots \ldots . \ldots 31$

Sprouts from the larger stumps $\ldots \ldots \ldots \ldots \ldots \ldots \ldots \ldots 1$

Decay spread faster through the stems of sprouts with suppressed crowns $\ldots \ldots \ldots \ldots \ldots \ldots \ldots \ldots \ldots \ldots \ldots$

Organisms isolated from representative samples $\ldots \ldots \ldots \ldots 32$ 
IV. Part A, Butt rot in stem selected for crop trees (elite stems) of thinned sprout clumps ................ 39

Stumps of stems removed in thinning as infection courts

for butt rot of elite stems . . . . . . . . . . . . 33

The stumps and elite stems 5 and 8 years after

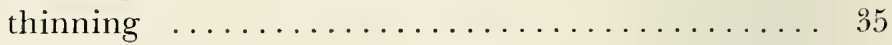

The fungi isolated from discolored and decayed butts of elite stems.

The special suitability of seedling sprouts for studies of decay entrance through ancillary stems or

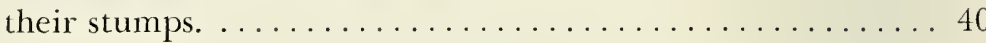

IV, Part B, Butt rot in stems selected for crop trees (elite stems) of nonthinned sprout clumps.

Dead ancillary stems of nonthinned seedling sprout clumps as infection courts for butt rot of elite stems The stage of ancillary-stem decay as an indicator of butt rot in the elite stem ................ 4I

Incidence and types of heartwood connection in relation to the incidence of decay in the elite stem

Characteristics of the elite stem influencing the incidence of butt rot of ancillary-stem origin

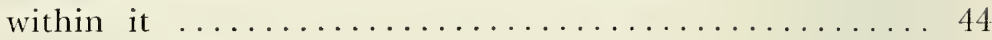

Tree vigor index $\ldots \ldots \ldots \ldots \ldots \ldots \ldots \ldots \ldots \ldots \ldots \ldots \ldots \ldots$

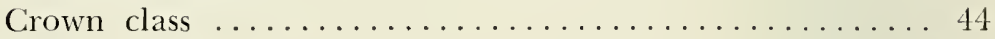

Elite-stem diameter $\ldots \ldots \ldots \ldots \ldots \ldots \ldots \ldots \ldots \ldots \ldots$

Total height $\ldots \ldots \ldots \ldots \ldots \ldots \ldots \ldots \ldots \ldots \ldots \ldots \ldots \ldots \ldots$

Radial growth rate $\ldots \ldots \ldots \ldots \ldots \ldots \ldots \ldots \ldots \ldots \ldots \ldots$

The fungi chiefly responsible for discoloration and decay .... 48 Summary of relationship of decay in elite seedling sprout stems as associated with dead ancillary stems of the same clump

Factors found affecting butt rot incidence in sprout yellow-poplar as compared with some previously reported for other species 
V. Microorganisms associated with butt decay in sprout yellow-poplar. ........................ 51

Infection courts for felamentous fungi $\ldots \ldots \ldots \ldots \ldots \ldots \ldots 51$

Survival and spread of microorganisms within living trees. . . . 52

Possible nutritional interrelationships within the stump

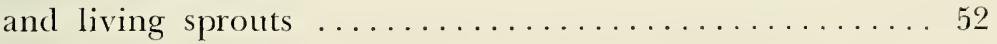

Sequence and interaction among invading organisms ...... 53

VI. Application to forestry practice ................. 55

General importance of decay in sprout yellow-poplar

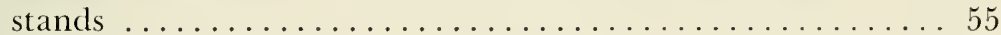

Types of decay and economic importance ........... 56

Vigor index and site quality .................. 57

Intermediate cuttings $\ldots \ldots \ldots \ldots \ldots \ldots \ldots \ldots \ldots \ldots \ldots$

Cleanings or weedings $\ldots \ldots \ldots \ldots \ldots \ldots \ldots \ldots \ldots \ldots \ldots \ldots$

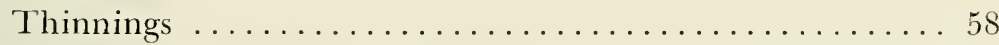

A summary of recommendations $\ldots \ldots \ldots \ldots \ldots \ldots \ldots 60$ 



\section{Butt Decay in Yellow-Poplar Sprouts In West Virginia}

R. P. TRUE and E. H. TRYON

\section{Yellow-Poplars Grow From Seeds or Sprouts}

Yellow-poplar (Liriodendron tulipifera L.) is often called the tulip tree because of the appearance of its showy flowers. The moderately soft wood and the yellow or greenish yellow heartwood make "yellow-poplar" the foresters' choice for the common name of this tree that is not truly a poplar, but a member of the Magnoliaceae (Little, 1953).

\section{SEEDLING STANDS}

Germination percentages of yellow-poplar seed range from less than 5 to nearly 35 per cent (Boyer and Kaeiser, 1961) but so many seeds are produced annually on trees over eight inches dbh (Carvell and Korstian, 1955) that its comparatively low percentage of viable seed seldom limits seedling reproduction in the vicinity of seed-bearing trees (Guard and Wean, 1941). The winged seeds of the cone-like compound fruits usually fall within 600 feet of the parent tree (Boyce and Kaeiser, 1961) or within a distance equal to four to five times the height of the tree (McCarthy, 1933) although under some conditions they may be carried up to a mile.

Yellow-poplar is intolerant of shade and trees seldom survive if overtopped. Seedlings seldom develop on the undisturbed litter of the forest floor (Phillips, 1962). Seeds germinate and become established best on exposed mineral soil in clear-cut areas or in openings large enough to admit sufficient light. (Trimble and Hart, 1961). The exposure of mineral soil in cutting and logging is often sufficient to permit adequate seedling establishment (Engle and Williams, 1957) but special soil-scarifying operations such as disking may be used if necessary.

Yellow-poplar is sensitive to flooding (Putnam, Furnival and McKnight, 1960), to freezing (Funk, 1958; Tryon and True, 1952 and 1964), and may be killed or have its growth checked severely by drought (Tryon and Carvell, 1960; Tryon and Myers, 1952; Tryon, Cantrell and Carvell, 1957). Yellow-poplars grown on unfavorable sites make slow growth (Trimble and Hart, 1961) and disease may reduce the volume and quality of the wood (Dochinger and Seliskar, 1962). On deep, rich 
soils with adequate moisture, yellow-poplar grows faster than most other hardwoods (Doolittle, 1958). Stands of seedling origin suffer little from disease or even decay except following wound infection (Hepting and Hedgcock, 1937 and Roth, 1941). Such trees show but few important defects (Putnam, Furnival and McKnight, 1960). The selection of highly productive sites is of primary importance for the production of highquality yellow-poplar. Such conditions are present on north and east slopes in the Appalachians.

\section{SILVICULTURAL ADAPTABILITY}

Yellow-poplar has a botanical range that extends from southern New England west to southern Michigan, south to central Louisiana, and eastward to the Atlantic coast of northern Florida (Renshaw and Doolittle, 1958). It is the major species of the cove hardwood timber type (Strausbaugh and Core, 1964) and occupies valleys in the Appalachian Mountains, and deeper, richer soils of the Piedmont, the Coastal Plain and midwestern woodlands, mostly east of the Mississippi River (Betts, 1954). Yellow-poplar has received silvicultural attention as a major forest resource in West Virginia and southward. Recently separate site index curves have been provided for this species in the southern Appalachian Mountains and in the Piedmont (Doolittle, 1958 and Beck, 1962). While Piedmont site index values ${ }^{1}$ agree well with those previously given for this species throughout its range (McCarthy, 1933), the curves for the Appalachians are generally lower up to 50 years and higher above this age (Beck, 1962).

On good sites yellow-poplar grows rapidly and produces valuable products including commercial veneer and high-quality lumber. In West Virginia, many valuable stands have seeded in and grown up on old agricultural lands close to good roads (Holcomb and Bickford, 1952). Some of these sites may be so managed as to produce more revenue than could be expected from cultivation or grazing (Holsoe, 1950).

Campbell (1959) reported that tree grade in new stands of yellowpoplar can be reliably estimated and confidently used in thinning for lumber, particularly if site differences are recognized and considered. The advantages of thinning yellow-poplar stands in the cove hardwoods type have been explored or demonstrated (Holsoe, 1950, 1951; Wahlenberg, 1953; Holcomb and Bickford, 1952; Carvell, 1964).

${ }^{1}$ Site index is a method of evaluating numerically the productivity of a site for a species growing in even-aged stands. The site index value is the height in feet of dominant and codominant trees at a designated age. For eastern species age 50 is used. Thus a site index value of 80 for a site where yollow-popular is grown means that the tallest yellow-popular trees will be 80 feet tall when they are 50 years old. 


\section{HARDWOOD SPROUT STANDS}

There is little information available on sprouting or sprout stands of yellow-poplar (McCarthy, 1933; True, 1953) although this species is one of several which reproduce successfully by stump sprouts as well as from seed. Yellow-poplar sprouts arise chiefly from pre-existing dormant buds situated near the base of dead or dying stems or above or below the soil line on stumps. The oaks, maples, ash and basswood have sprouting characteristics similar to yellow poplar. Members of this group differ from beech, where the sprouts originate as stool shoots from adventitious buds that arise in wound callus at or near the stump top. Aspen and locust usually reproduce by root suckers (Hawley and Smith, 1954).

Sprouts arising from very small stumps (2 inches or less in diameter) are called seedling sprouts to distinguish them from stump sprouts produced on larger stumps (Leffelman and Hawley, 1925). Even though both arise from stumps, scedling sprouts have some of the characteristics of seedling trees partly because their small stumps lack heartwood, which often serves in larger stumps as an infection court for serious sprout decay, and partly because they are soon engulfed by the base of the expanding scedling sprout. Conversely, larger stumps may contain heartwood and persist longer as open infection courts. Sprouts arising from stumps may at first grow away from the stump before they grow vertically (Figure 1). The bases of such stump sprouts are more likely to show a sweep defect than are the sprouts from very small stumps. Basal butt swell may occur after larger parent stumps have been overgrown (Figure 6-B). Trees from seedlings seldom show pronounced sweep or butt swell.

Two or more sprouts may grow and survive to produce a sprout clump from a single stump (Figure 2). Trees of seedling origin are usually single stemmed, but seedlings that have repeatedly lost the terminal bud through injury by such agencies as freezing, grazing, or deer browse sometimes produce multiple-stemmed trees which are difficult to distinguish from sprout clumps.

Bud traces, which connect the dormant bud to the pith, elongate as the cambium adds radial thickness to the stem, unless the upper part of the tree is cut or dies or loses vigor. Then, freed from the apical dominance of the parent stem which suppressed them, such buds begin to elongate, first like a lateral branch and then upward. Dormant buds are formed when the parent stem is small (Roth and Sleeth, 1939) and maintain their structural and functional connection with the central portion of the parent stem (Figure 3). The sprout forms its own heartwood when it is an inch or two in diameter, usually at or near a node or nodes 1 to 3 


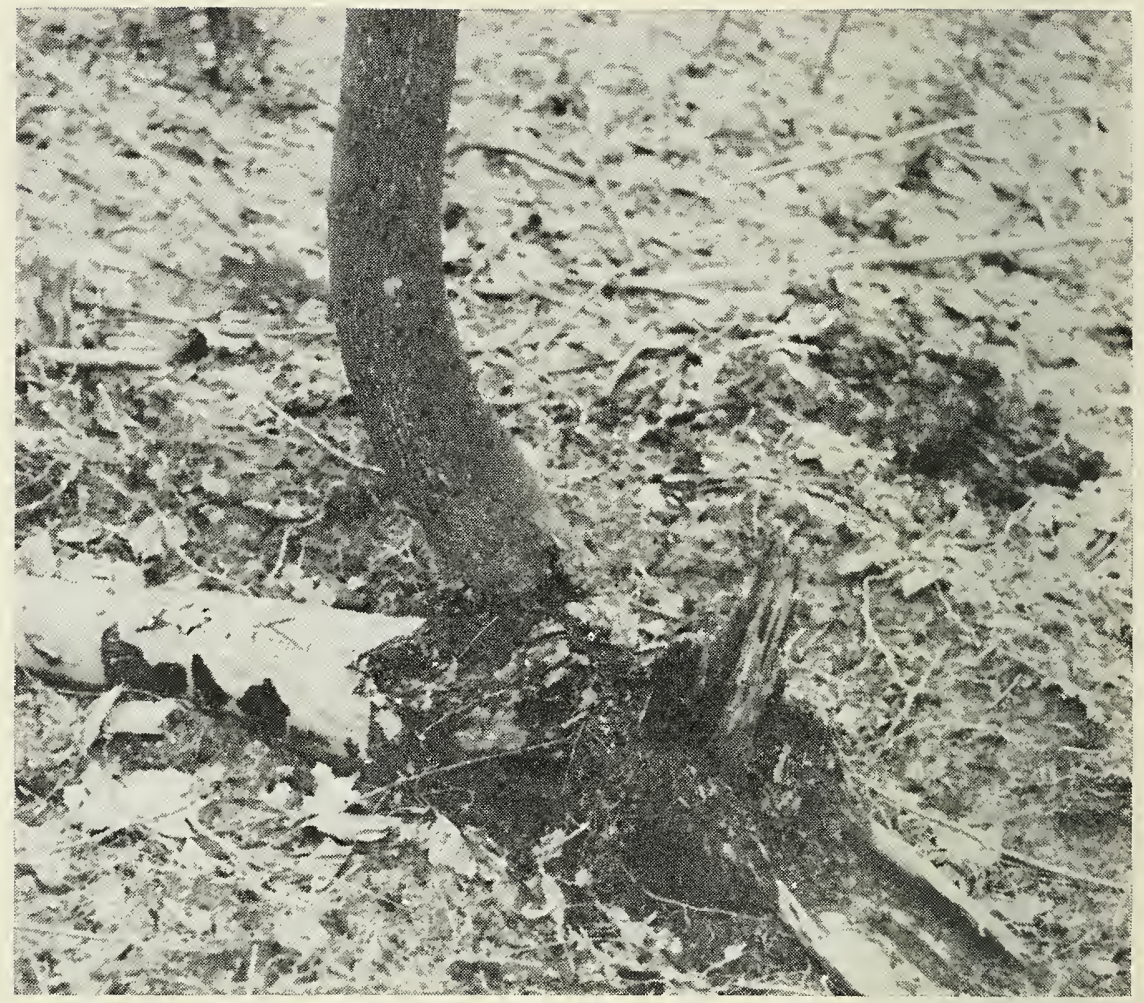

FIGURE 1. Sweep defect in butt of a young stump sprout which grew out away from the stump before it turned upward.

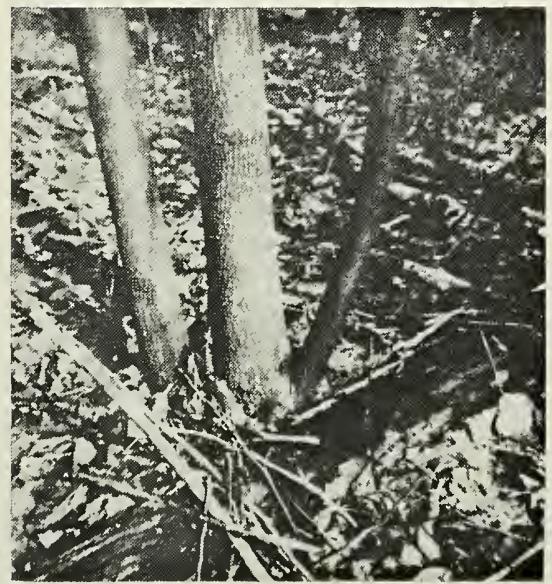

FIGURE 2. A clump of three seedling sprouts of different sizes but all presumably of the same age. The smallest sprout of this group may be suppressed and die before the center sprout is large enough to harvest. 

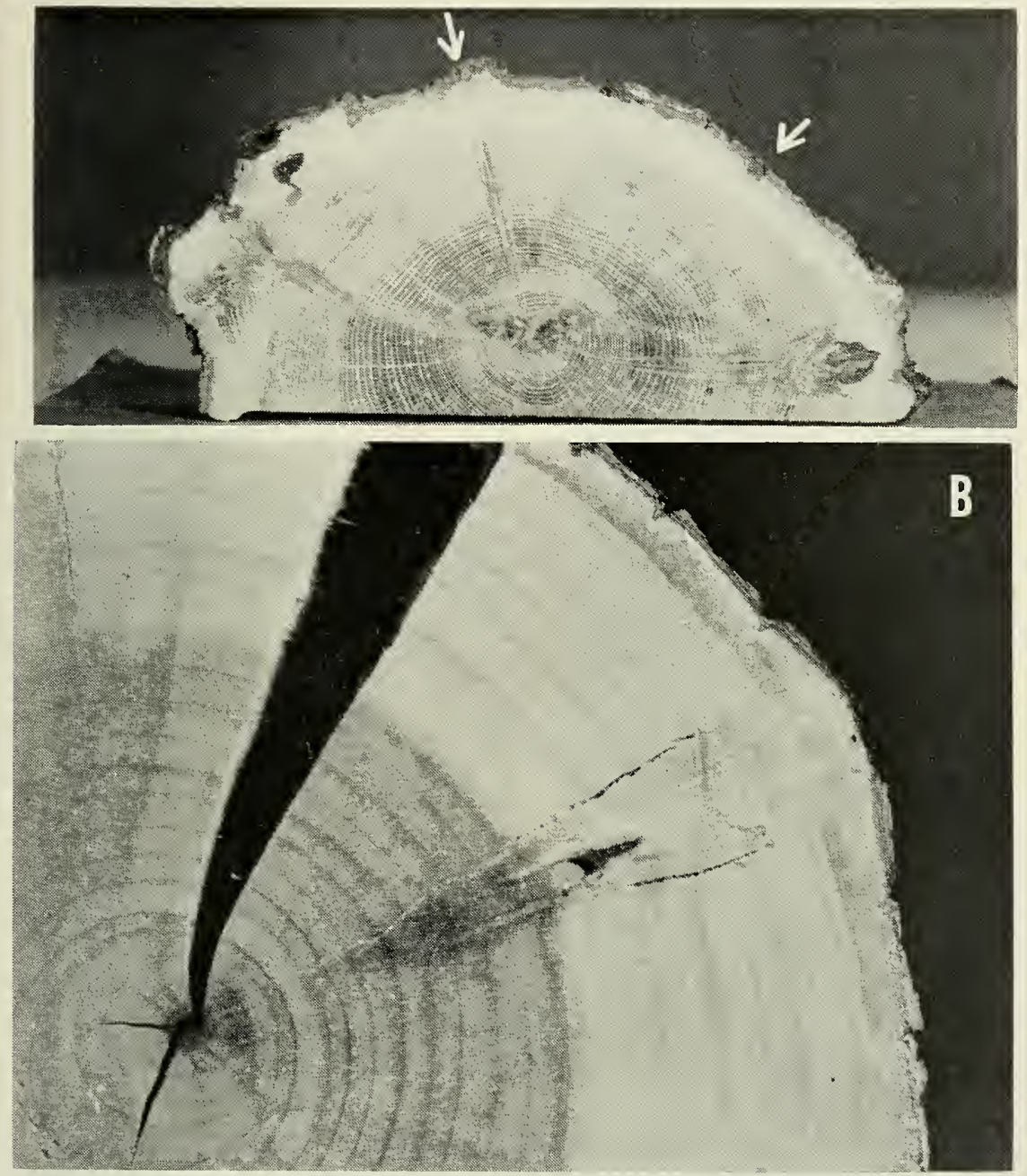

FIGURE 3. Dormant buds and the vascular connections (traces) that unite them with the heartwood. 3-A two dormant buds in an oak stem and their traces. 3-B, three dormant buds in the outer bark of yellow-poplar joined by three traces to a single trace of the original solitary dormant bud. Most dormant buds in yellowpoplar, as in oak, are solitary, and a single trace connects them with the heartwood.

feet above its point of origin on the stump (Roth and Sleeth, 1939; Byler and True, 1966). This conversion of sapwood to heartwood within the sprout spreads both upward and downward in the center of the sprout. In its downward development it ultimately joins the heartwood of the parent stump. What has been termed a heartwood connection is then established between the maturing sprout and the stump from which it arose (Figure 4-A). 


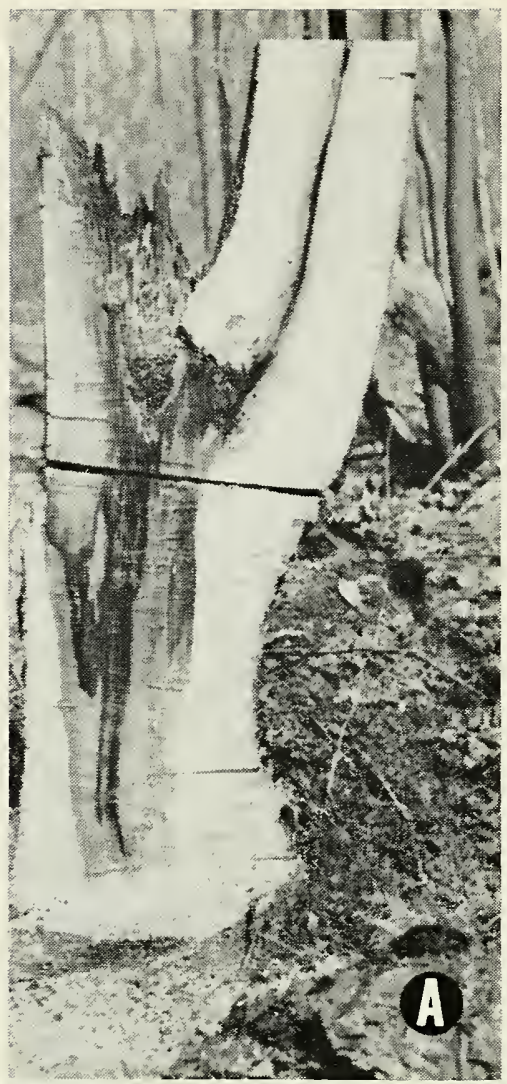

FIGURE 4. The distribution of heartwood within a stump and its connection with that of a large high-origin sprout. 4-A, The heartwood union connecting the heartwood of a high-origin sprout with that of the decaying parent stump has permitted decay to pass from the stump into the sprout, where it has caused pith-centered decay. Note that within the parent stump the heartwood diminiches toward the ground line. 4- $\mathrm{B}$, a cross section of the stump near the ground line shows a small, irregularly shaped heartwood region. 4-C, a cross section of the same stump made two inches below the ground line shows no heartwood.
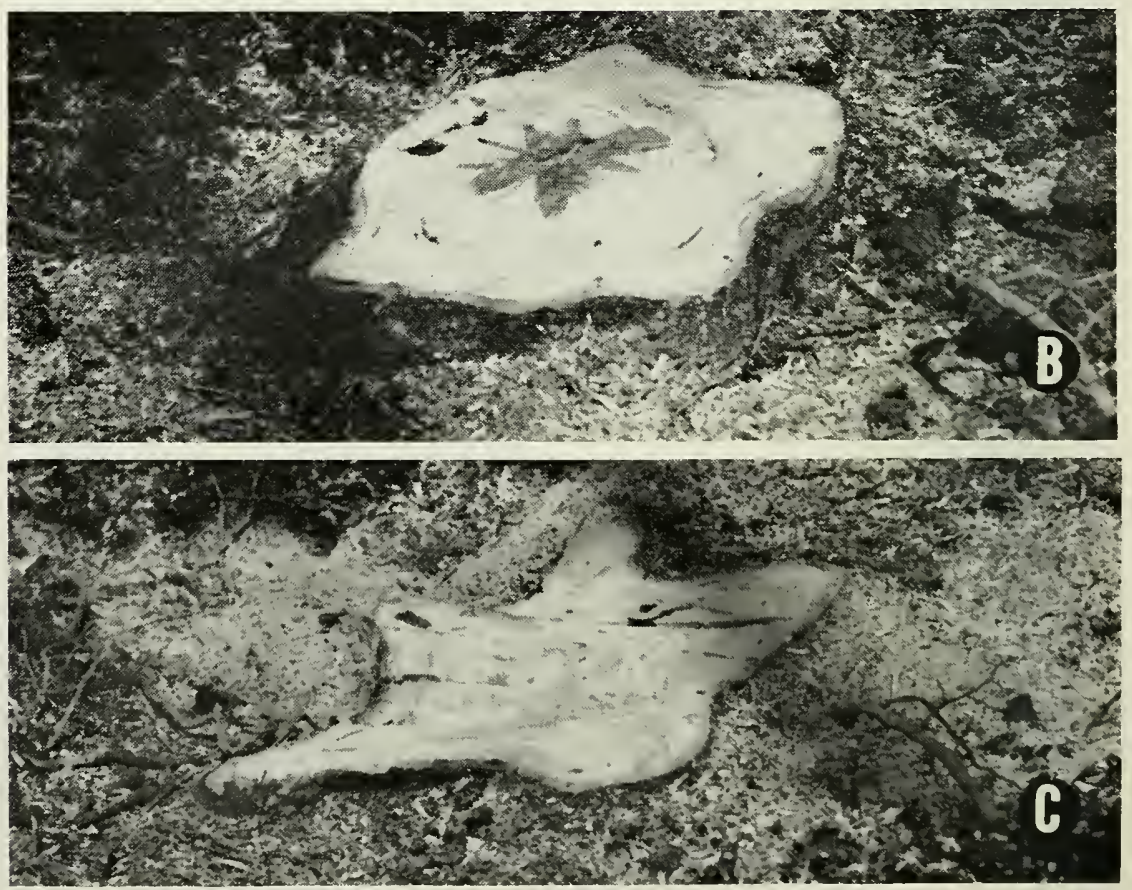
Sprouts arising from roots or from the stump below ground usually lack a heartwood connection with the stump heartwood since the roots and below-ground portions of the stump do not normally contain heartwood (Figure 4-B, C). Sapwood tissues separating heartwood columns of stump and sprout may prevent heart-rot fungi which enter the stump heartwood from spreading into the heartwood column of the sprout.

Since stump sprouts inherit the surviving root system of the parent stump, sprouts (unlike seedlings) are assured of an adequate initial water supply. The initial growth rate of yellow-poplar sprouts so far exceeds that of young seedlings that where the two are in clirect competition the faster-growing sprouts survive and the seedlings die (Renshaw and Doolittle, 1958).

Despite their faster early growth, sprouts are often discriminated against by land managers in favor of seedlings for several reasons. Once they are well established, seedlings may grow at a faster rate than sprouts of a like age. The succulent growth of sprouts may not harden off in time to escape injury from early frosts (Boyce, 1961). Butt rot is more prevalent in sprouts than in seedlings.

Much second-growth yellow-poplar is of mixed sprout-and-seedling origin, with the more desired seedlings likely to be suppressed by the vigorous early growth of competing sprouts. Old fields and pastures will at first be occupied by stands of seedling origin. After the first heavy cutting sprouts may be expected to develop. Although the land manager may wish to deal with stands of seedling yellow-poplar, he will need to know how best to handle the sprouts and seedling-sprouts so often associated with them.

The purpose of this bulletin is to present information about sprout stands of yellow-popular and especially about their management with respect to butt decay.

\section{Early Fungus Invasion of Cut Stumps}

\section{THE PLOTS}

In 1952 study plots were established in three young sprout stands of yellow-poplar in the Coopers Rock Forest near Morgantown. Plot trees were seedling sprouts 1 to 6 inches dbh and approximately 18 years old. Most of them contained heartwood although sprout diameter varied greatly among even-age sprouts of the same clump.

Plot 1, situated near the top of Chestnut Ridge at an altitude of about 2,600 feet, included 24I single-stemmed sprouts and sprout clumps. Plot 2, near Quarry Run where it crosses highway 73 at an approximate altitude of 1,700 feet, consisted of 253 sprout clumps and single-stemmed 
sprouts. Plot 3 was situated close to the highway and north of it at a point between plots 1 and 2. It contained 248 single-stemmed sprouts and sprout clumps.

Forty-two per cent of the seedling sprouts in all three plots were single stemmed. The remaining 58 per cent were multiple-stemmed clumps made up of from 2 to 6 sprouts, with 31 per cent being 2-sprout clumps, 14 per cent having 3 sprouts, 8 per cent were 4 -sprout clumps, and the 5-and 6-sprout clumps made up only 3 and 2 per cent of the total, respectively. The average diameter of each sprout in multiple-sprout clumps was only slightly less than that of single stems standing alone. The toal stem diameter per sprout clump therefore increased with the increasing number of sprouts produced per clump (Figure 5).

Single-stemmed sprouts approaching pulp or mine-prop size were felled and examined for decay. Nine per cent contained some butt-decay, usually associated with basal cankers considered due to frost since the areas had not been burned after the development of the seedling sprout stand. Although heartwood was present in the base of nearly all sprouts containing decay, only a small percentage of them appeared

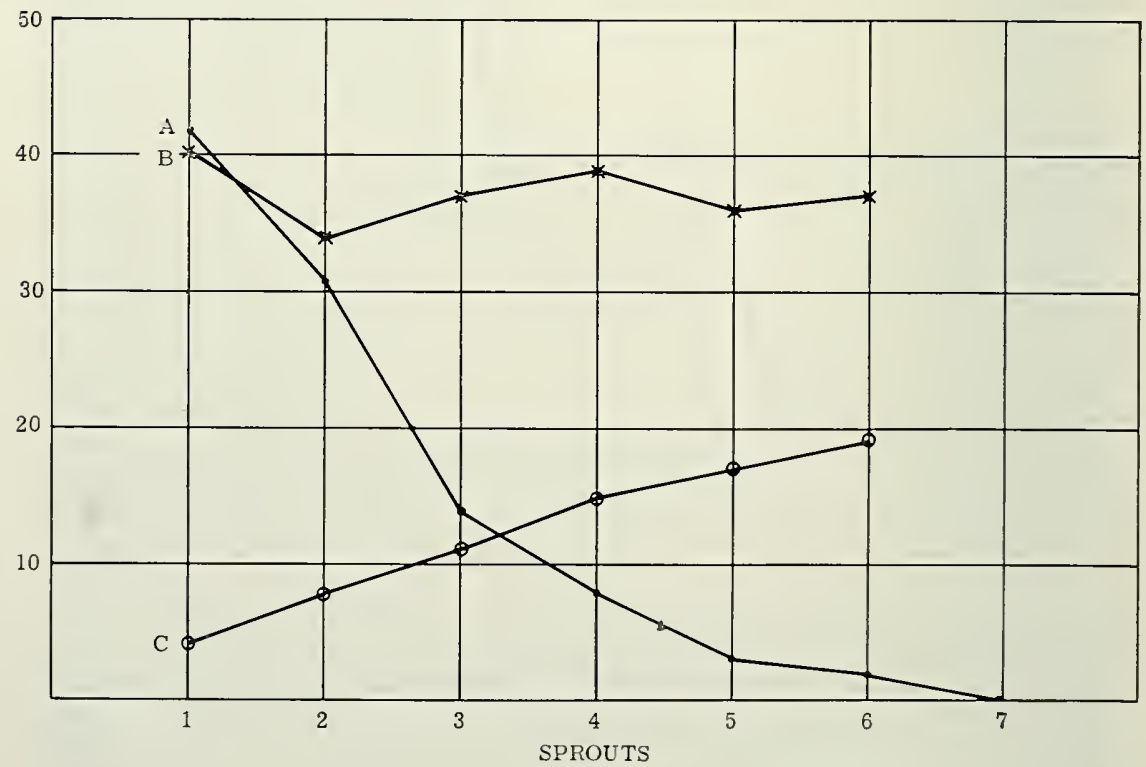

FIGURE 5 (Graph 1). Percentage of all sprouting stumps producing 1, 2, 3, 4, 5 and 6 sprouts. respectively. (Figures on vertical axis indicate values as follows): Curve $\mathrm{A}=$ Percentage total stumps with designated number of sprouts. Curve $\mathrm{B}=$. Irerage diameter of each sprout in each designated sprout group. Curve $\mathrm{C}=$ Average total diameter of all sprouts in each designated sprout group. 


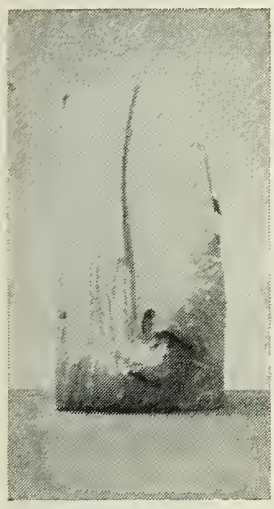

A

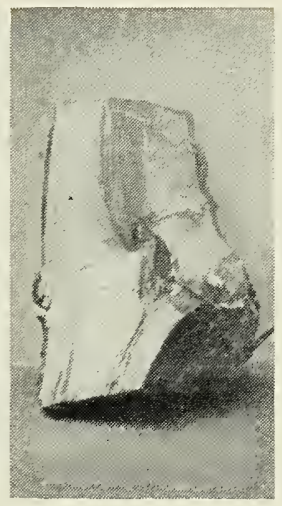

B
FIGURE 6. J-shaped pith unions of sprouts with their parent stumps. 6-A, shows pith union between a seedling sprout and its small-diameter parent stump. 6-B, shows union of a sprout with a somewhat larger parent stump and the butt swell in the sprout base where it has engulfed the parent stump.

to have been infected through the parent stump. Presumably this was partly due to their being seedling sprouts (Figure 6-A) .

\section{THE STUMPS}

All sprouts except the largest and/or the best-formed stem were removed from each sprout clump during 1953, simulating precommercial thinnings. Half of this cutting was done during the spring dormant season. The remainder were cut in June. The tops of half of the stumps were treated with a commercial tree-wound dressing and the remainder were untreated. In 1954, one year after cutting, 23 stumps of sprouts from 13 sprout clumps which had received a variety of treatments (Appendix Table l) were cut off at the ground line, dissected, examined, and described. Isolations were attempted in order to determine the fungi associated with different types and patterns of discoloration and decay in different parts of the stump. Tests of the comparative softness of the wood showing different discolorations were made using a spring-testing device. Because of the limited nature of the unbalanced sample, it was not possible to draw significant conclusions concerning the effect of season of cutting or of the treatment of the stump-top with tree wound dressing on the entrance of decay.

The sprout stumps studied varied in height from 7.5 to $22.4 \mathrm{~cm}$ and in top diameter between 2.5 and $14.4 \mathrm{~cm}$. Distances downward from the stump tops to the isolation areas were expressed as percentages of the total stump height to compensate partly for the variability in the height of different stumps. A splitting dissection technique permitted culturing from tissues at selected isolation areas on one side of a split and permitted the preservation of the corresponding tissues on the opposite side for other 
Table 1. Combinations of Fungi Most Commonly Isolated When Two Fungi Came from the Same Isolation Area

A. When the Isolation Area Showed a Single Symptom

\begin{tabular}{|c|c|c|c|c|c|c|}
\hline & $\begin{array}{l}\text { Fusarium } \\
\text { sp. No } 1\end{array}$ & $\begin{array}{c}\text { Phomopsis } \\
\text { sp. }\end{array}$ & $\begin{array}{l}\text { Peniophora } \\
\quad s p .\end{array}$ & $\begin{array}{l}\text { Pleurotus } \\
\text { ostreatus }\end{array}$ & $\begin{array}{l}\text { Polyporus } \\
\text { adustus }\end{array}$ & $\begin{array}{l}\text { Polyporus } \\
\text { versicolor }\end{array}$ \\
\hline Fusarium sp. No. 1 & - & 0 & 2 & 2 & 1 & 0 \\
\hline Phomopsis sp. & & - & 1 & 0 & 0 & 1 \\
\hline Peniophora sp. & & & - & 0 & 2 & 0 \\
\hline Pleurotus ostreatus & & & & - & 0 & 0 \\
\hline Polyporus adustus & & & & & - & 0 \\
\hline$P$. versicolor & & & & & & - \\
\hline Totals & 0 & 0 & 3 & 2 & 3 & 1 \\
\hline
\end{tabular}

B. When the Isolation Area Showed Two Symptoms

\begin{tabular}{|c|c|c|c|c|c|c|}
\hline $\begin{array}{l}\text { Fusarium sp. No. } 1 \\
\text { Phomopsis sp. } \\
\text { Peniophora } \mathrm{sp} . \\
\text { Pleurotus ostreatus } \\
\text { Polyporus adustus } \\
\text { P. versicolor }\end{array}$ & - & $\begin{array}{c}0 \\
-\end{array}$ & $\begin{array}{c}1 \\
1 \\
-\end{array}$ & $\begin{array}{c}1 \\
0 \\
0 \\
-\end{array}$ & $\begin{array}{c}2 \\
0 \\
1 \\
0 \\
-\end{array}$ & $\begin{array}{l}0 \\
1 \\
0 \\
0 \\
0 \\
-\end{array}$ \\
\hline Totals & 0 & 0 & 2 & 1 & 3 & I \\
\hline
\end{tabular}

descriptive and experimental studies (Figure 7). Isolation areas one inch long permitted the removal of several chips from each (Figure 8). Usually the whole length of the isolation area lay within a single symptom region. Several crossed the boundaries between symptom regions, and isolations were made from two or more symptom regions.

\section{PATTERNS OF DISCOLORATION AND DECAY IN STUMPS}

It is possible to distinguish five kinds (symptom classes) of internal discoloration and/or decay of sapwood and five kinds in the heartwood of stumps cut one year previously, which are below (see also Figures 8 and 9$)$ :

$\begin{array}{cl}\text { Symptom Class } & \text { Sapwood Symptoms } \\ 1 & \text { Dark stain from stump top } \\ 2 & \text { Light tawny regions } \\ 3 & \text { Diffuse brown stain } \\ 4 & \text { Diffuse gray stain } \\ 5 & \text { Diffuse light brown } \\ & \text { discoloration }\end{array}$

Heartwood Symptoms

Dark brown stain

Tawny regions

Brown stain

Dark olive green stain

Purple stain

Symptoms of Class 1 in both sapwood and heartwood were found at and just beneath the top of the stump. The dark stain characteristically 

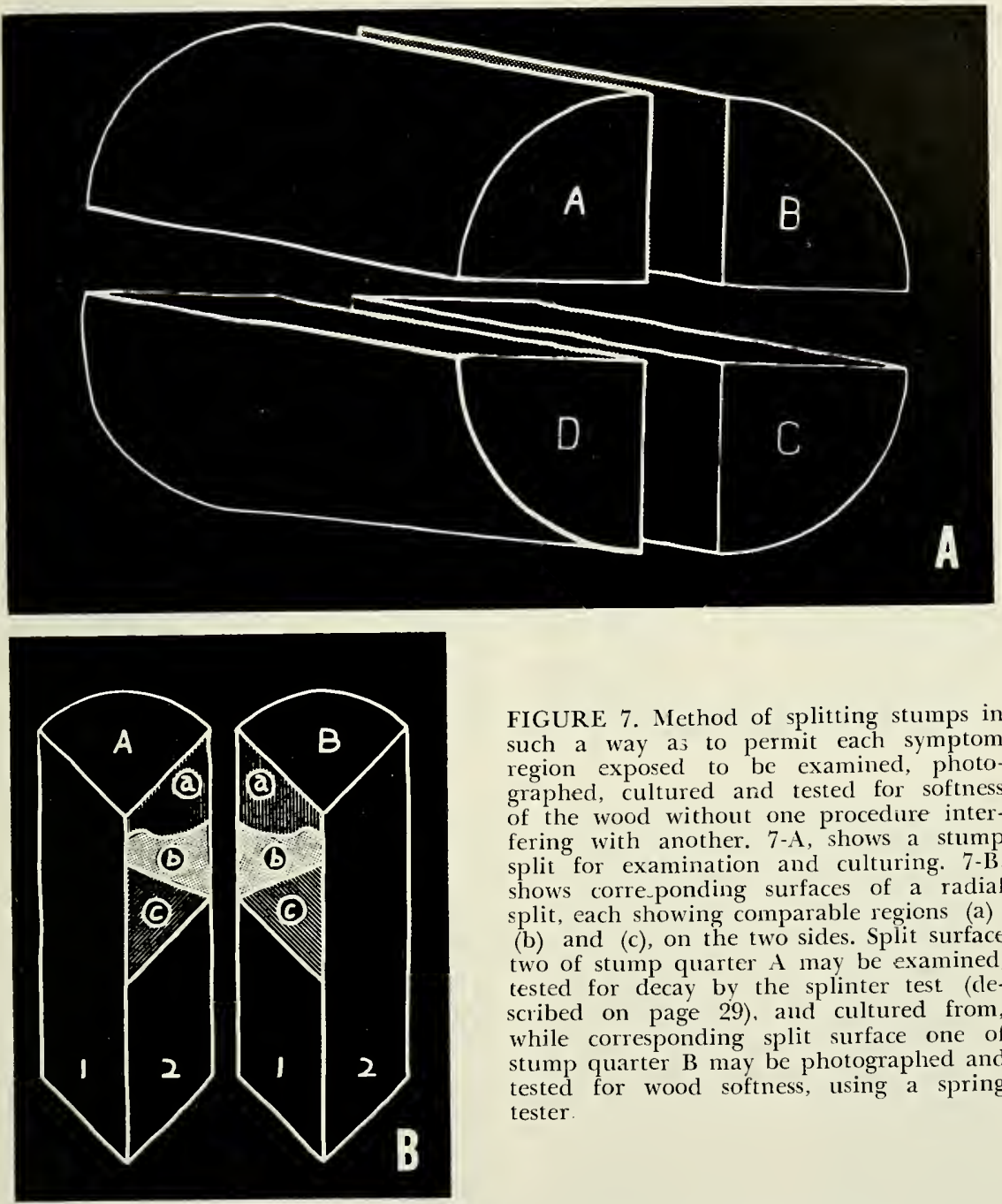

FIGURE 7. Method of splitting stumps in such a way as to permit each symptom region exposed to be examined, photographed, cultured and tested for softness of the wood without one procediure interfering with another. 7 -A, shows a stump split for examination and culturing. 7-B, shows corre-ponding surfaces of a radial split, each showing comparable regions (a), (b) and (c), on the two sides. Split surface two of stump quarter A may be examined, tested for decay by the splinter test (described on page 29), and cultured from, while corresponding split surface one of stump quarter B may be photographed and tested for wood softness, using a spring tester

found in sapwood at the stump top sometimes extended far down into the stump but then only close to the cambium and only when the bark was dead. The appearance of this sapwood symptom suggests that of wood stained by the action of blue-stain fungi, although the color is more black than blue.

The tawny regions in sapwood and heartwood (Symptom Class 2) were not always present and were a comparatively late development when they did occur. Wood of the tawny regions was often obviously weakened, and it could sometimes be easily indented with the thumbnail. Tawny 

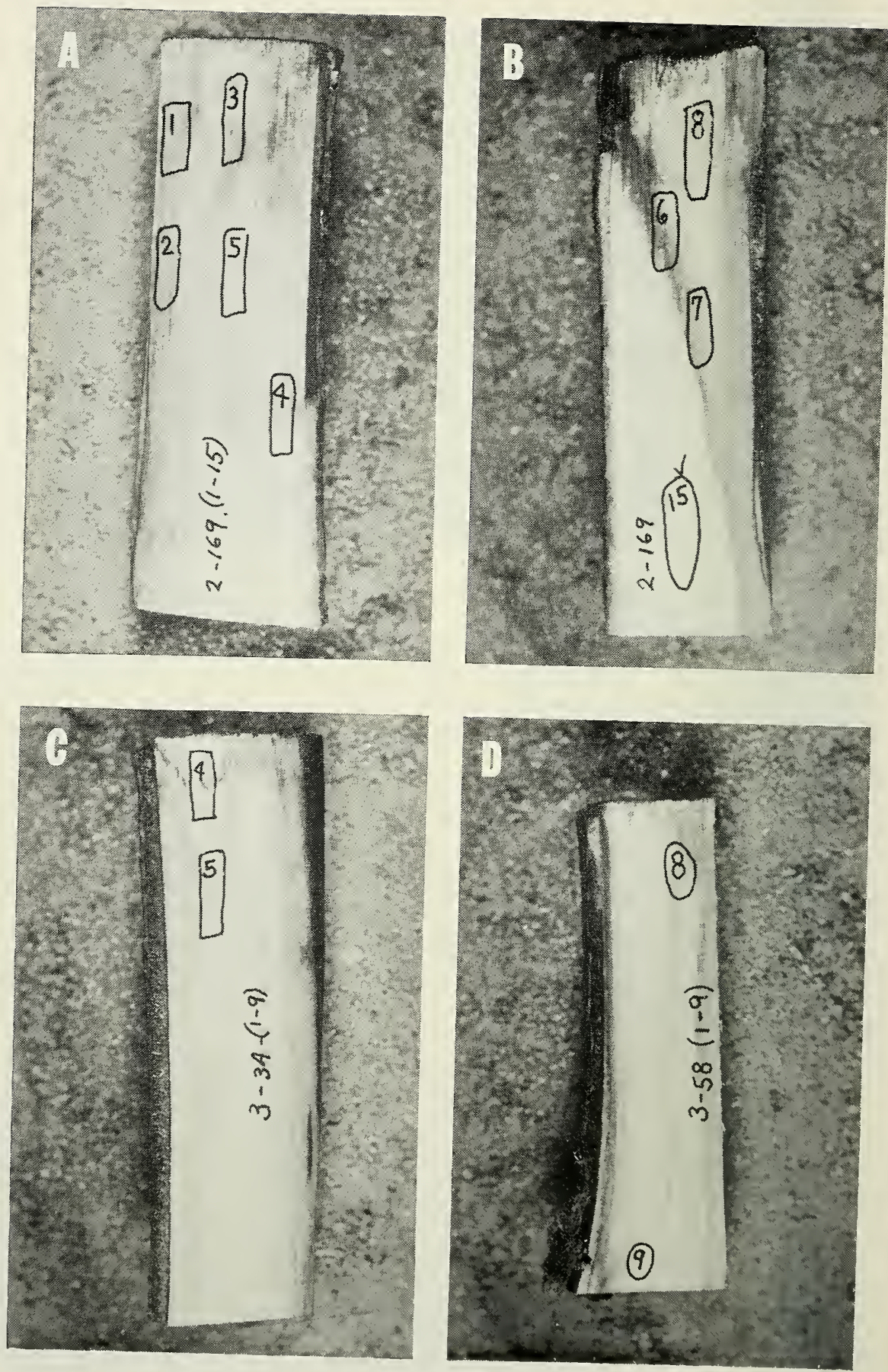
FIGURE 8. Split surfaces of stumps showing symptom regions and areas marked for fungus isolation. 8-A shows stump 196 of plot l, face l: bark dead more than half way down from the stump top, heartwood present; dark stain shown at stump top. Isolation areas one (heartwood) and three (sapwood) are both within the light tawny region. They yielded Polyporus adustus and Polyporus versicolor, respectively. Isolation area two, in dark brown heartwood stain, yielded Polyporus adustus. Isolation area four, involving the border of the tawny region and the diffuse light brown stain below, vielded Peniophora sp. Isolation area five, in the midst of the light tawny region of the sapwood, yielded Polyporus versicolor. 8-B shows face two of the same stump; bark alive nearly to the top of the stump, heartwood present; dark stain localized at stump top, isolation area eight, included within the light tawny region, yielding both Polyporus adustus and Schizophyllum commune; isolation areas six and seven within a region of dark brown stain, yielding Fusarium sp. \#l and Schizophyllum commune, respectively. No fungus grew from isolation area 15 situated in bright white sapwood. 8-C shows stump 3-A of plot two, face three; bark all dead but adhering to the wood, heartwood present; the dark stain at stump top especially clear; isolation area four, half within it and half within the light tawny below, yielded an undetermined basidiomycete, isolation area five, including the lower edge of the light tawny region and extending into the light brown region below, yielded Peniophora sp. 8-D, Stump 58 of plot two, face four: bark all dead and mostly adhering, heartwood present; isolation area eight in dark brown heartwood region yielding a fungus lost through contamination, isolation area nine deep in the light tawny region, yielded Polyporus adustus.

regions were chiefly found in the sapwood and heartwood of the upper part of the stump but did not reach its upper surface.

Symptoms of Class 3 were usually present and extensive, especially in heartwood. Sometimes, in the absence of the tawny regions, Class 3 symptoms extended from near the stump top (next to symptom Class 1) down into the stump. Their upper margins were often adjacent to the tawny regions. In sapwood the symptoms of Class 1 or 2 sometimes (in the absence of Symptom Classes 3 and 4) merged below into the diffuse, light brown discoloration of Sympton Class 5 .

In the sapwood the diffuse gray stain characteristic of Symptom Class 4 was seldom extensive and was often absent. The corresponding symptom in the heartwood (dark olive green stain) differed slightly in appearance from the yellowish green characteristic of normal heartwood in yellow-poplar, and it was often extensive within one-year-old stumps.

Diffuse, light brown discoloration of Symptom Class 5 in sapwood seems to show the first color change induced in freshly-invaded sapwood. It is sometimes difficult to distinguish from the bright white of normal sapwood. In heartwood the purple stain often appeared before the brown or tawny symptoms, but these seemed not always to follow in previously purple-stained tissues. The purple stain of heartwood is characteristic of wounded yellow-poplar, sometimes referred to as "blue-butt" when it occurs extensively near basal wounds (Roth, 1950). A similar discoloration develops in sapwood. 


\section{Incidence \\ (cumulative)}

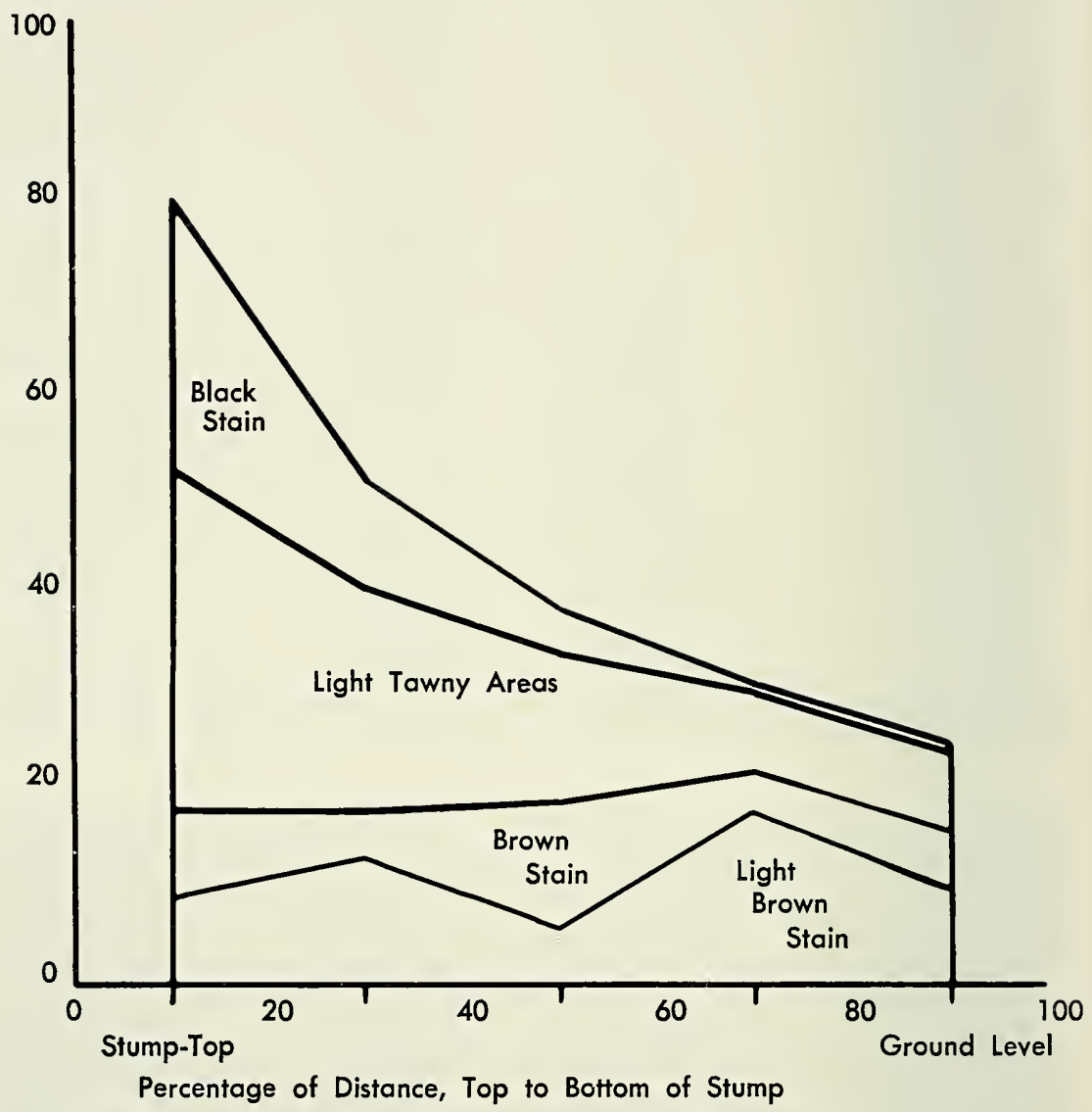

Cumulative incidence of different sapwood discolorations at isolation points

FIGURE 9 (Graph 2). Cumulative incidence of different sapwood discoloration classes as recorded at isolation areas grouped by $20 \%$ percentage classes of the total distance from stump top to soil line.

\section{FUNGI CHARACTERISTICALLY FOUND AT DIFFERENT DEPTHS IN STUMPS OF SEEDLING SPROUTS CUT THE PREVIOUS YEAR}

It was possible to categorize fungi isolated from one-ycar-old stumps into those which penetrated rather deeply and those found close to the stump top (Figure 10). To the group of superficial invaders (miscellaneous non-woodrot fungi) belong species representing the following genera: Aspergillus, Fusarium (2 species) ; Coniothyrium, Glocosporium (2 species); Penicillium and Trichoderma. Five basidiomycetes (the five 

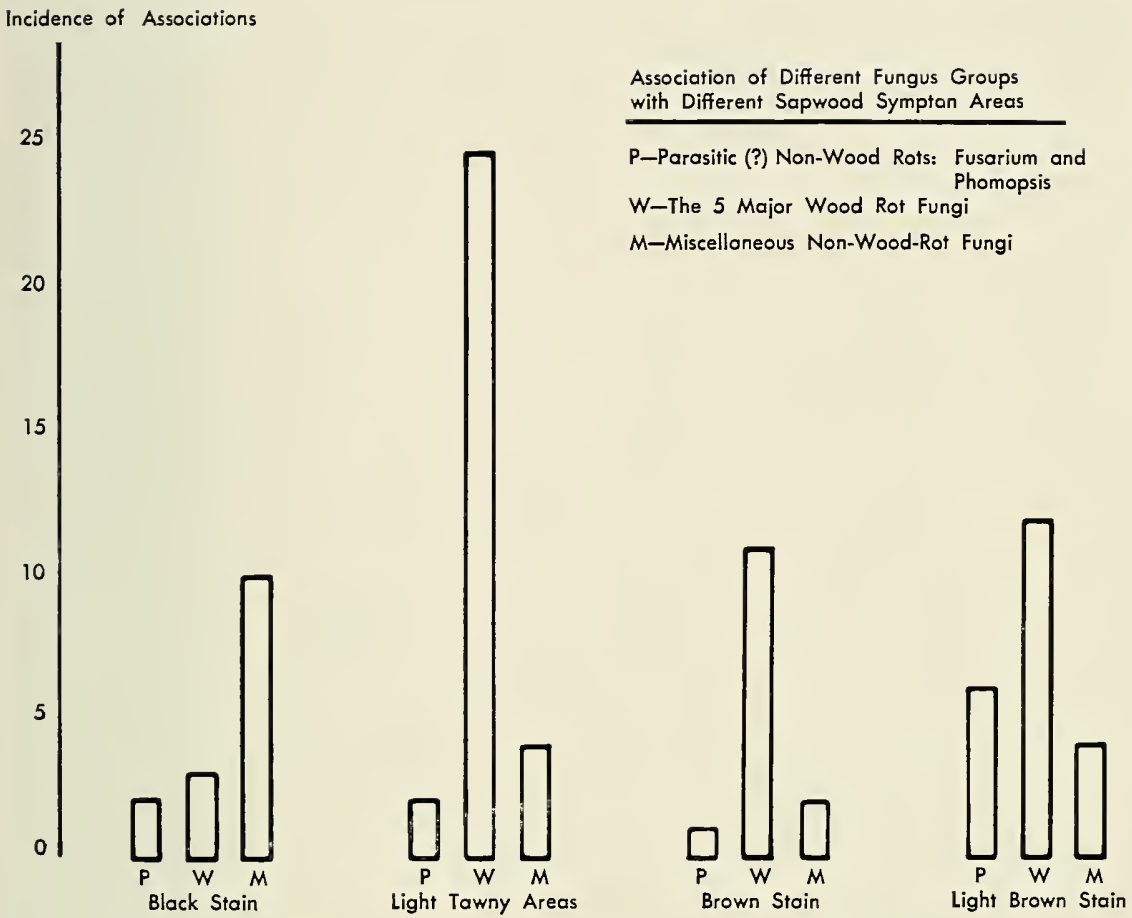

FIGURE 10 (Graph 3). Association of different fungus groups with each of 4 major sapwood symptom areas. Phomopsis sp. and Fusarium sp. \#l are together designated as group $P$., the five major wood-rotting basidiomycetes designated $W$, and miscellaneous nonwood-rotting fungi as $M$. The height of the columns represents the incidence of different recorded fungus-symptom associations.

major woodrot fungi), Peniophora sp., Polyporus adustus, Polyporus versicolor, Pleurotus ostreatus and Stereum purpureum, had all penetrated deep within the stump. Penetrating less deeply were a species of Fusarium and a species of Phomopsis (Figure 11). Of these the Fusarium sp. was abundant below the stump tops, and its incidence appeared to decrease gradually at greater depths. The species of Phomopsis, by contrast, was most frequently isolated from well below the middle of the stump. All five basidiomycetes penetrated more deeply than the Fusarium or the Phomopsis species. All isolations were made using $12.5 \mathrm{~g} / 1$ malt-agar as recommended by Nobles (1948). Nonbasidiomycetes were identified by H. L. Barnett.* Basidiomycetes were first placed in homegeneous numbered groups. Several samples from most of these groups were identified by

*H. L. Barnett is Chairman of Department of Plant Pathology and Bacteriology, West Virginia University, and Mrcologist in the West Virginia University Agricultural Experiment Station. 
Incidence

10

8

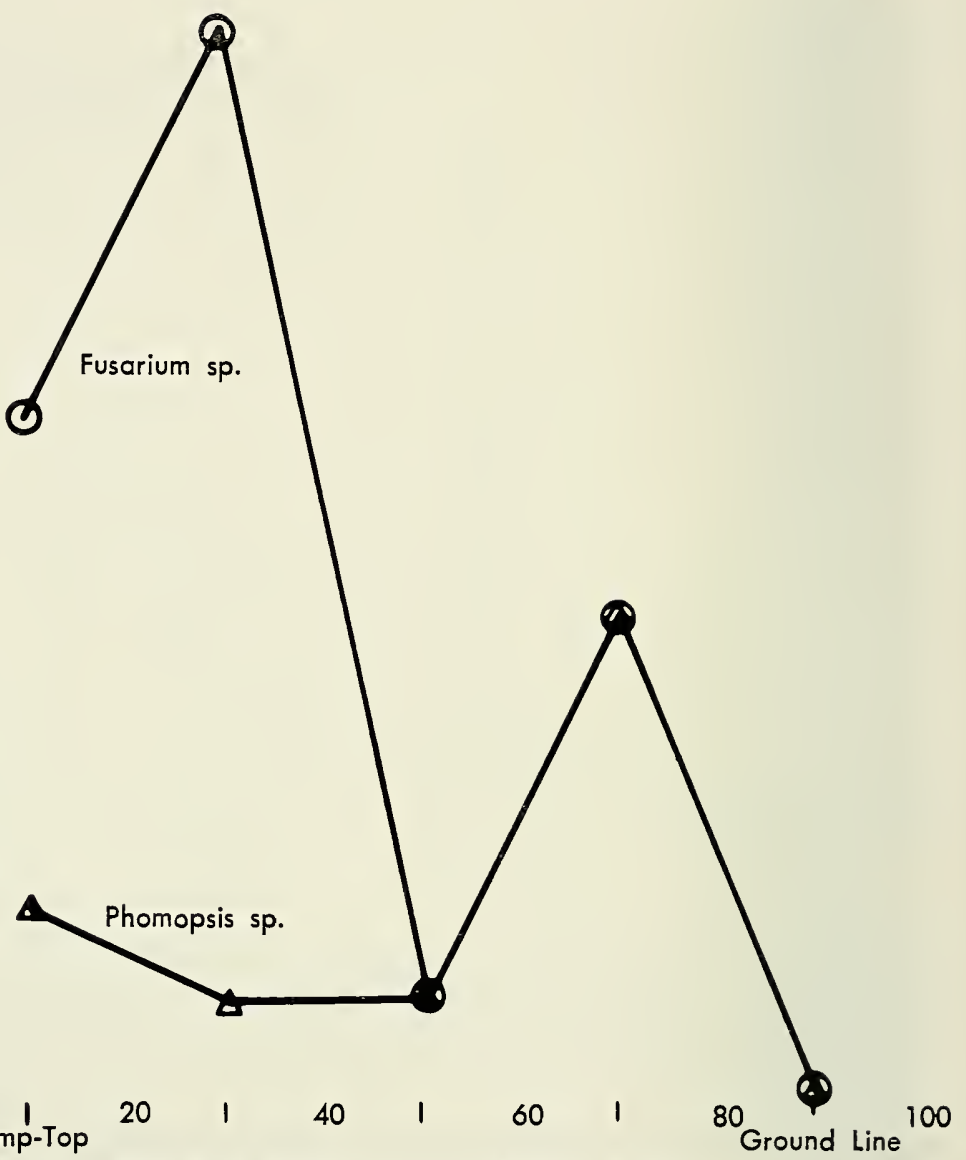

Percentage of Distance, Top to Bottom of Stump

Incidence of 2 Non-Wood-rot fungi at isolation points

FIGURE 11 (Graph 4). Incidence of Fusarium sp. \#1 and of Phomopsis sp. as recorded at isolation areas, grouped by $20 \%$ percentage classes of the total distance from stump top to soil line.

Frances Lombard or Dr. Len of the U. S. Department of Agriculture fungus identification laboratory, then at Beltsville, Maryland.

Three of the five basidiomycetes, Peniophora sp., Polyporus adustus and Polyporus versicolor were distributed in a pattern much like that of the penetrating Fusarium species, being found frequently at the stump top and decreasing with increasing depths. Pleurotus ostreatus followed this same pattern but was less abundant. Steven purpureum, like

16 


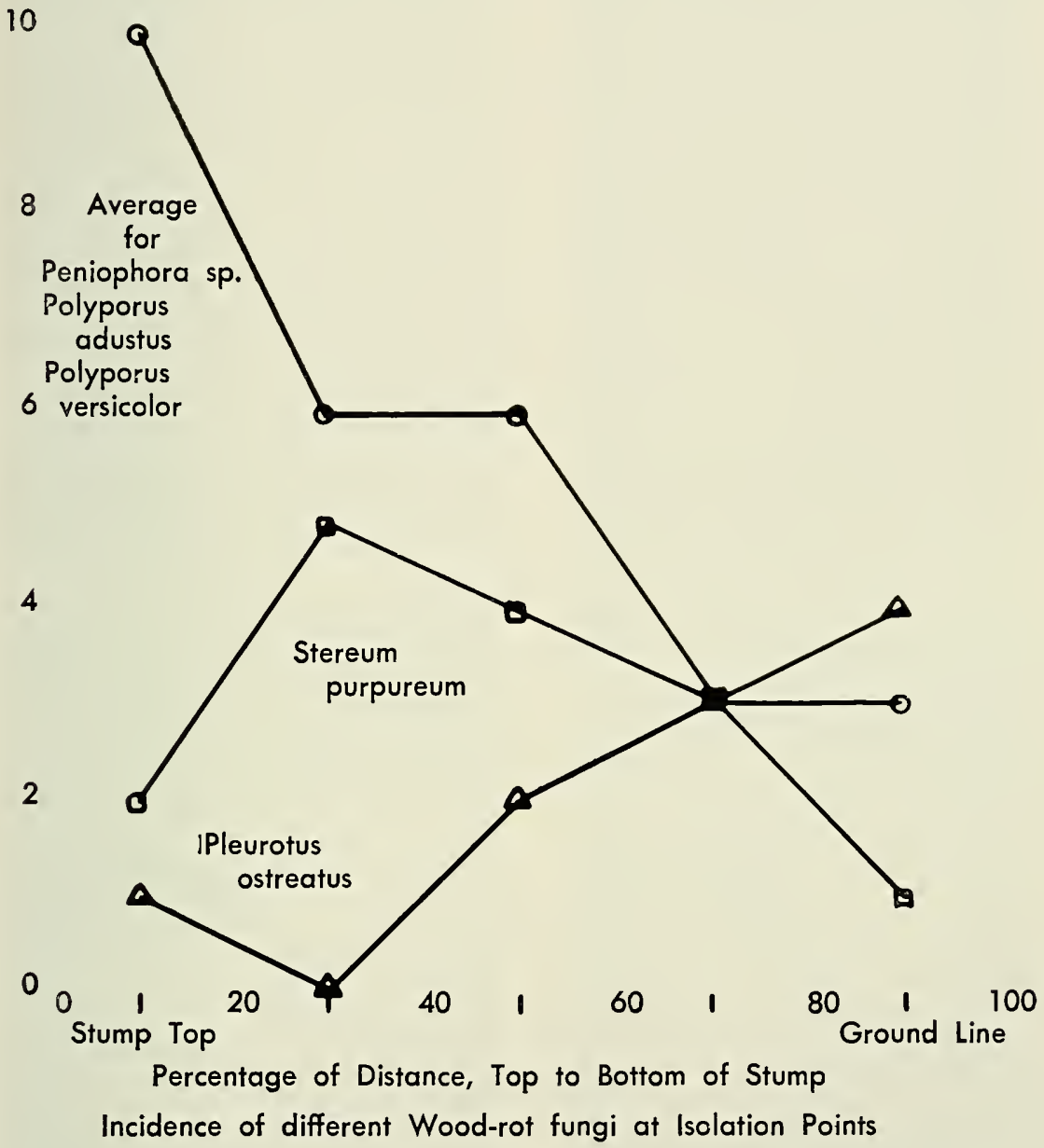

FIGURE 12 (Graph 5). The combined average incidence of three common woodrotting basidiomycetes (Peniophora sp., Polyporus adustus and Polyporus versicolor) as recorded at isolation areas, grouped by $20 \%$ percentage cla ses of the total distance from stunip top to soil line as contrasted with camparable figures for the average incidence of Stereum purpureum and of Pleurotus ostrealus.

Phomopsis sp., was more often found deep within the stump and was the fungus most often found close to the ground line (Figure 12).

The Fusarium sp. and four basidiomycetes lived and grew within the upper part of the stump and penetrated downward effectively. Of the nonbasidiomycetes only the Fusarium sp., and Phomopsis sp. were found deep within the stump. The Stereum sp. and Phomopsis sp. were both. most often found within the living basal part of the stump. 


\section{FUNGI ISOLATED FROM SPECIFIC REGIONS OF DISCOLORATION AND DECAY}

Cultures made from isolation areas showing the symptoms just described demonstrated that the distinct discoloration and/or decays found in these stumps were not associated exclusively with the presence of a single characteristic fungus. Individual fungi and combinations of two or more fungi were isolated from a single isolation area situated within a single symptom region, as well as from isolation areas that bridged the transition between symptoms (Appendix Table 2). Another isolation area selected within the same or a similar symptom region, even in the same stump, sometimes yielded different organisms.

The association of each fungus isolated with the symptom or symptoms characterizing the isolation area is shown in Appendix Table 3. Thirteen nonbasidiomycete species and six basidiomycetes were isolated. Sapwood was more adequately sampled than heartwood. Eighty per cent of the fungus isolations made from the heartwood yielded basidiomycetes, and basidiomycetes were isolated from nearly 60 per cent of the isolations made from sapwood. It is clear that although the number of different nonbasidiomycetes was more than twice the number of different basidiomycetes isolated, and although the nonbasidiomycetes isolated from the sapwood were numerically and proportionally greater than from the heartwood, most of the isolations yielded one or more of six wood-decay basidiomycetes.

Taking into consideration the combinations of fungi isolated when two came from the same isolation point (Table 1 ), it is evident that different basidiomycetes were sometimes found in paired association when the isolation point involved either one or two symptoms. Only two nonbasidiomycetes were isolated more than once in paired combination and then always with a basidiomycete. Fusarium sp. no. 1 was isolated nine times in combination with basidiomycetes; three times each with Peniophora sp., Pleurotus ostreatus and Polyporus adustus. Phomopsis sp. was paired twice with Polyporus versicolor and twice with Peniophora sp. Peniophora sp. was also found three times in combination with Polyporus adustus-the only basidiomycete with which it occurred in combination. Pleurotus ostreatus, isolated three times with Fusarium sp. no. I, was never isolated with a basidiomycete. Polyporus adustus was associated in paired isolation only with Fusarium sp. no. 1 or Peniophora sp. Polyporus versicolor was never isolated with any other basidiomycete but occurred twice in combination with Phomopsis sp. Sixteen two-fungus isolations occurred involving six fungi commonly isolated (Table 2). Two of the six were nonbasidiomycete species of Fusarium and Phomopsis. Four were 

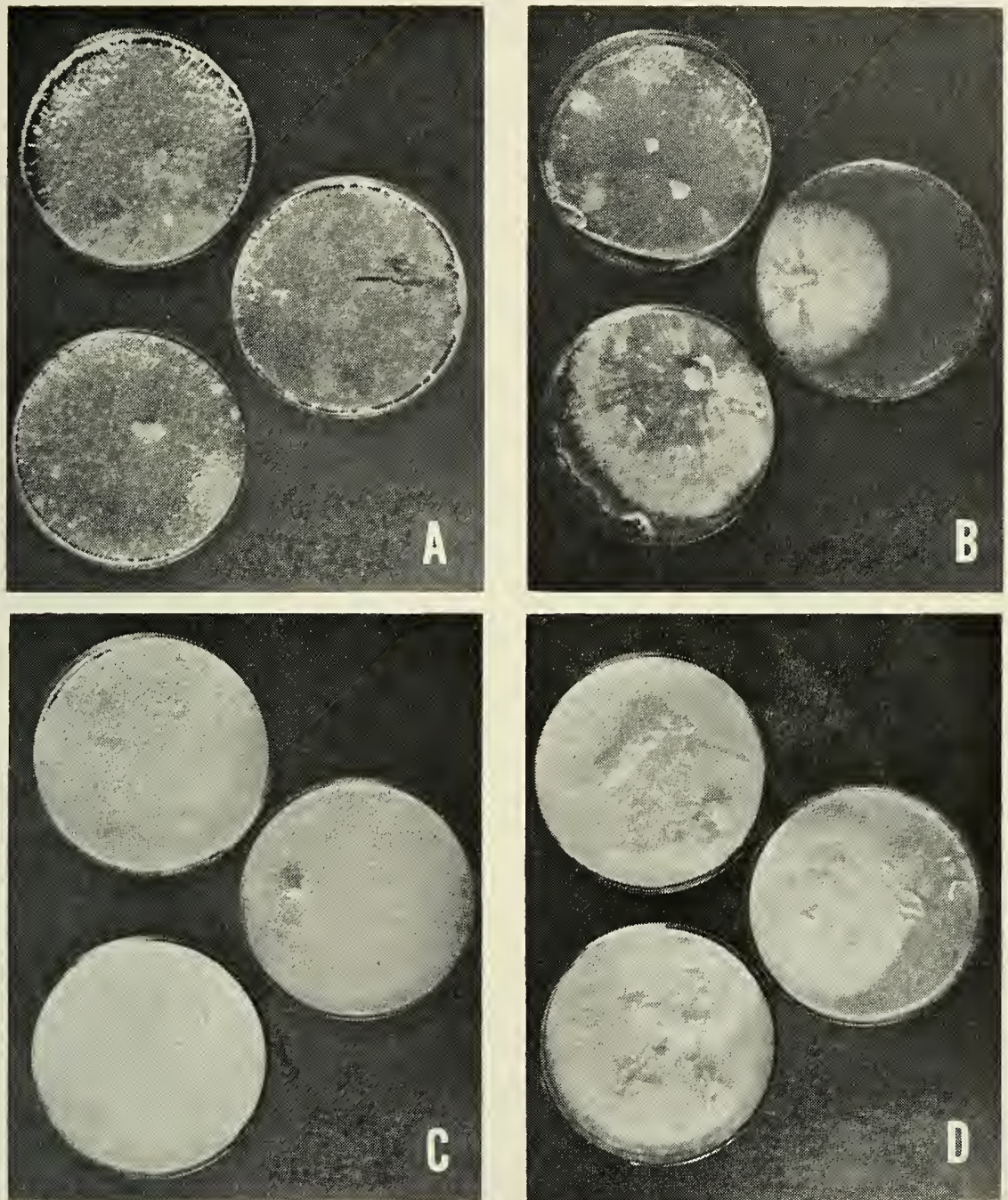

FIGURE 13. Six-week-old cultures of four wood-rotting basidiomycetes commonly isolated from stumps cut one year previous to examination and culturing. All cause white rots of the sapwood. None appear to invade the buts of adjacent elite stems. 13-A is Peniophora sp; 13-B is Pleurotus ostreatus; 13-C is Polyporus adustus; 13-D is Polyporus versicolor.

basidiomycetes Peniophora sp., Pleurotus ostreatus, Polyporus adustus and Polyporus versicolor. The theoretical distribution in randomly paired association of two members of one class and four belonging to a second class as derived from a six-membered two-way table would yield one pairing between members of the two-membered class (nonbasidiomycetes, 


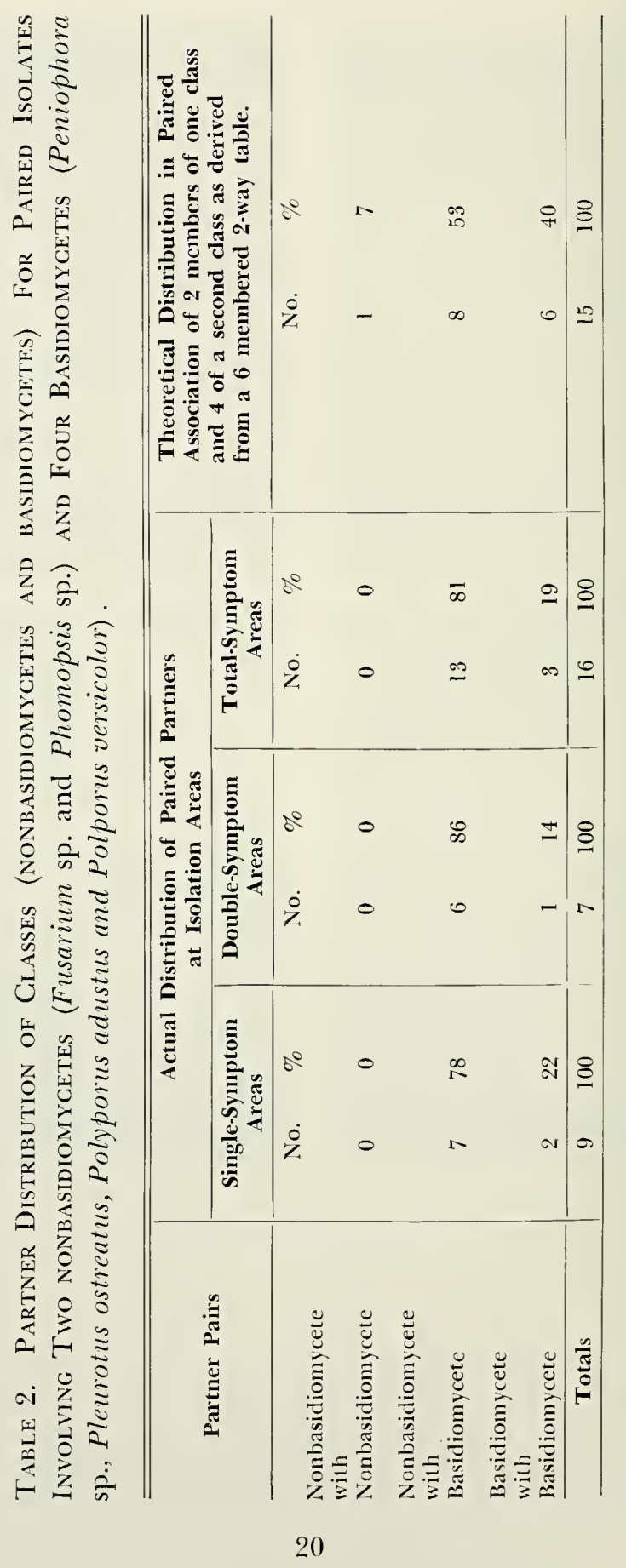


in this case), six pairings between members of the four-membered class (basidiomycetes), and eight pairings involving one member of each class. In the case of the 16 actual pairings found the corresponding figures were 0,13 , and 3 , respectively. This suggests that facts involved in the situation under study favored the pairing of basidiomycetes with nonbasidiomycetes.

\section{SOFTENING OF THE WOOD ASSOCIATED WITH THREE SAPWOOD SYMPTOMS AND THE FUNGI ISOLATED}

A measure of the comparative softening of the wood in specified symptom areas was obtained by compressing the symptomatic wood with a spring-testing device. A standard pressure of $50 \mathrm{lbs} / \mathrm{square}$ inch was locally applied to a small portion of the split surface showing the symptom for a short standardized time period. The results are expressed as relative values. Tests were made at three different places within each symptom region opposite an isolation area but each time far enough away from previous test sites to give readings uninfluenced by previous testing. The resulting depressions in the wood, measured in thousandths of an inch, were recorded and averaged. Average readings were regarded as usable only if all three readings for the symptom region were closely comparable. Some of the variation among average values for the same sympton class may be due to variation in the depth of the symptom type shown at the surface, and some to the lack of uniformity due to the alternating layers of spring and summer wood. Only the three most prominent types of symptom classes of the sapwood (2,3 and 5) could be adequately measured in this way.

Figure 14 shows values from ten measurements of softness of sapwood symptom No. 2 (light tawny regions) and the fungi isolated from each tested symptom region. Nine such measurements and corresponding isolation records are shown for sapwood symptom No. 3 (dark brown stain) and 11 for No. 5 (diffuse light brown discoloration). It is clear that the wood of the light tawny regions was often, but not always, softer than that in the other two symptom regions. However, the range of values in 3 and 5 is considerable, and the wood showing symptom 3 seems usually to have been harder than that showing symptom 5, although the lat ter is found deeper within the stump. Wood-rotting basidiomycetes were isolated from the hardest as well as from the softest wood tested. Polyporus versicolor seems especially rersatile in this regard. It is interesting to find two instances where Fusarium sp. No. 1 was the only fungus isolated from tissues somewhat softer than some from which basidiomycetes were isolated. Fusarium sp. No. I was also isolated three times in combination with basidiomycetes from moderately soft wood. 


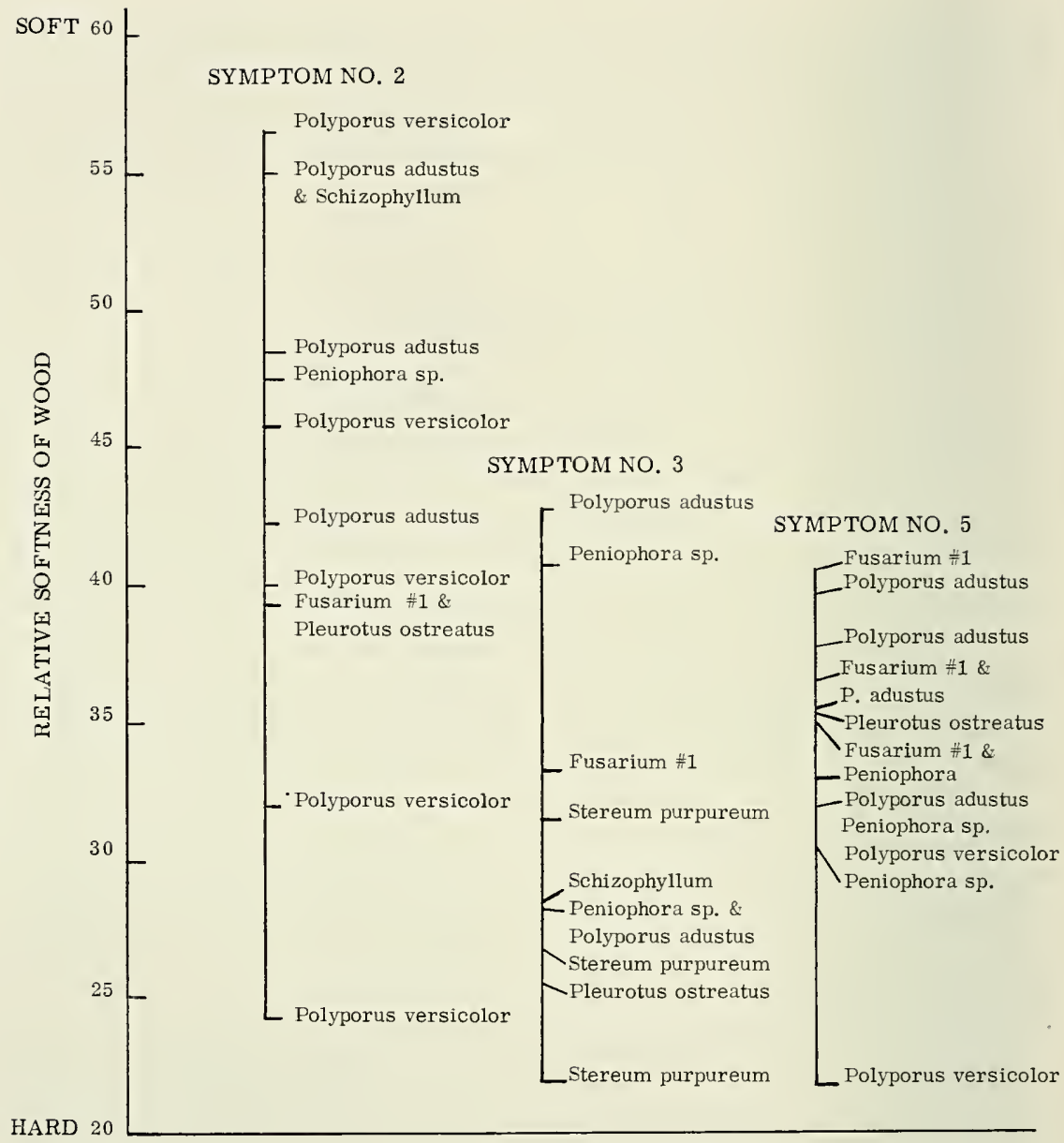

FIGURE 14 (Graph 6). Values obtained from measurements of softness of the sapwood showing: a light tawny discoloration (Class 2 symptom), dark brown stain (Class 3 symptom) and diffuse light brown discoloration (Class 5 symptom) together with the species of fungi isolated from wood characterized by each softness test.

Perhaps some of the different symptoms represent stages in the development of others. Such cases might represent successive stages of softening of the wood by the same fungi or groups of fungi. The extreme variation in wood softness for sapwood symptom 2 and the association of Polyporus versicolor with rood showing all degrees of hardness for this single symptom suggests that this is not always the case. Different symptoms often yielded many of the same fungi so that the symptoms, and perhaps the softening, resulted from the action of two or more organisms acting simultaneously or in succession. 


\section{Discoloration, Decay and Disintegration Of Wood in Stumps and Stump Sprouts}

Studies reported in this chapter were made in 1963 and 1964 on the property of the Morgantown Airport (Byler and True, 1966). The in. vestigation involved stumps of yellow-poplars whose stems were cut for mine props 14 and 18 years earlier. A few larger stumps in Coopers Rock Forest which had been cut 22 years previously were also used.

\section{THE DISAPPEARANCE OF WOOD FROM THE AGING STUMP AND FROM ITS ROOT SYSTEM}

Many fungi infect the cut surfaces of yellow-popular stumps. Some may attack and kill the injured bark near the stump top. Areas of cut or bruised bark below may also be quickly invaded and die (Figure 8-D) . Death of the bark speeds the drying of the adjacent wood, stimulating the development of stain and decay. Conversely the spread of stain and decay fungi within the stump, and particularly in sapwood tissues, may threaten the stump bark from within. Infective organisms that grow down into the stump and spread radially outward may kill the cambium and the bark. Dormant buds, situated within areas of dying bark, die with the bark. Only these stump parts covered by living bark produce stump sprouts.

The rapidity with which a considerable number of dormant buds elongate and produce vigorous, leafy sprouts seems to determine the degree to which the stump will be preserved. Parts of stumps lacking growing sprouts often disappear (Figure 15). The roots just below isolated sprouts survive to provide them with an abundant supply of nutrients and water. Roots or parts of roots not closely associated with any sprout die and disappear.

Roots of 50 stumps cut 14 years previously and showing various degrees of sprouting were dug and examined. Fifty-five per cent of the roots of stumps that had a total sprout basal area of less than 7.2 square inches (Table 3) showed some decay. Sprout clumps with total sprout basal area 7.3 to 14.4 square inches had 10 to 15 per cent of their roots showing decay. Stumps having total sprout basal areas greater than 28.8 square inches had, on the average, less than 6 per cent of the roots decaying. When stumps were arranged by diameter classes (Table 4), the stumps with the fewest sprouts showed the highest percentage of roots decayed.

The living agents chiefly responsible for the disintegration and disappearance of the wood are almost certainly fungi. The fungi surely include those causing white rot and probably some that cause brown rot, 

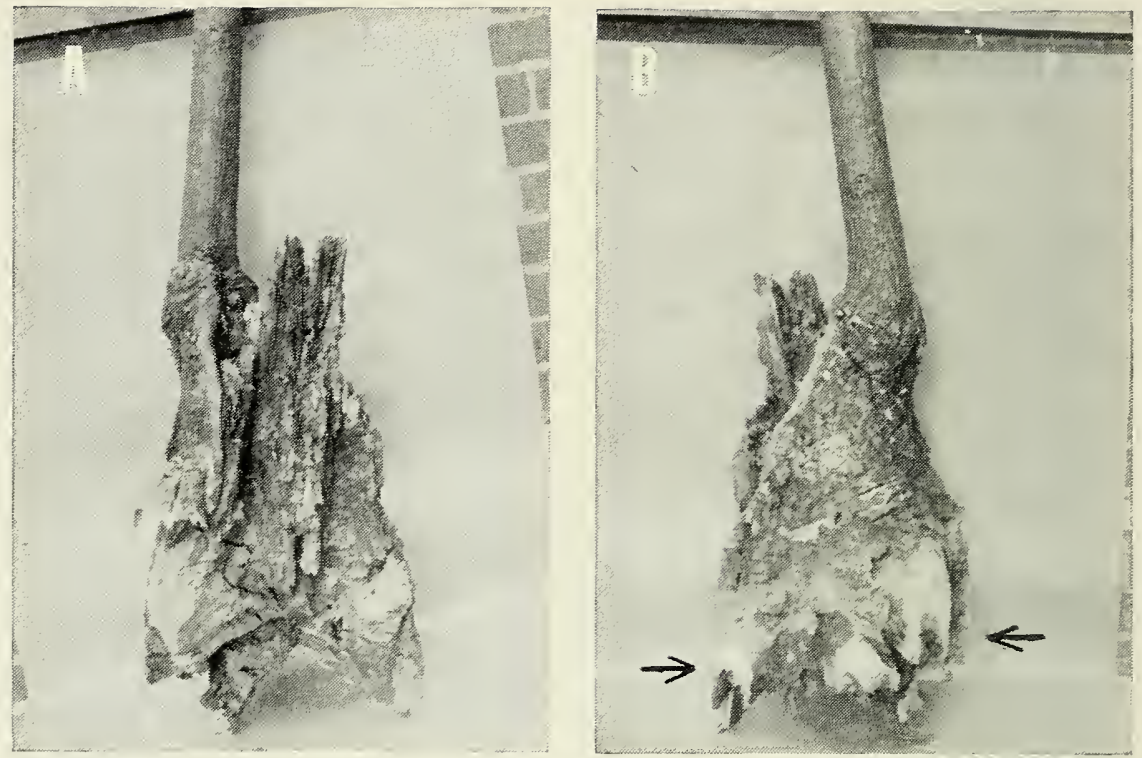

FIGURE 15. Views of a stump with a single sprout showing the loss to decay of those stump and root tissues net functionally related to the sprout. 15-A shows decay of the stump and disappearance of the roots from the side farthest away from the sprout. 15-B shows decay and partial disappearance of those portions of the remaining live root system farthest removed from the sprout.

although the latter are not often reported from yellow-poplar. Soft-rot organisms are isolated from dark stained, and often brash, wood of stumps and defective butts of living trees.

Perhaps the growing sprout protects those tissues nearest to it from decay and disintegration by furnishing carbohydrates, the substances mos: likely to run low among those furnished by the root. The carbohydrates

Table 3. Sprout-basal-area Class of 14-Year-Old Stumps In Relation To The Percentage of Roots Found Decayed

\begin{tabular}{cccc}
\hline \hline $\begin{array}{c}\text { Sprout-basal-area Class } \\
\text { (square inches) }\end{array}$ & $\begin{array}{c}\text { Percentages of } \\
\text { Examined Roots } \\
\text { Found Decayed }\end{array}$ & $\begin{array}{c}\text { Number of } \\
\text { Stumps } \\
\text { Per Class }\end{array}$ & $\begin{array}{r}\text { Number } \\
\text { of Roots } \\
\text { Examined }\end{array}$ \\
\hline $0-7.2$ & 55 & 12 & 44 \\
$7.3-14.4$ & 15 & 7 & 33 \\
$14.5-21.6$ & 10 & 7 & 41 \\
$21.7-28.8$ & 11 & 4 & 19 \\
$28.9-36.0$ & 3 & 6 & 37 \\
$36.1-43.2$ & 9 & 1 & 53 \\
$43.3-50.4$ & 0 & 1 & 15 \\
$50.5-57.6$ & 0 & & 9 \\
\hline
\end{tabular}


Table 4. Percentage of Roots Decayed In Relation to Stump Diameter Within 6 Sprout-clump Basal Area Cilasses for 14-Year-Old STUMPS

\begin{tabular}{ccccccc}
\hline \multirow{2}{*}{$\begin{array}{c}\text { Stump-diameter } \\
\text { Class (Inches) }\end{array}$} & $\mathbf{0 - 7 . 2}$ & $\begin{array}{c}\text { Sprout-basal-area Classes (Square } \\
\text { (I.3-14.4 }\end{array}$ & $\mathbf{1 4 . 5}-21.6$ & $\mathbf{2 1 . 7 - 2 8 . 8}$ & $\mathbf{2 8 . 9 - 3 6 . 0}$ & $\mathbf{3 6 . 1 - 4 3 . 2}$ \\
\hline $14-15$ & $\%$ & $\%$ & $\%$ & $\%$ & $\%$ & $\%$ \\
\hline $12-13$ & - & - & - & - & - & 30 \\
$10-11$ & 130 & - & - & - & 0 & 10 \\
$8-9$ & - & 40 & 14 & 13 & 0 & - \\
$6-7$ & 100 & 22 & 0 & - & 0 & 0 \\
$4-5$ & 42 & 5 & 0 & 0 & 8 & 0 \\
\hline
\end{tabular}

provided by roots come from a limited supply which must soon be supplemented and replenished by the photosynthetic activity of the growing sprouts. But fungi, like yellow-poplar sprouts, use and require both carbohydrates and nitrogen. Fungi within a stump may compete with the growing sprout for both types of organic nutrients. Possibly the sprout can dominate the situation within its own vicinity, but beyond the restricted area of its competing influence the fungi control the situation. The succulence of stump sprouts suggests that nitrogen is abundant. Carbohydrates are more likely to be in short supply, especially within unsprouted portions of the stump. Certainly there is a critical period in the life of a stump during which the respective areas of influence of the growing sprouts and of the wood-decay fungi are determined.

In 14-year-old stumps of this intolerant species, the sprouts seem to be competing with each other chiefly for light. Fungi also invade and destroy tissues of stump and sprout made available to them by the weakening and death of suppressed sprouts.

\section{PATTERNS OF DISCOLORATION AND DECAY IN STUMPS CUT 14, 18 AND 22 YEARS PREVIOUSLY AND IN THEIR RDOTS AND SPROUTS}

\section{Discoloration and Decay in Roots}

Healthy yellow-poplar roots lack the yellowish green central core (heartwood) that characterizes the wood of most yellow-poplar stems more than 3 inches in diameter, and of many that are smaller. A similar appearing discoloration which we shall call pathological heartwood may develop around surface wounds or, under various unusual conditions, within wood which would normally be bright white sapwood. In living trees and in sound stumps, the heartwood tapers toward the ground line 
so that stem tissues there contain little heartwood and healthy roots contain none (Figure 4-B and $\mathrm{C}$ ).

A variety of other discolorations may be found in both sapwood and heartwood of stump and roots. Such discolorations are often associated with wounds and sometimes extend for some distance. Common discolorations in yellow-poplar include brown, blue, and purple stains. Often but not always, the wood of such darkened areas surrounding the pith (Figure 16) is brash, in which case the wood is considered decayed. When brash or decayed wood is pried up with the point of a knife blade, very soft tissues break across the grain at the edges of the knife blade, or shorter splinters are obtained than when sound wood is similarly probed. When discolored tissues are shown to be sound by the splinter test described above, the discoloration is referred to as stain or discoloration, but not decay. Such discoloration may represent a beginning (incipient) stage in the development of decay. Discolored tissues may, however, remain sound.

When 50 fourteen-year-old stumps were dug to permit an investigation of their roots, 283 roots greater than 2.5 inches in diameter at the stump were examined and 42 were found to contain decay.

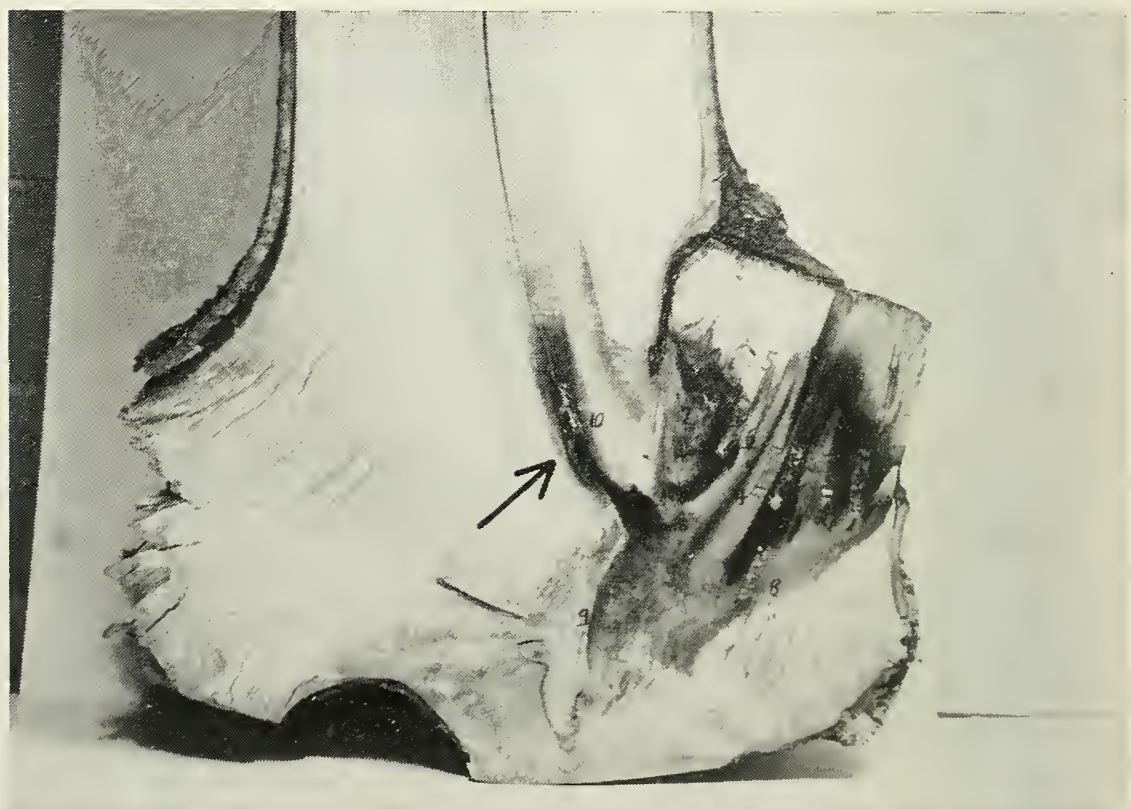

FIGURE 16. Scction through the ba $e$ of an elite stem and the stump of an ancillary stem removed in thinning the clump. Note the dark discoloration of that portion of the heartwood surrounding the pith of the elite stem and its origin within the stump of the sprout removed in thinning. 
Eighteen roots were only partially pesent, having lost by previous decay those tissues functionally farthest remored from the nutritionally supporting sprout (Figure 15-B). A blue-stained zone of mechanically sound wood usually bordered the normal tissues next to the wounds created by the disintegration of root tissues. The origin of this now inactive decay could not be ascertained, but adjacent stump tissues were often also involved. Such decay never extended to or from the distal ends of the roots.

In ten roots the decay had clearly originated within the heartwood of the stump. As this decay spread downward, the tissues of sapwood areas in stump and root were first converted into mechanically sound yellowish green pathological heartwood. Within these downward spreading discolored areas, a central white rot usually developed (Figure 17). A similiar pattern characterized an occasional radially outward extension of pathological heartwood (often followed by decay) from the stump heartwood into the peripheral sapwood. In a few cases the bases of sprouts still lacking heartwood were invaded by pathological heartwood of stump origin, although decay was not found in the sprouts examined.

Five roots had a spreading white rot of the surface sapwood only (Figure 18). This type of decay also always involved surface tissues of the basal parts of the stump. Armillaria mellea was isolated from this surface sapwood rot. Two roots contained both the central and the surface rots, and seven were completely decayed.

Within 19 sound roots some pathological heartwood was present. In each case it was found below an adjacent area of rot within the parent stump.

Nearly all decay observed in the roots of these stumps seemed to have arisen from within the stump or at the root crown. The death and decay of yellow-poplar sprouts, therefore, seems to depend chiefly upon what happens above ground. Root decay did not appear to precede the death or decay of sprouts dependent upon them. No relationship was found between the percentage of roots decayed and the percentage of sprouts decayed per stump (Appendix Table 4).

\section{Discoloration and Decay in Stumps and Sprouts}

Of 496 sprouts examined from stumps of all three age groups, 190 (38 per cent) showed butt rot. Eighty-four per cent of the 190 butt-rotted sprouts were found to have been infected from clecayed areas in the parent stump. Most of the remainder seenred to have become infected through basal wounds, dead branches, or dead companion sprouts from the same stump. 


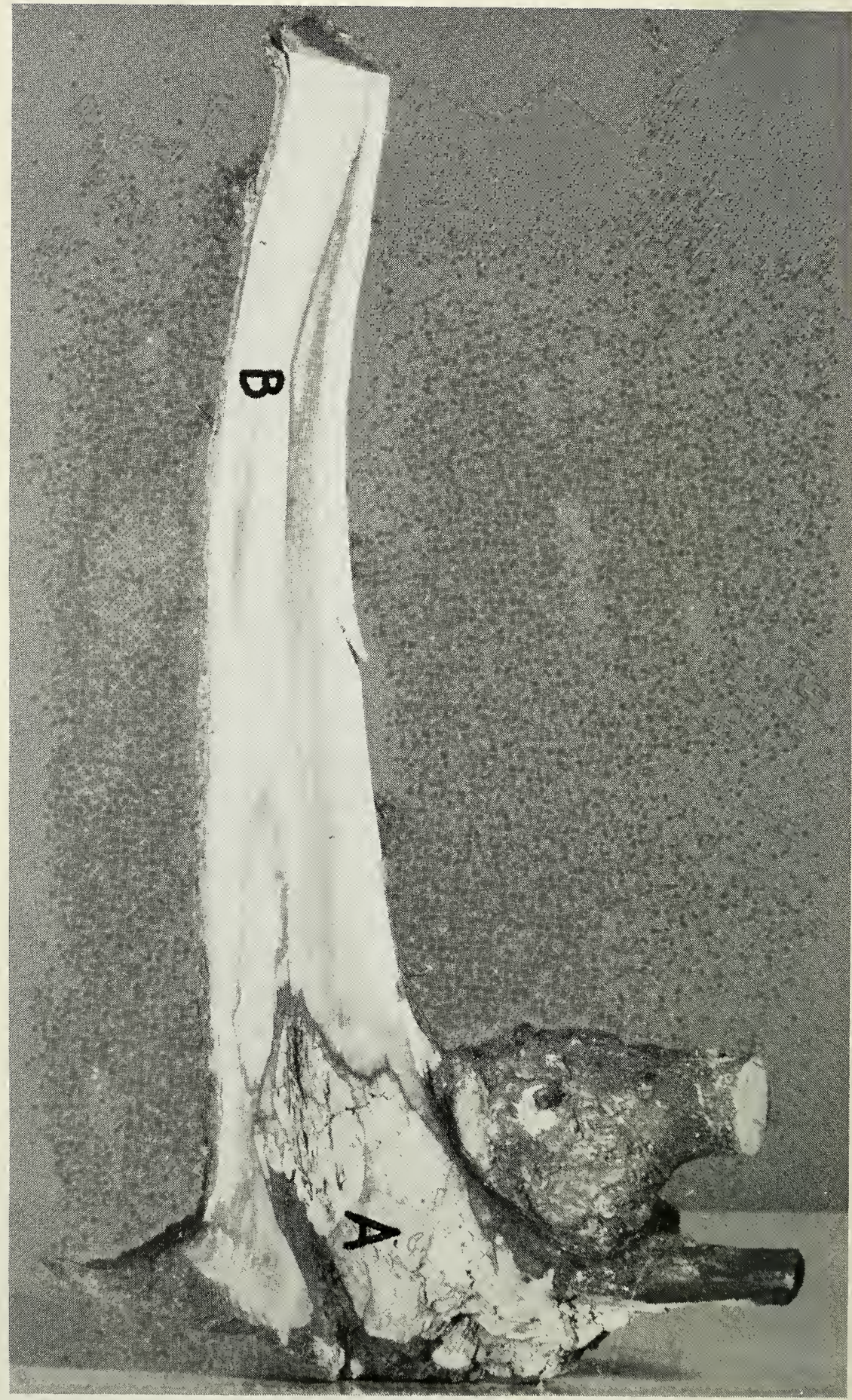


FIGURE 17. Section through a yellow-poplar root close to its union with the stump. The part of the root nearest the stump is decaying with white rot at A. A pathologicalheartwood type of discoloration extends into the affected root for a considerable distance in advance of the decay at B. Normally all root wood of yellow-poplar is clear white sapwood.

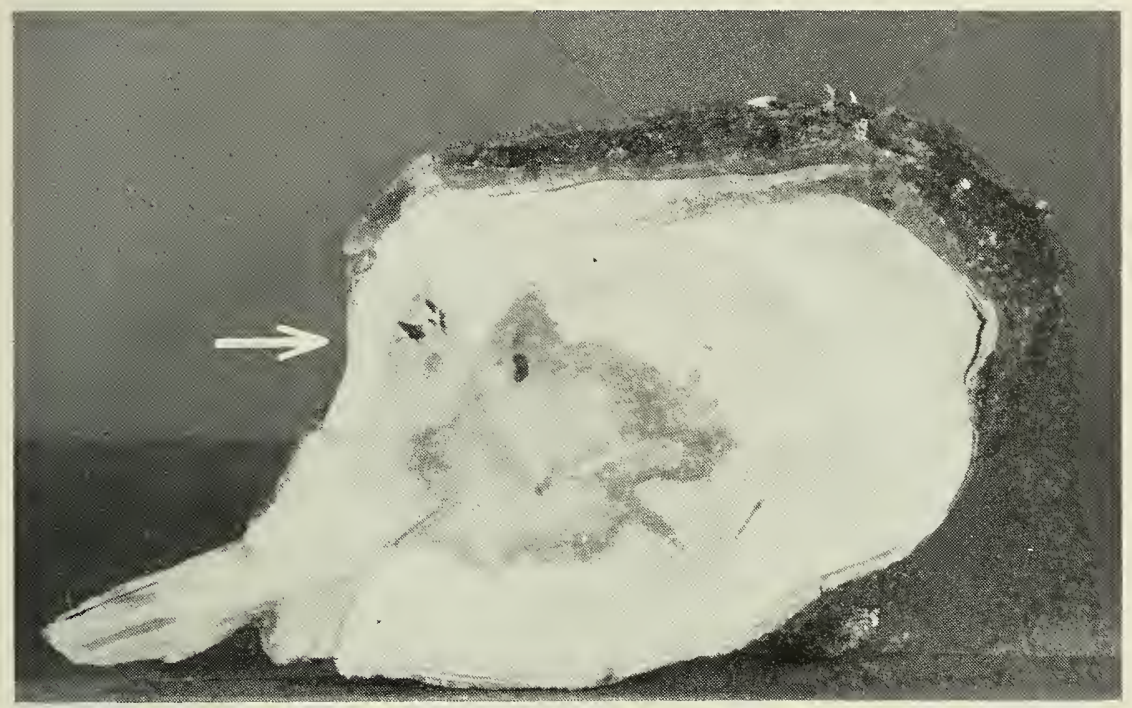

FIGURE 18. A white rot has developed in the surface sapwood of this root close to its union with the stump. No heartwood involvement is evident. Armillaria mellea was isolated from the affacted sapwood.

$A$ heartwood or pathological heartwood connection was always established before butt rot of stump origin entered the sprout. Seventyfour per cent of the 334 sprouts of 14-year-old stumps and 94 per cent of the 162 sprouts from stumps of the older age groups showed this connection. Heartwood in yellow-poplar sprouts is usually initiated at a node 2 or 3 feet above their point of origin on the parent stump. After it is so initiated, it spreads both upward and downward. In its downward development it usually comes to fuse with the heartwood of the parent stump.

\section{The Nature of Butt Decay Found in Stump Sprouts}

All butt rot found in sprouts from 14-year-old stumps consisted of a brashness of tissues near to and centered at the pith. Brash wood, and sometimes the sound wood adjacent, was variously dark colored with a blue or purple discoloration often predominating (Figure 4-A and 16). 


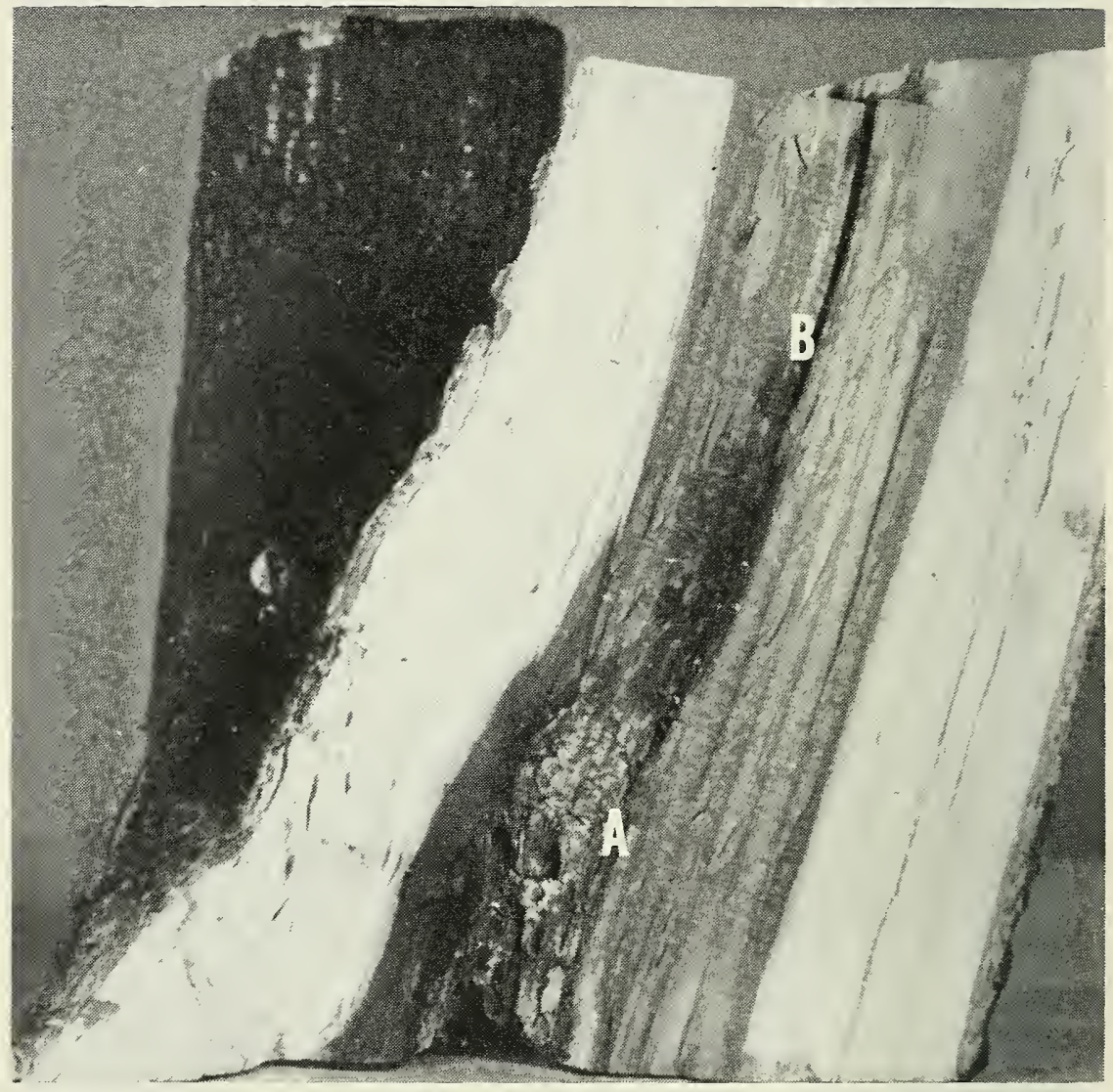

FIGURE 19. A section through the decaying butt of a sprout affected by white rot at $A$ (Below, mostly to the left of the pith) and by the pith-centered Margarinomyces-type rot at $\mathbf{B}$ (above.)

From this type of decay, Margarimomyces sp. and other nonbasidiomycetes were frequently isolated. We refer to this decay as the Margarinomyces-type rot.

In 32 sprouts of 162 examined from the 18 and 22 -year-old stumps, only the Margarinomyces-type rot was found. Trenty others contained a white rot from which Armillaria mellea was isolated. Both types of rot sometimes occurred on the same sprout. In five instances the white rot was found within the outer heartwood, while the brash tissues of the Margarinomyces-type rot were (as usual) confined to the inner heartwood near the pith. Both types of decay were usually limited to the sprout base. The white rot was never found more than a foot above the point of sprout origin (Figure 19), although it always appeared to be spreading. 
Factors Favoring the Incidence of Butt Rot in Sturnp Sprouts

Sprouts originating high on the stump were most often decayed (Figure 20-A). Nearly all sprouts originating two or more inches above the soil line on stumps cut 14 years earlier contained some butt decay. Generally speaking, in this aged population the larger sprouts were most likely to have completed heartwood connection with the parent stump (Figure 21). Larger sprouts were more likely to be decayed, therefore, than smaller sprouts in this age-group. High-origin sprouts were also often the larger sprouts (Appendix Table 5) although all sprouts from a stump are considered to be the same age.

Sprouts from the larger stumps in the 14-year-old group had a higher incidence of butt rot than did equal-aged sprouts from smaller stumps. Among the older stumps (cut 18 and 22 years) 5 of 6 exceeding 16 inches in diameter had at least one decayed sprout, although only four of 25 similar-aged stumps of smaller diameter had any sprouts with butt rot.

Decay Spread Faster Through the Stems of Sprouts with Suppressed Crowns

Although decay incidence was positively correlated with sprout diameter in this study, decay spread more rapidly within sprouts having

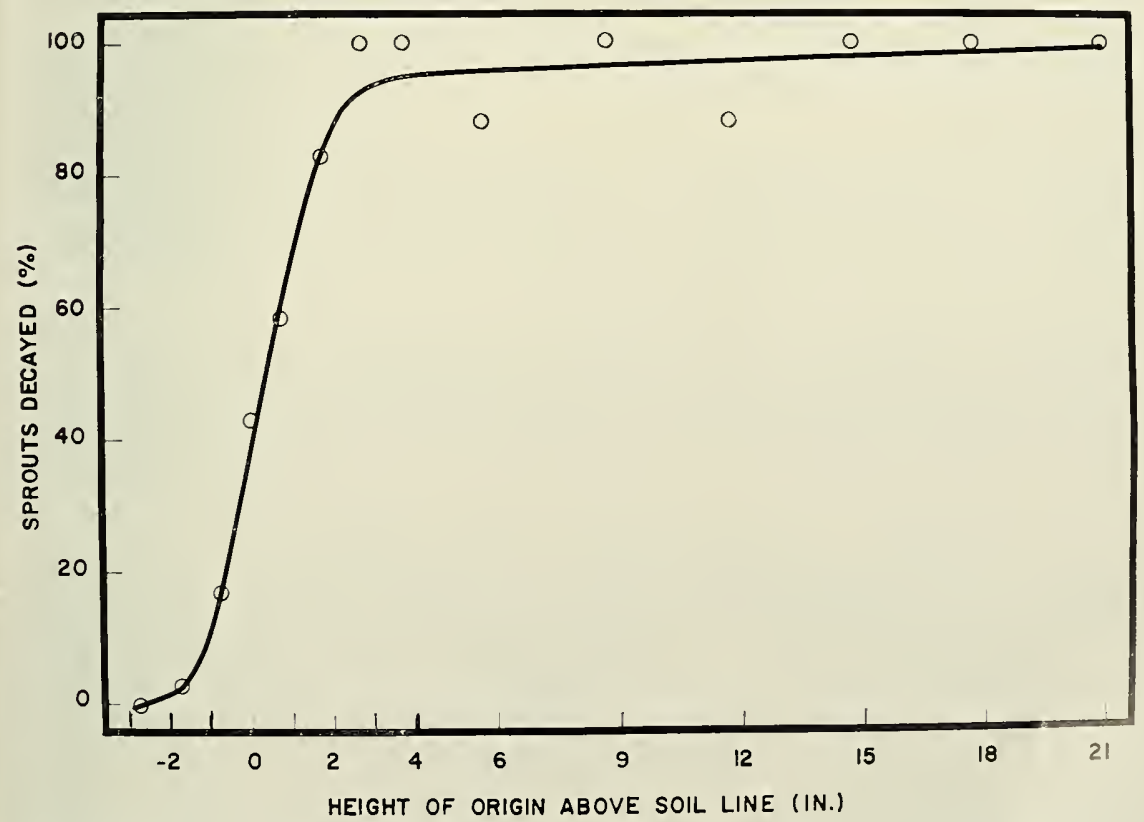

FIGURE 20. The percentage of sprouts decayed as related to the height of their origin. 


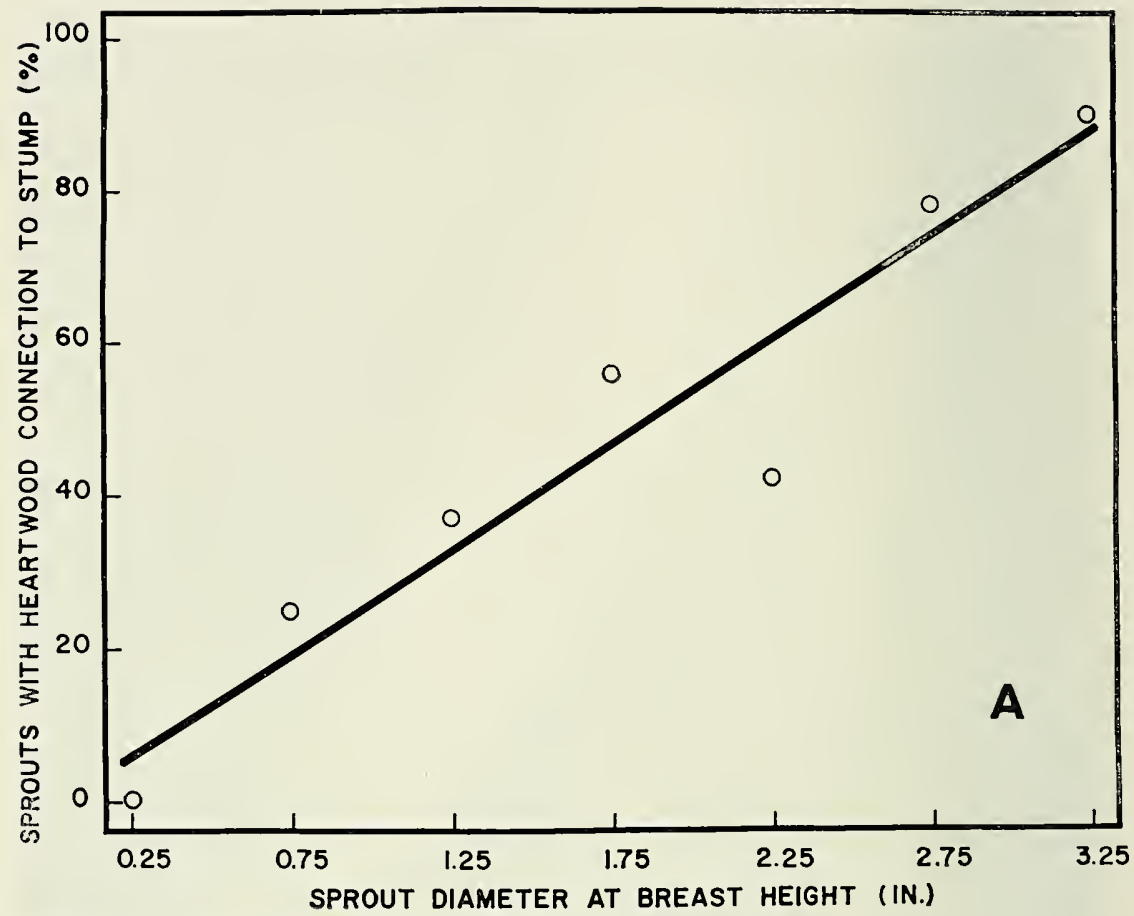

FIGURE 21. The percentage of sprouts having a heartwood connection with the parent stump as related to their diameter.

suppressed crowns once it crossed the completed heartwood connection (Table 5). As the heartwood connection develops late in suppressed sprouts, the 15.7 value for them represents a faster rate of spread than that characteristic of other crown classes.

Organisms Isolated from Representative Samples

Two-thirds of the isolations attempted from roots, stumps, and live sprouts yielded bacteria. More information than is now available is

Table 5. Average Height of Rot in Relation to Sprout Crown Class for 14-year-old Sprouts

\begin{tabular}{lcc}
\hline $\begin{array}{c}\text { Sprout } \\
\text { Crown Class }\end{array}$ & $\begin{array}{c}\text { Average } \\
\text { Height of Rot } \\
\text { (inches) }\end{array}$ & $\begin{array}{c}\text { Number of Sprouts } \\
\text { with Decay }\end{array}$ \\
\hline Dominant & 14.0 & 4 \\
Codominant & 14.6 & 58 \\
Intermediate & 7.8 & 23 \\
Suppressed & 15.7 & 15 \\
\hline
\end{tabular}


needed concerning the part played by those organisms found in the wood of living trees (Basham and Taylor, 1965; Hartley, Davidson and Crandall, 1961; McCreary, Cosenza and Shigo, 1965) and in forest products (Elwood and Ecklund, 1959). The fungi isolated in this portion of the study are listed in Table 6 . These organisms were chiefly responsible for the decay found.

Nonbasidiomycetes in addition to the Margarinomyces sp. were isolated from the Margarinomyces-type rot. Armillaria mellea was chiefly obtained from or near the edge of the white rot. Unidentified basidiomycetes may be responsible for some of this type of decay since they and not Armillaria mellea were isolated from the white rot invading the roots from the stumps. Although Armillaria mellea was not isolated from these tissues, it may have been present. This organism, known to cause a

Table 6. Number of Isolations and Source of Fungi Obtained from SAMPLES

\begin{tabular}{|c|c|c|c|c|c|}
\hline \multirow[b]{3}{*}{ Fungus } & \multirow[b]{3}{*}{ Stumps } & \multirow[b]{3}{*}{ Roots } & \multicolumn{2}{|c|}{ Isolation from: } & \multirow[b]{3}{*}{$\begin{array}{c}\text { Total } \\
\text { Iso- } \\
\text { lations }\end{array}$} \\
\hline & & & \multicolumn{2}{|c|}{ Live Sprouts showing: } & \\
\hline & & & $\begin{array}{c}\text { Margarinomyces } \\
\text { Type Rot }\end{array}$ & $\begin{array}{c}\text { White } \\
\text { Rot }\end{array}$ & \\
\hline Margarinomyces sp. & 2 & 10 & 23 & 2 & 37 \\
\hline Armillaria mellea & 4 & 3 & 0 & 6 & 13 \\
\hline Cephalosporium sp. & 3 & 0 & 7 & 0 & 10 \\
\hline Fusarium sp. & 1 & 1 & 3 & 1 & 6 \\
\hline $\begin{array}{l}\text { Trichoderma sp. } \\
\text { Unidentified }\end{array}$ & 1 & 1 & 4 & 0 & 6 \\
\hline basidiomycetes & 3 & 4 & 6 & 0 & 13 \\
\hline Other fungi & 3 & 1 & 7 & 0 & 11 \\
\hline
\end{tabular}

white rot of both heartwood and sapwood, was not isolated from samples taken from brash dark-stained areas. The two decays found are distinctly separate and seem to be independent. Factors favoring decay seem to favor both kinds.

\section{Part A, Butt Rot in Stems Selected for Crop Trees (Elite Stems) of Thinned Sprout Clumps}

\section{STUMPS OF STEMS REMOVED IN THINNING AS INFECTION} COURTS FOR BUTT ROT OF ELITE STEMS

Non-wounded yellow-poplar sprouts may become infected by butt rot fungi through the parent stump. Infection may also occur following 
the removal of living ancillary (inferior, non-crop) stems in thinnings designed to increase the growth rate or to improve the quality of the elite stem chosen to become the crop tree. The life of such elite stems is expected to be sufficiently long to permit them to grow to a large diameter and to be harvested for high-value lumber or veneer logs.

The work reported in this section was undertaken to explore the possible importance of the part played by butt rot in destroying or devaluating the butt logs of such trees. The results recorded in Part A, however, were observed only fire and eight years after thinning. These results cannot furnish definite information concerning the degree to which either the incidence or extent of decay observed might subsequently have increased during the much longer time required for the elite stems to develop into large-diameter crop trees.

This study has dealt almost exclusively with decay incidence. Some ideas concerning the possible extent to which decay present in the butts of these young crop trees might be expected to spread before their harrest as large-diameter products may be obtained from the scanty published information based mainly on other species. Only a study of butt decay in yellow poplar sprouts older than those which were used in this research can give adequate answers regarding the spread of butt decay within trees of this species.

Hepting (1935) found Armillaria mellea to be one of several "weakly or nonparasitic fungi found causing decay behind fire scars, but extending little or not at all above the scars." Hepting and Hedgcock (1937), in a table showing the relation of butt cull percentage to tree diameter for tree populations with and without basal injuries, showed that yellow-poplars lacking basal wounds areraged no more than 1 per cent of their volume cull dne to butt rot on a board-ft basis, even for trees 30 inches in diameter. The corresponding figure for red oak was 3 per cent, for white oak 8 per cent. Roth and Sleeth (1939) reporting on butt cull (mostly of parent-stump origin) in unburned sprout oak stands reported 13 inches as the average extent of decay attributable to Armillaria mellea. The average height of a decay due to other wood-decay fungi frequently isolated was 42 inches. Hepting (1941) reported that Armillaria mellea butt decay at and above fire rounds in Appalachian oaks averaged 50 inches in height. Corresponding figures for other organisms frequently isolated ranged from 6.3 to 8.8 feet. Hepting, Roth and Sleeth (1949) in a study of discoloration and decay (organisms not specified) above increment borings found that in yellow-poplar the arerage extent of decay ten years after boring was ten inches for those wounds dereloping decay: 
It is fortunate that the versatile Armillaria mellea which seems important in the yellow-poplar decay-incidence picture is not an aggressive invader. At present, decay in living trees associated with soft rot fungi (Margarinomyces-type decay) is so little recognized and so inadequately evaluated that its economic importance can hardly be measured.

\section{The Stumps and Elite Stems 5 and 8 Years After Thinning}

The stumps and elite stems investigated resulted from thinnings made in 1953 in three plots situated in Coopers Rock Forest and previously described in Section II. In 1958, fifteen thinned sprout clumps were dug and dissected, and isolations were made from them five years after thinning. Another ten thinned clumps were similarly studied three years later. The elite stem and the stumps of adjacent ancillary stems were dug and dissected to determine which elite stems were stained or decayed and learn whether the source of infection was the stump of an ancillary stem.

In the case of the 15 elite stems investigated in 1958, it was found that the butts of nine showed no stain or decay (Figure 22). One showed what appeared to be only stain entering the butt of the crop tree through the adjacent stump of an ancillary stem removed in thinning five years before (Figure 23). Five showed both stain and decay entering through stumps of such ancillary stems (Figure 24).

The criterion used for distinguishing between stain and decay was the splinter test, using a knife blade to pry up splinters as described in Section III. Typical white or brown rot was not found in any of the 15 elite stems sampled in 1958. The wood classed as decayed showed a variable dark stain and was always situated near the pith and often strictly limited to a few annual rings. This should now be recognized as the Margarinomyces-type rot referred to in Section III, but in 1958 there was an inclination to doubt the reliability of the splinter test when used so close to the structurally weak tissues of the pith. The lack of basidiomycetes with clamp connections among the fungi isolated also led to a question as to whether any of the five trees seeming (on the basis of the splinter test) to have weakened wood should actually be classed as showing decay. The records showed that five of the six trees with discolored butts were decayed, but there was inclination to doubt it.

By 1961, eight years after thinning, when ten more elite trees were dug and examined, three showed a typical white rot (Figures 19 and 24) which yielded Armillaria mellea. In the presence of such easily demonstrable decay and a well-known decay fungus, the localized weakening of 


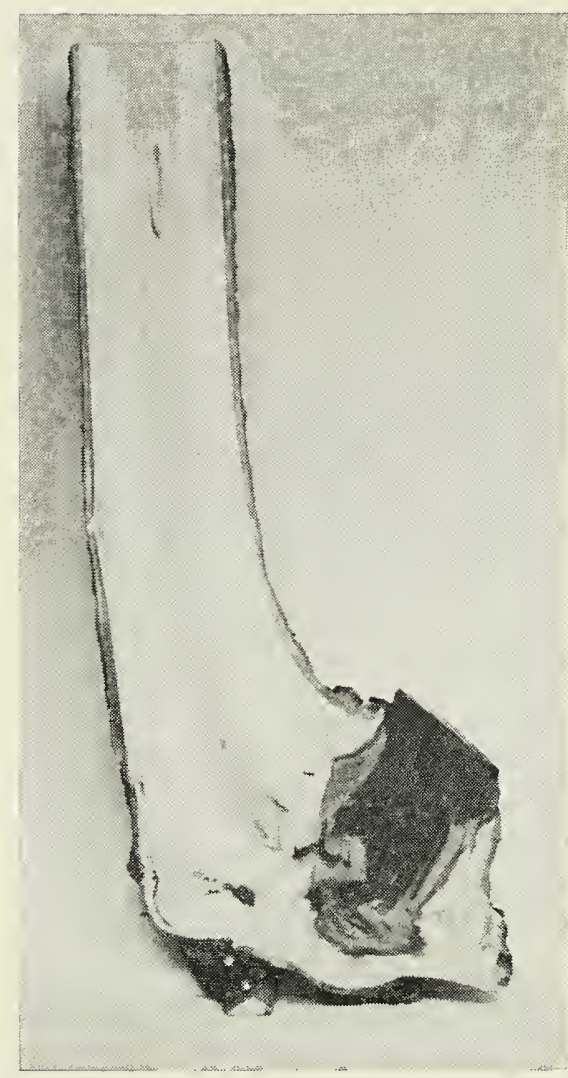

FIGURE 22. Sound butt of elite stem and adjacent stump of sprout removed in thinning five years previous to examination.

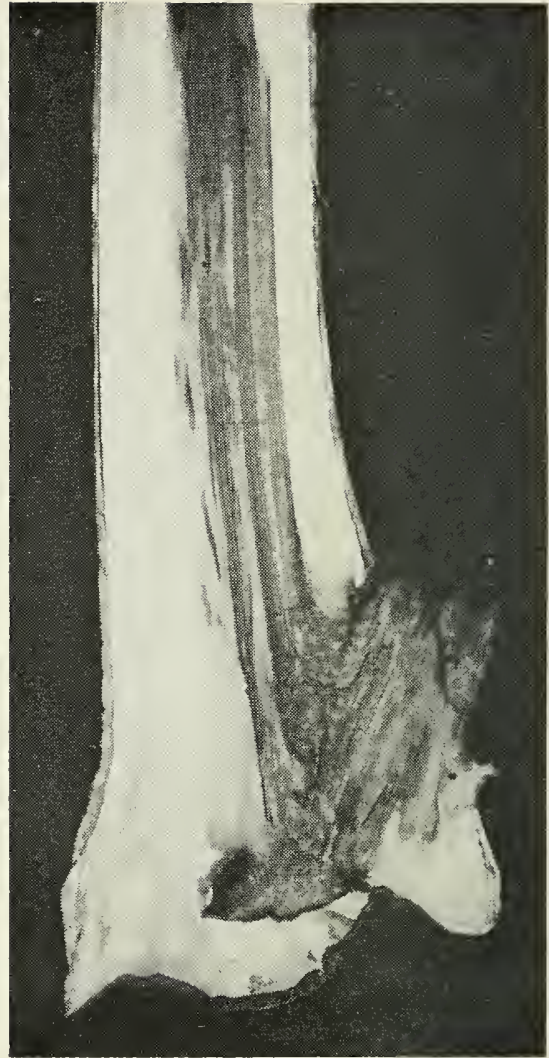

FIGURE 23. Discolored butt (blue butt) of elite stem; the discoloration entering through stump of adjacent sprout removed five years before in thinning.

darkened wood around the pith was disregarded, and in 1961 three trees were reported decayed by Armillaria mellea, and others were considered to exhibit only a dark stain. Most of the ten elite stems dug were listed as free of decay. In every case the stain and the decay found were traced to the cut stump of an adjacent ancillary sprout removed in the 1958 thinning.

In an abstract reporting the combined results of the 1958 and 1961 examinations, True (1962) recorded that three elite stems had decay with which Armillaria mellea was associated, seven had a dark basal stain, occasionally associated with brash wood, and the remainder appeared sound. 


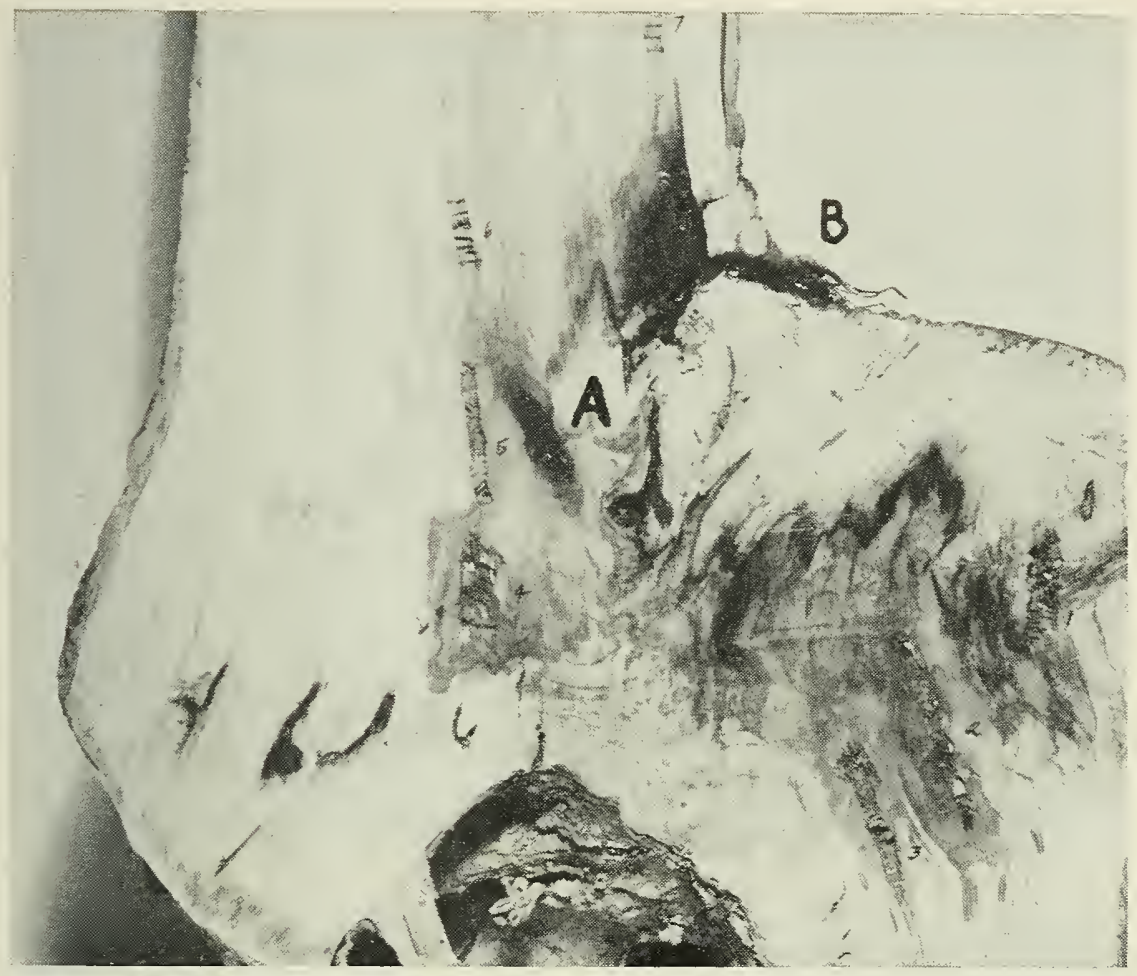

FIGURE 24. Discoloration (dark) and decay (white rot, at arrow A): entering butt of elite stem through stump of adjacent sprout removed in thinning five years before examination. Armillaria mellea was isolated from the white rot. Note the dark rhizomorphs at stump top next to the elite stem B.

The Fungi Isolated from Discolored and Decayed Butts of Elite Stems The known fungus isolated from portions of elite stems showing white rot was always and only Armillaria mellea. From the discolored and sometimes brash wood were isolated species of five genera: Fusarium, Phomopsis, Margarinomyces (Phialophora), Geotrichum and Pyrenochaeta (Figure 25). The five basidiomycetes previously reported in recently cut stumps (Peniophora sp., Pleurotus ostreatus, Polyporus adustus, Polyporus versicolor, Stereum purpureum) appeared not to have crossed over into or survived within, the butts of the elite stems or to have contributed to the defects found there. It was not ascertained that the Fusarium and Phomopsis species were the same as those isolated from one-years-old stumps but they appeared similar. The brash rood, recognized within portions of dark stained areas near the pith, seems almost certain to have been caused by representatives of one or more nonbasidiomycete genera: Margarinomyces, Fusarium, Phomopsis, or Pyrenochacta. Some 


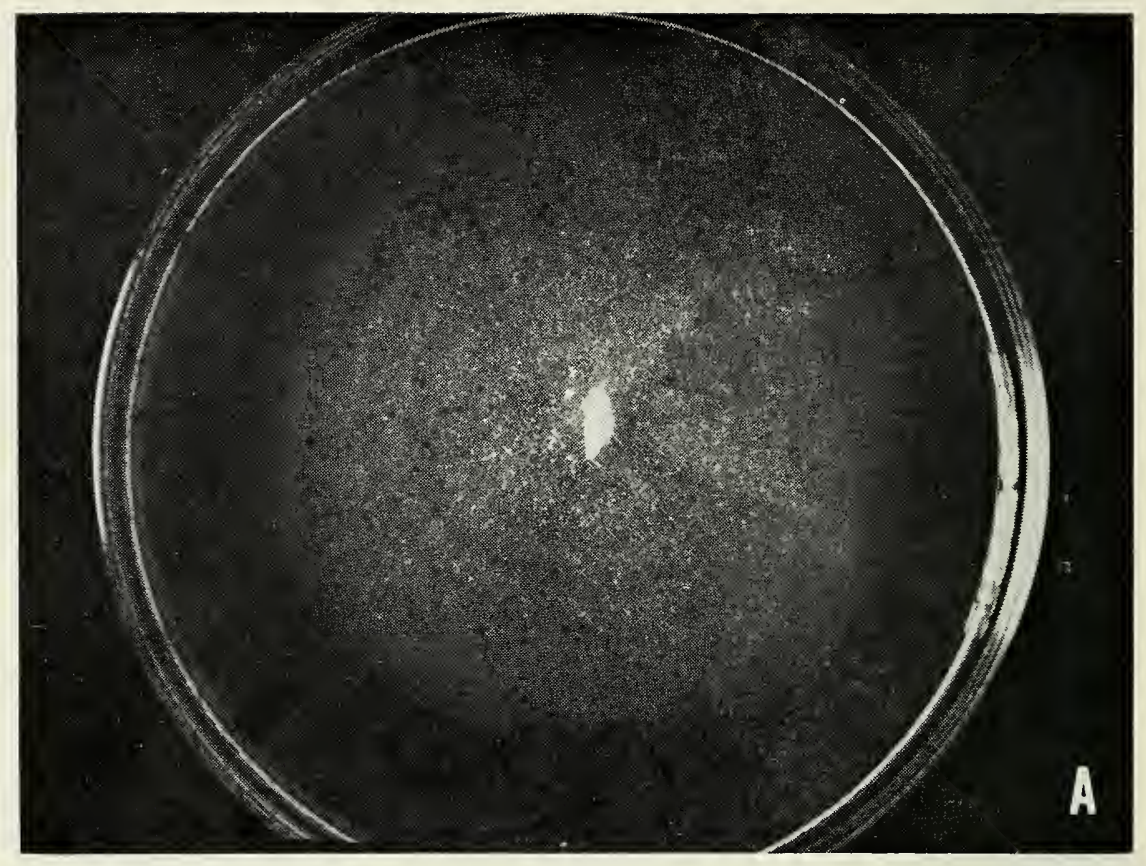

1.10.6.

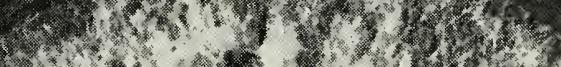

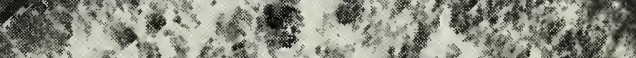

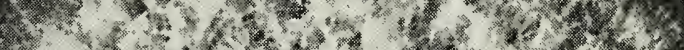

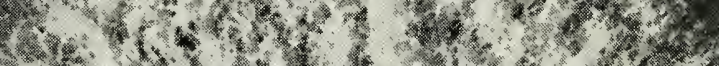

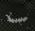

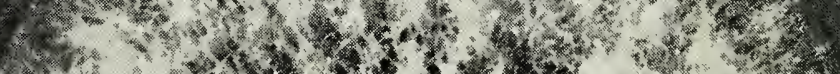

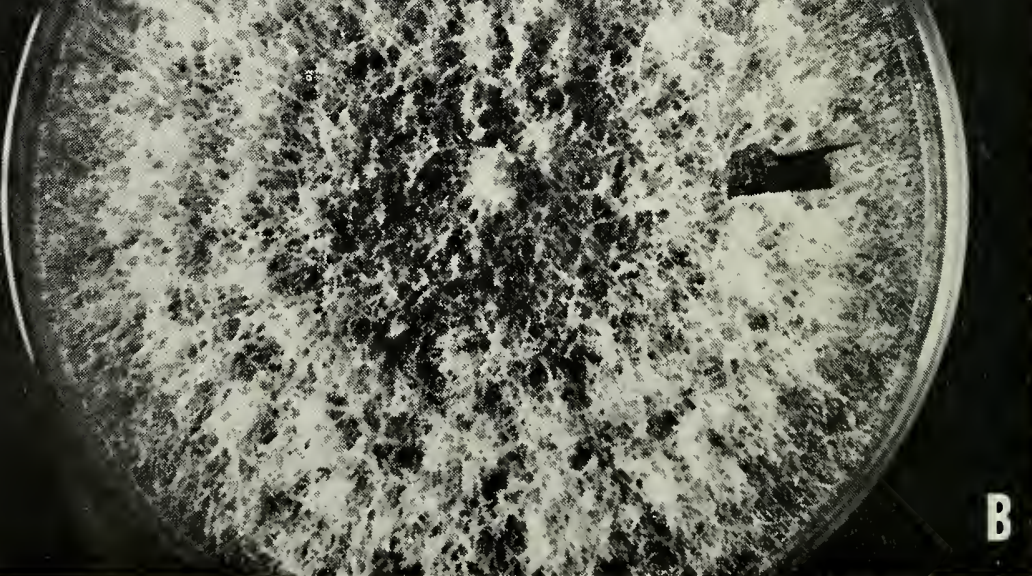



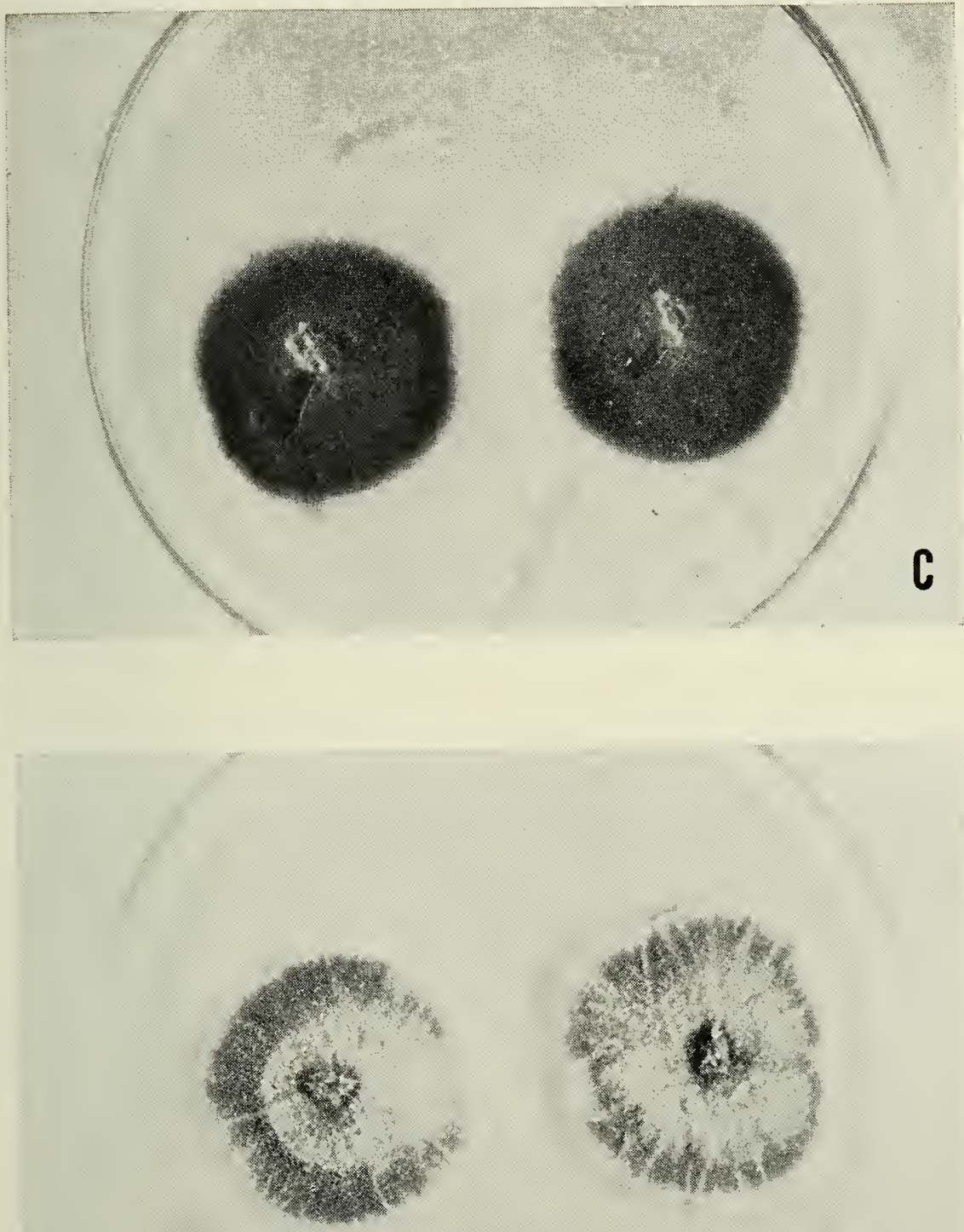

FIGURE 25. Fungi associated with discoloration and perhaps with pith-centered decay in the butts of elite stems five years after adjacent ancillary stems had been removed in a thinning. They presumably entered the elite stem through the cut stump of the ancillary stems. $25-\mathrm{A}$ is Fusarium sp.; $25-\mathrm{B}$ is Phomopsis sp.; $25-\mathrm{C}$ is Margarinomyces (Phialophora) sp.; 25-D is Pyrenochaeta sp. 
of these genera have been shown to include soft-rot fungi. These fungi have this identification because of their ability to cause a soft rot of the water-saturated wooden baffles of water-cooling towers in the British Isles (Savory, 1954). Soft-rot fungi, unlike those causing white or brown rot, grow within the cell walls of decaying wood and do not grow usually through the cell cavities of the tissues they invade (Duncan, 1960). They seem to be a functionally distinct group of nonbasidiomycetes. They have recently been reported in discolored or weakened tissues of living trees (Basham and Taylor, 1965; Etheridge and Laut, 1958; Good, Murray and Dale, 1955; Shigo, 1965) .

\section{THE SPECIAL SUITABILITY OF SEEDLING SPROUTS FOR STUDIES OF DECAY ENTRANCE THROUGH ANCILLARY STEMS OR THROUGH THEIR STUMPS}

The fact that seedling sprouts arise from very small stubs or stumps presumably lacking heartwood makes them especially suitable for studies of decay resulting from the removal of ancillary stems. The identification of the infection court is simplified here because all or nearly all decay found will originate from sprouts rather than parent stumps. This strengthens the credence that is given to the claim that in this study all stain or decay found in the bases of elite stems was traceable to the stumps of ancillary sprouts previously cut in thinning each sprout clump to a single, choice (elite) stem. The small size of the total number of sprout clumps dug and dissected (25) minimizes the validity of the 12 per cent figure obtained for those found affected by white rot alone and the larger but conservative figure of 32 per cent which would be appropriate when decay associated with soft-rot fungi is addecl. In view of the brief time between ancillary sprout removal and the cutting of the elite stems, the figures obtained for decay incidence may be presumed to be conservative.

Thinning stands of stump sprouts should also make the elite stems susceptible to decay entering through stumps of thinned stems as well as through the parent stump.

The question arose whether there would be less danger of butt rot developing within the elite stems if the less vigorous ancillary sprouts had been left to die of suppression. In Part B, that follows, the results of a study designed to help answer this question are reported. 


\section{Part B, Butt Rot in Stems Selected For Crop Trees (Elite Stems) Of Non-Thinned Sprout Clumps}

DEAD ANCILLARY STEMS OF NON-THINNED SEEDLING SPROUT
CLUMPS AS INFECTION COURTS FOR BUTT ROT OF ELITE STEMS

Studies reported in this part of Section IV were made in 1961 and 1962 (Ginns and True, 1967). The investigation involved 212 nonthinned multiple-sprout clumps of yellow-poplar seedling sprouts. Two plots were situated in Coopers Rock Forest and two on the Morgantown airport property. In Coopers Rock plots $\mathrm{A}$ and $\mathrm{B}$, and in plot $\mathrm{C}$ near the airport, sprouts were nearly 40 years old. Airport plot $\mathrm{D}$ contained mostly 20 -year-old trees. The site indices for plots A, B, C and D were 88, 66, 61 and 74, respectively. Each sprout clump dug and dissected consisted of two stems, one of which had died of suppression. Decay had invaded 26 per cent of all 212 elite stems, chiefly from the dead ancillary stem through its heartwood connection with the elite stem.

\section{The Stage of Ancillary-Stem Decay as an Indicator of} Butt Rot in the Elite Stem

The stage of ancillary-stem decay was found importantly related to the incidence of butt rot in the elite stem. Seven decay stages of the ancillary stem were distinguished and used in measuring this relationship. Decay stages 1-5 dealt with the condition of the standing dead stem, stages six and seven with the stub or cavity left by the fallen stem. Decaystage descriptions are based upon the condition of the ancillary stem or its stub within an area extending from 4 inches above to 4 inches below the height of pith union of the elite and ancillary stems:

1. Stem recently dead, wood appearing dry, no apparent decay .

2. Discoloration in both sapwood and heartwood of the dead stem, possibly some incipient decay.

3. Decay in sapwood only.

4. Decay in heartwood only.

5. Decay in both sapwood and heartwood.

6. Stem decayed, leaving traces of a stub and a partial cavity.

7. Stem completely decayed, only the cavity remaining.

The position of the clead stem (standing or fallen) and the condition of the stub or cavity left by its fall (Figure 26) indicated that at least two years passes after the death of the suppressed stem before decay from it invades the butt of the dominant stem. 

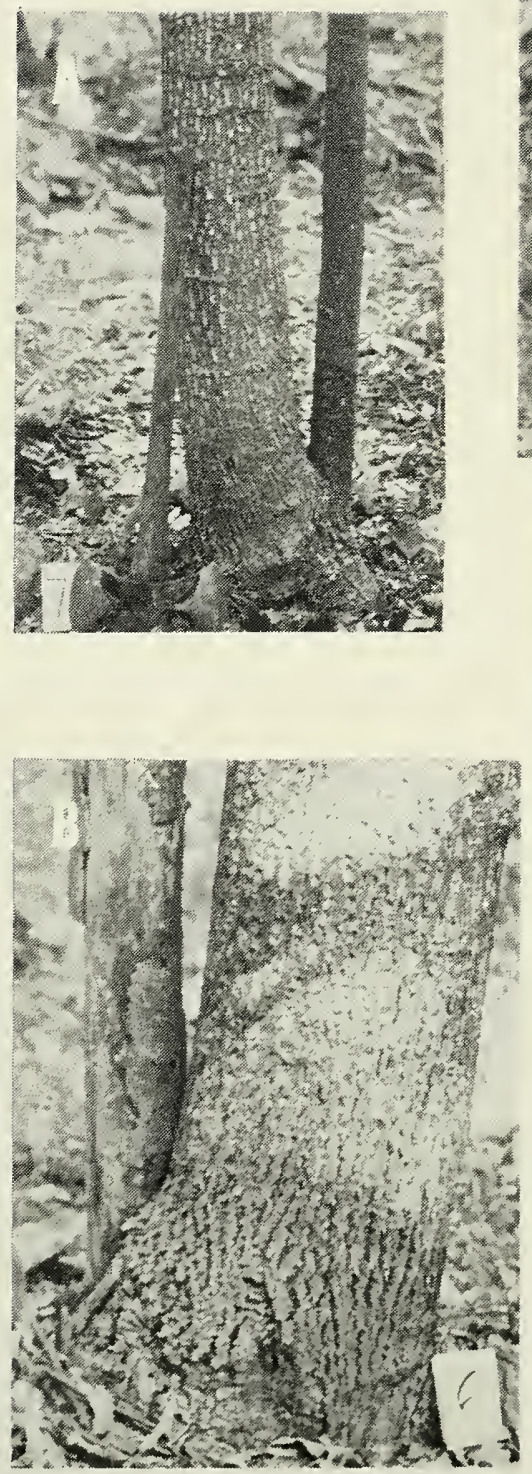
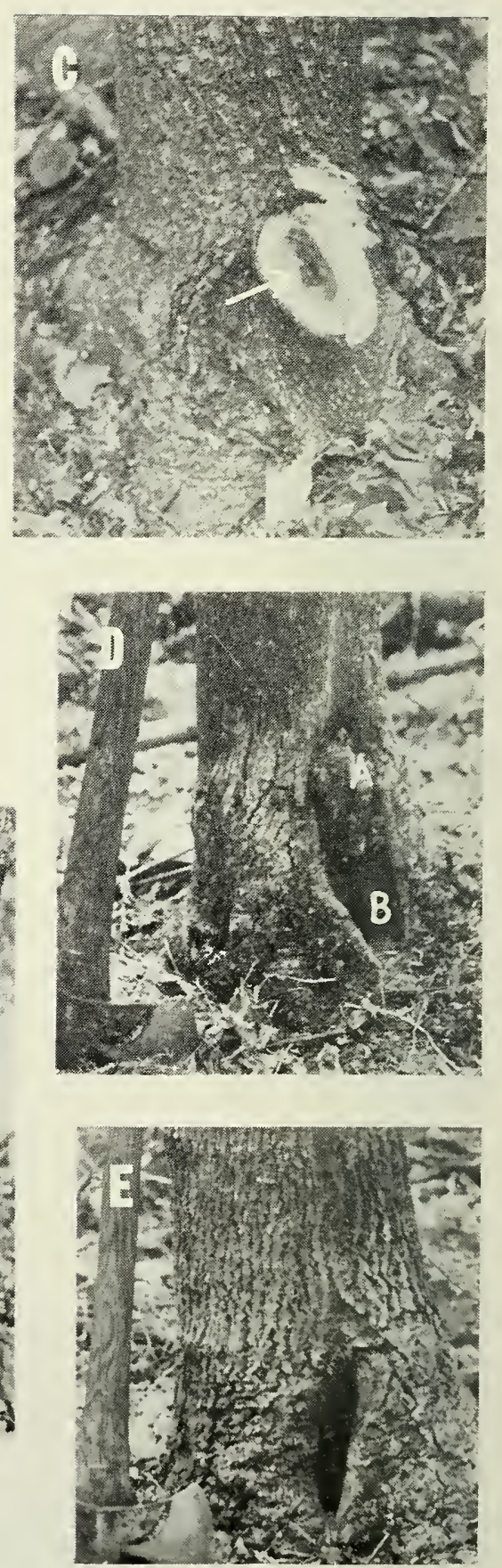
Incidence and Types of Heartwood Connection in Relation to the Incidence of Decay in the Elite Stem

Incidence and types of heartwood connection uniting elite and ancillary stems were influenced by the fact that only seedling sprouts were involved. V-type basal unions are found between sprouts which originate close together from a common parent stem or stump. Since seedling sprouts all arise from very small stumps, they characteristically have $V$-type rather than the U-type unions characteristic of more widely spaced sprouts from larger stumps. Mature stems with a $V$-type union have their separate heartwood columns united below the point of stem contact. It is at this point of heartwood union that heart-rot from the dead stem usually enters the live stem. Only 16 of the 226 unions dissected failed to show this heartwood connection. All these were 20-year-old sprouts of plot $\mathrm{D}$ and in none of the 16 had decay from the dead ancillary stem crossed over into the elite stem.

Where elite and ancillary stems were closely appressed for a considerable distance below their uppermost point of continous contact and above their point of pith union below (as is the case with long narrow $\mathrm{V}$-type unions), the bark layers of both stems were often partially enclosed within the crotch wood of the union (Figure 27). Such a layer of bark, called "included bark," sometimes partially separated the wood of the two stems. Paired pathological heartwood areas sometimes developed in the sapwood of both stems next to patches of included bark. Often these bark patches became engulfed in pathological heartwood (Figure 28 and 29). Such pathological heartwood areas often developed to unite the heartwood columns of the two stems with a pathological heartwood bridge (Figure 29). Across such pathological heartwood bridges decay fungi from the dead stem may pass into the heartwood of the elite stem a foot or two above the usual point of heartwood union. In 11 of 56 decayed elite stems, the decay originating in the dead ancillary stem had crossed over such a pathological heartwood bridge.

Occasionally the included bark and associated pathological heartwood serve as an infection court from which decay may spread into both sprouts (Figure 30).

FIGURE 26. Butts of two-stemmed yellow-poplar seedling-sprout clumps illustrating some stages of ancillary stem decay. 26-A shows a surface view of dead ancillary stem in Stage three (decay in sapwood) or Stage five (decay in sapwood and heartwood). 26-B shows a sectional view of ancillary stem showing Stage four (decay in heartwood only). 26-C chows stage six with traces of the decayed stem $A$ and a partial cavity $B$. 26-D shows Stage seven, the ancillary stem completely decayed with only the cavity remaining. 

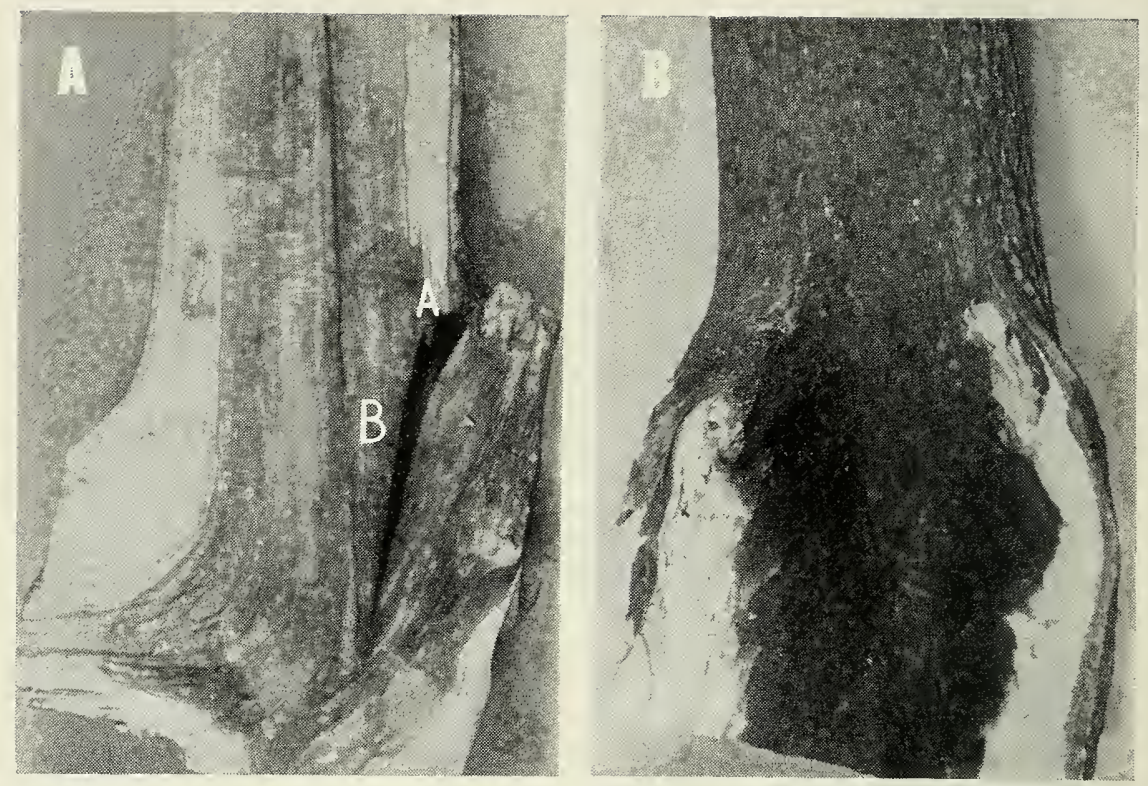

FIGURE 27. Included bark characteristically present in long narrow V-type unions often found in pairs of seedling sprout stems of yellow-poplar. 27-A shows radial section through the piths of elite and dead ancillary stems, showing: the dark included bark partially separating the woody cylinders of the two sprouts $A$, the pathological wood formed in sapwood region of the elite stem opposite the included bark $B$. 27-B show's section of another similar sprout union made at right angles to that shown in $27-\mathrm{A}$. Here it is clear that although the included bark extends to some distance down into the union it docs not completely separate the woody cylinders of the two sprouts which typically unite with each other along the margins of such a V-type union. It is clear that such unions are structurally weak.

Eight young trees in plot D having little or no heartwood showed (in cross section) pathological heartwood in the form of paired triangles with bases next to the included bark, the apex of each triangle being situated at the pith of each stem.

These narrow V-type unions correspond to the "weak" crotches discriminated against by arborists and orchardists.

Characteristics of the Elite Stem Influencing the Incidence of Butt Rot of Ancillary-Stem Origin Within It

Tree vigor index (Englerth, 1942) for each elite stem was calculated using site index curves for yellow-poplar (Renshaw and Doolittle, 1958) . Elite stems containing decay averaged 61 vigor-index points, five lower than the figure for non-invaded stems. Seventy-five per cent of the 56 invaded stems had vigor indices lower than 66 (Figure 31-B).

Crown class distribution of the elite stems examined was: dominant 35 , codominant 56 , intermediate 62 , and suppressed 59. The percentage 


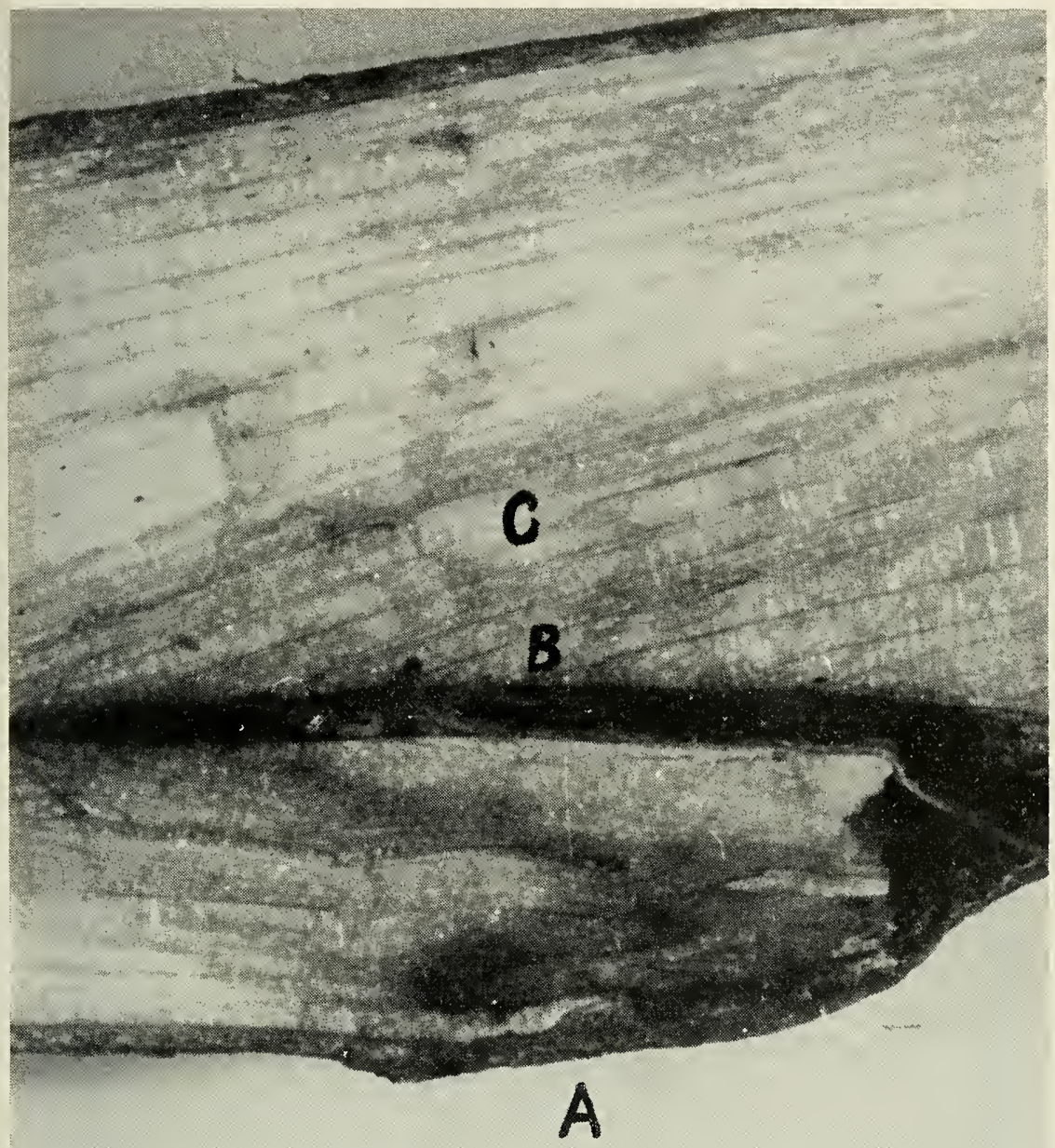

FIGURE 28. A section through a narrow V-type union of a small dead and decaying ancillary stem A (below) and a young living elite stem. Note the included bark B. Adjacent to the included bark and between it and the pith of the clite stem, pathological heartwood has formed within a young live stem still free of true heartwood C. Although this pathological heartwood may arise from the pressure placed on the cambuum here, it extends within the deeper tissues of the elite stem for some distance above the area of siem contact. Within the ancillary stem near to and below the decayed stub, decay-associated pathological heartwood involves all wood between the pith and the cambium for some distance below the decay. It gradually narrows toward the pith with increasing distance below the decay.

of elite stems decayed in each of these crown classes was 17, 29, 27 and 29 per cent, respectively, with wide plot-to-plot variation for values within each category. 


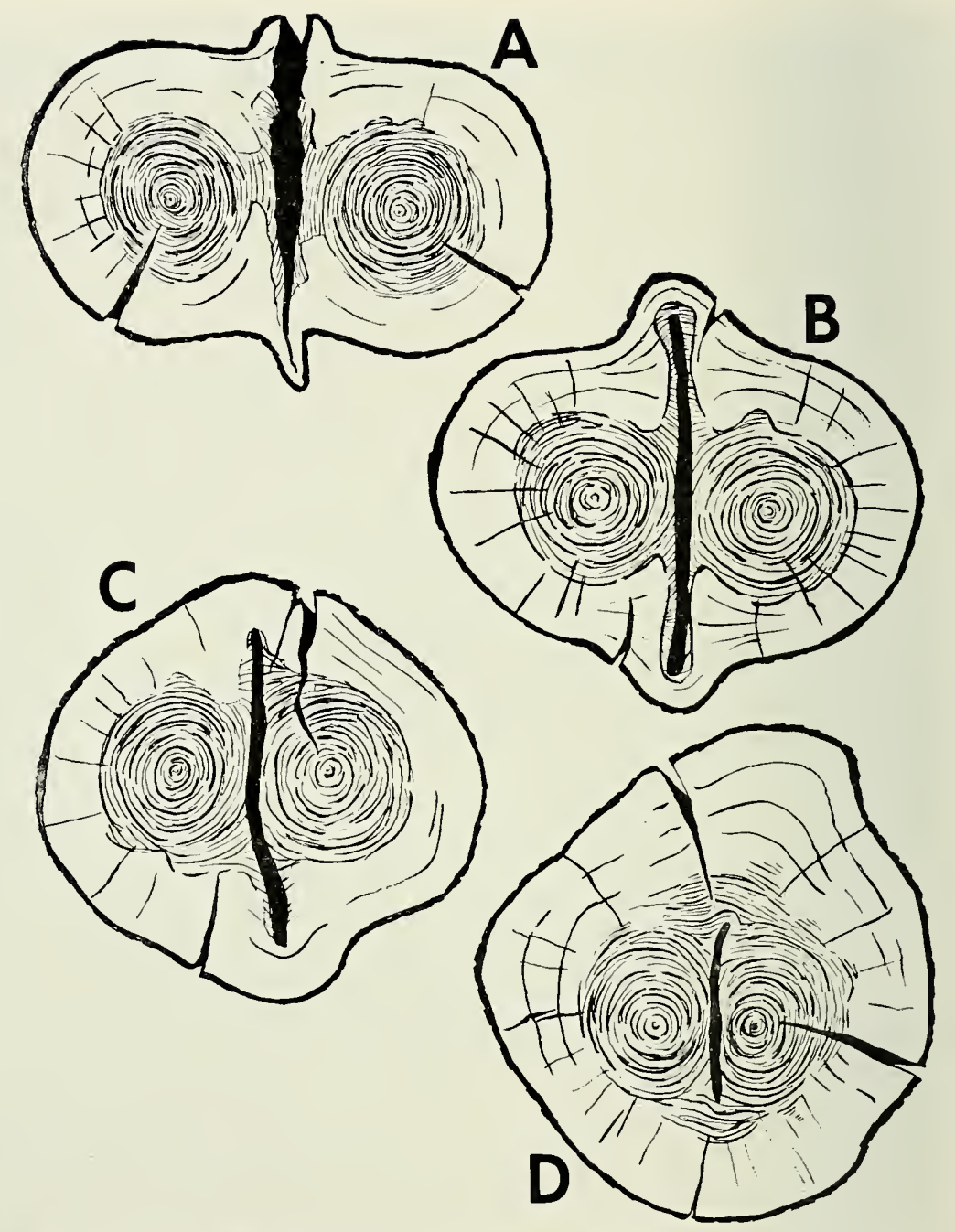

FIGURE 29. Four cross sections cut at succesively lower levels through a V-type union between two living yellow-poplar seedling sprouts. 29-A shows a section eut 22 inches above the ground line. Between the circumference of the heariweod circle in each stem, pathological heartwood extends irregularly to contact the included bark. 29-B shows a section eut 5 inehes lower and reveals that the area of pathological heartwood is greater and that it encircles the included bark. 29-C show's a cut 5 inches below 29-B (I foot abeve the soil line) and reveals the included bark considerably reduced, the pathological heartwood still continuous around it, the piths and heartwood cylinders of the two stems approaching each other. 29-D shows a section at 4 inches above ground and reveals pathological heartwood surrounding the included bark which may still separate the colmmns of normal heartwood. 


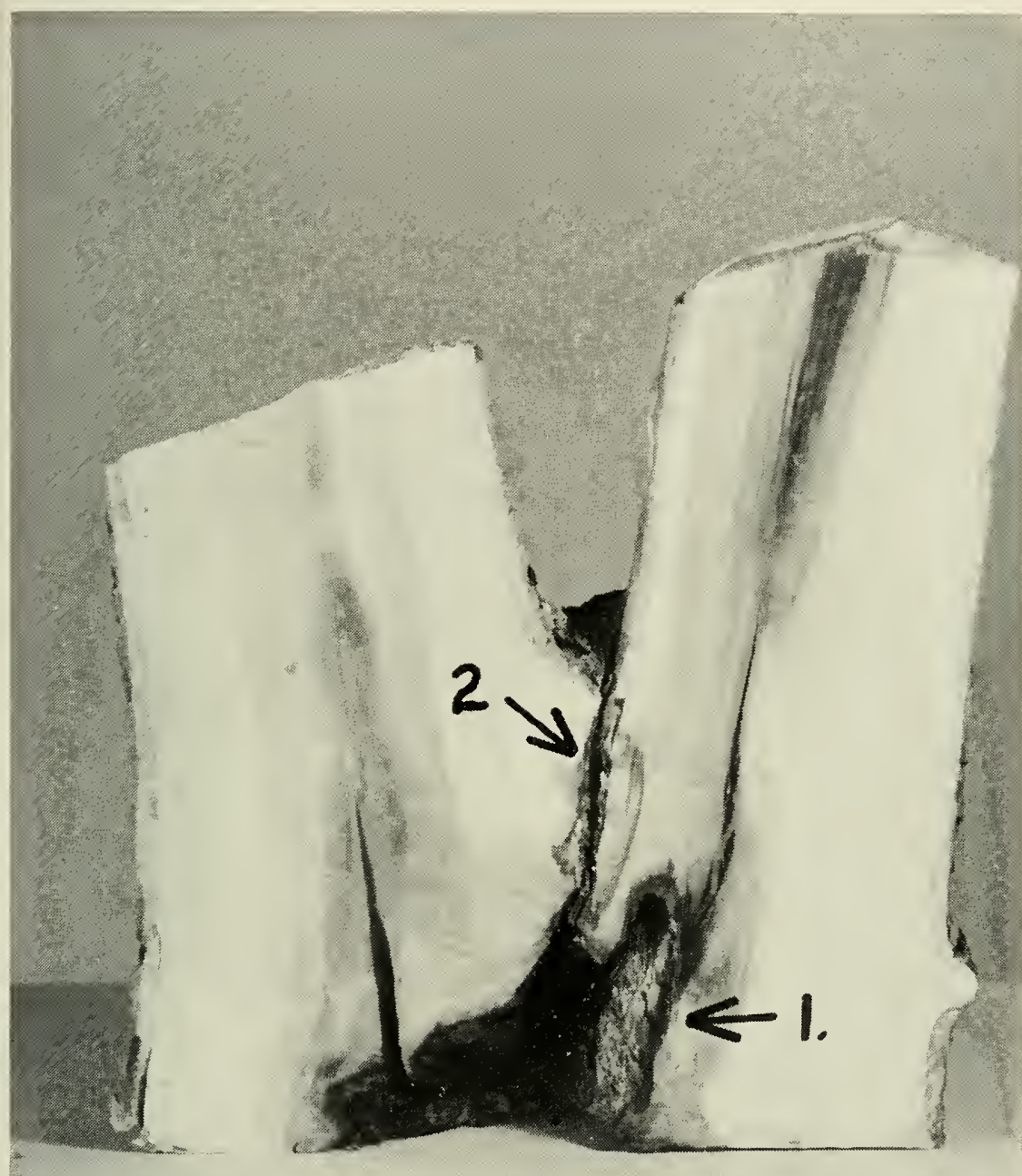

FIGURE 30. A radial section through the pith of two seedling sprouts revealing: (1) decay present in the lower part of the stem on the right, whosc origin is not here evident and, (2) decay spreading into both sprouts from the area of the included bark. The moisture held in the pocket of included bark and the pathological heartwood that develops here may make these narow $\mathbf{V}$-type crotches potential infection courts as well as bridges across which decay sometimes passes from a decaying ancillary stem into an adjacent elite stem. 
Elite-stem diameter of invaded stems (averaging 6.0 inches) was 0.7 inches less than the average of non-invaded stems when figures for plot D were omitted. Plot D included young trees, not all of which had yet established the heartwood connection. Only two of 18 stems 10.5 to 14 inches in diameter were invaded, whereas 28 of 93 between 1.5 and 5.5 inches were invaded. The difference in dbh between invaded and noninvaded stems was greatest on the best site (Plot $\mathrm{A}$ ), where invaded stems averaged 2.3 inches smaller than non-invaded stems.

Total heights of invaded and non-invaded stems in plot $\mathrm{A}$ were 58 and 68 feet, respectively. In plot B the figures were 48 and 58 feet, respectively. In plot $B$ the figures were 48 and 52 , in plot $C, 53$ and 55 feet. Generally, large thrifty stems of Plot A were not decayed, presumably because of their growth vigor. In Plot D the young stems (lacking a heartrood union or having only recently established one) were also lacking decay but in this case partly because of immaturity.

Radial growth rate of the elite stem was shown to be inversely related to decay incidence when elite stems having a single dead ancillary stem were classed in four growth-rate categories (Table 7 ). In plot A the average growth rate of non-invaded stems exceeded that of invaded stems by $0.6 \mathrm{~cm}$. In plot $\mathrm{B}$ the corresponding figure was $0.2 \mathrm{~cm}$.

Table 7. Radial Growth Rate During 1952-1961 of Elite Steais Having a Single Dead Ancillary Stem, Ix Relatiox to Percextage of Elite Steas IVith Butt Rot

\begin{tabular}{cccc}
\hline \hline $\begin{array}{c}\text { Average Annual Growth } \\
\text { During 1952-1961 } \\
\text { (One-cm Classes) }\end{array}$ & $\begin{array}{c}\text { Total } \\
\text { Stems } \\
\text { (No.) }\end{array}$ & $\begin{array}{c}\text { Invaded } \\
\text { Stems } \\
\text { (No.) }\end{array}$ & $\begin{array}{c}\text { Total } \\
\text { Stems Invaded } \\
(\%)\end{array}$ \\
\hline 1 & 25 & 7 & 28 \\
2 & 24 & 8 & 33 \\
3 & 15 & 2 & 13 \\
4 & 15 & 2 & 13 \\
\hline
\end{tabular}

The vigor index of the individual elite tree, its crown class, its diameter, total height, and radial growth rate were all inversely correlated with the rate of incidence of butt rot in the elite stems. This indicates that more vigorous stems were less susceptible to decay.

\section{The Fungi Chiefly Responsible for Discoloration and Decay}

The fungi chiefly responsible for discoloration and decay in elite stems included Armillaria mellea, two species of Margarinomyces and unidentified basidiomycetes. Species of Fusarium, Trichoderma and Scopulariopsis were isolated from the ancillary stem and sometimes from heartwood and pathological heartwood of the elite stem. 
Summary of Relationship of Decay in Elite Seedling Sprout Stems as Associated with Dead Ancillary Stems of the Same Clump

The clearly shown relationships may be summed up by stating that time is required (usually two years or more) for decay to enter the dead ancillary stem and spread from it into the elite stem. Decay had seldom (4 of 56 cases) entered the elite stem of clumps in which the dead ancillary stem was still standing. But the 24 elite trees having dead ancillary sprouts in the last stage of decay (completely decayed, with only the cavity remaining at the base of the elite stem), nearly 70 per cent showed butt rot.

The heartwood union required for the spread of decay from the dead to the living stem was nearly always present, partly because seedling sprouts characteristically have $V$-type basal unions. Where V-type unions were narrow, pathological heartwood associated with and surrounding patches of included bark formed an additional heartwood connection through which decay fungi might pass from the dead stem into the elite stem. Such areas of included bark and associated pathological heartwood sometimes served as infection courts.

Every evidence of vigor in the individual elite tree: vigor index crown dominance, cliameter, height and radial growth rate, was inversely related to the incidence of butt rot in elite stems paired with dead stems in a single sprout clump.

This study, like the others included in this bulletin, is chiefly a study of butt decay incidence in comparatively young trees. Little is revealed concerning the extent of the decay.

\section{FACTORS FOUND AFFECTING BUTT ROT INCIDENCE IN SPROUT YELLOW-POPLAR AS COMPARED WITH SOME PREVIOUSLY RE- PORTED FOR OTHER SPECIES}

Recommendations for thinning hardwoods have been based largely on specific information obtained from studies of sprout oak stands (Roth and Hepting, 1943a, 1943b and Roth and Sleeth, 1939) and from observations reported for Northern hardwoods (Campbell, 1938). The applicability of these recommendations to the thinning of yellow-poplar has been questioned (True, 1953).

In several ways the butt rot situation in sprout yellow-poplar is similar to that of sprout oak. Yellow-poplar heartwood, like oak heartwood, originates within sprouts at nodes 1 to 3 feet above the point of sprout origin. The development of a heartwood connection is an important prerequisite for sprout infection from the decaying parent stump in oak and in Northern hardwoods, and the same is usually true for yellor- 
poplar. Roth and Sleeth (1939) found 86 per cent of oak sprout butt rot traceable to the parent stump. The corresponding value for yellow-poplar was 84 per cent (Byler and True, 1966). In yellow-poplar, as in oak, highorigin sprouts are more likely to develop butt rot at an early age, as are the sprouts of both species that arise from larger stumps. It is clear that the butt rot problem in hardwood stump sprouts has many similarities even where different tree species are attacked by different butt rot fungi. Maple sprouts attacked by the trunk rot fungus Polyporus glomeratus presented a different pattern of decay (Shigo, 1965c). In studies on the infection of the elite stem from a dead suppressed ancillary stem, decay of ancillary stem origin was seldom found within the elite stem until after the dead stem had fallen over (Ginns and True, 1967). This was in substantial agreement with observations made by Roth and Sleeth (1939).

The yellow-poplar studies show some situations differing from those reported for oak. The Margarinomyces-type rot was not reported in oak, atthough species belonging to genera which include soft-rot fungi have been reported from living Northern hardwoods (Basham and Taylor, 1965; Shigo 1965b). The fungus most often associated with the white rot of living stems of yellow-poplar is Armillaria mellea, a common invader of roots and butts of Northern hardwood sprouts rather than Stereum gausapatum which caused most sprout butt rot in oak. Although in oak the heartwood prerequisite for the spread of decay from stump to sprout seems limited in its development, there is developed in yellow-poplar a pathological heartwood discoloration through which decay of heartwood origin may spread into and through sapwood. This makes the decay observed in yellow-poplar more versatile than it appears to be in oak. The situation suggests the one reported by Shigo (1965a) for Fomes igniarius decay in maple. The developmental story of pathological heartwood in yellow-poplar and its consequences remain to be elucidated. Yellow-poplar heart rot of stump origin sometimes spreads downward through the stump into the roots. In doing so it may be able to enter sprouts of low origin on the stump, or even root sprouts. It has been shown to spread radially outward toward the cambium with its precurser, the pathological heartwood; the latter even penetrating the bases of young sprouts still lacking ordinary heartwood. The observed persistence of parent stumps of yellow-poplar sprout clumps below the leaf litter and the observed development of pathological heartwood within them suggest that these old stump bases may join together with a common pathological heartwood union eren widely separated yellow-poplar sprouts. Sprouts showing such $\mathrm{U}$-type unions may be functionally united much like V-type unions so far as decay development is concerned. If this is true, the 
removal of one of two yellow-poplar sprouts having such a U-type union may subject the other sprout to eventual butt decay.

Where suppressed ancillary stems of seedling sprouts of yellow-poplar are concerned, all unions are $\mathrm{V}$-type because of the small size of the parent stump. Here the development of a pathological heartwood bridge in association with patches of included bark may permit the elite stem to be infected sooner. This happens if the decay present in the dead stem passes across the pathological heartwood bridge rather than spreading downward within the dead stem to the point of its normal heartwood union with the elite stem, a foot or two below. Areas of included bark with which pathological heartwood is associated may also serve as infection courts for living stems. The fact that a pathological heartwood connection may serve as well for decay spread in yellow-poplar as cloes true heartwood is a feature of this species unreported for oak.

In yellow-poplar there is evidence that both incidence and rate of spread of decay are inversely related to tree vigor.

\section{Microorganisms Associated With Butt Decay In Sprout Yellow-Poplar}

An extended series of attempted isolations of microorganisms from the wood of yellow-poplar sprouts with butt decay have yielded bacteria, alone, or with fungi in $1 / 3$ to $2 / 3$ of the isolations attempted. The interaction of these bacteria so often found within yellow-poplar tissues, with the cells of yellow-poplar and with fungi found within the tree, constitutes a frequent but inconstant relationship whose nature and importance are mostly unassessed in these studies. The bacteria found were not associated with "wet wood" (Hartley, Davidson and Crandall, 1961) nor with notable changes in the $\mathrm{pH}$ of the yellow-poplar wood. It is obvious that if we consider the filamentous fungi alone we shall have only a part of the story. And yet this is what we propose to do in this section, neglecting (but aware of) the possible influence of bacteria on the wood and their influence on the nutrition of the various fungi also found within yellow-poplar sprouts.

\section{INFECTION COURTS FOR FILAMENTOUS FUNGI}

It is clear that the entry of fungi, and presumably of bacteria also, into yellow-poplar sprouts is easy at the cut surface of the parent stump. Whether it is large or small, the wound at the stump top may serve as an infection court. If the stump is old enough or large enough to have heartwood exposed at the cut, important wood-decay fungi are likely to 
be included among the microorganisms entering. These and other organisms entering through the stump top are able to sustain themselves and to spread within or among living or dead tissues. Stumps created by the removal of one or more sprouts from a sprout clump promote the entry of organisms into the vascular system of the resiclual stems.

Dead stems found among living sprouts of a single clump admit to the vascular system of the living stems those organisms which are capable of entering first into the tissues of the dead sprout and passing from them into either the sapwood or the heartwood of live stems. Standing dead stubs usually fall or break off near the groundline because the tissues near the groundline are more moist and decay is more rapid here than above. When this occurs it is possible that an even wider range of microorganisms can penetrate the open end of the broken stub. Small wonder, then, that many microorganisms are found within living sprouts.

\section{SURVIVAL AND SPREAD OF MICROORGANISMS WITHIN LIVING TREES}

Microorganisms must both survive and spread within living trees if they are to set up a significant relationship with the host or to react to each others' presence there. Armillaria mellea seems in this study to have behaved as a weak parasite invading chiefly at wounds where heartwood (a nonliving food base) was exposed. Occasionally Armillaria mellea invaded the surface sapwood of roots near the base of the stump.

Species of Fusarium and Phomopsis penetrated deep within oneyear-old stumps, and five and eight years later species of these genera were found in but tissues of adjacent live stems. It is not known that these fungi nor the species of Margarinomyces, Pyrenochaeta or others found in living stems are disease-inducing parasites, although species of some of the genera are recognized as such. It seems more likely that such organisms are soft-rot fungi and that one or more of them cause the brashness of the heartwood adjacent to the pith. This leaves a large area of uncertainty concerning the role played by these fungi as well as by the bacteria found in living yellow-poplar sprouts.

\section{POSSIBLE NUTRITIONAL INTERRELATIONSHIPS WITHIN THE STUMP AND LIVING SPROUTS}

In view of the uncertainties which predominate in this situation it may be helpful to consider some possible interrelationships in the hope that in time such speculation may be replaced by more certain knowledge. 
Microorganisms in or among the living or dead parenchyma cells and the vessels of a living tree such as yellow-poplar are in a position to absorb some of the nutrients present there. In doing so they may compete with the growing tissues of the living host which also require these nutrients. The microorganisms may gain or lose in this competition, depending at least in part on the innate vigor of the host tissues involved. Such a relationship existing within freshly cut sprouting stumps may partly explain the survival of those parts of the stump nearest to a vigorously growing sprout and the disappearance of stump and root tissues functionally farthest removed from such sprouts.

Perhaps substances given off by xylem-inhabiting microorganisms injure host tissues locally or at a distance if they become concentrated. The degree of such injury may be variable and almost imperceptible. This injury may be expressed merely as a growth reduction, the cause of which could be properly assigned only with difficulty.

Organisms capable of using host cell-wall substances as food are able to obtain energy from such sources. Soft-rot organisms are capable of gaining at least part of their nutrients from host cell walls, as do the white rot and brown rot fungi.

\section{SEQUENCE AND INTERACTION AMONG INVADING MICROORGANISMS}

Microorganisms may frequently invade living trees and such products as logs and lumber in a sequence which appears so characteristic as to suggest that it is not random. This leads to speculation on the reasons for some of the specific sequences observed. The nonchromogenic molds and the chromogenic wood-stain fungi often appear to precede most wooddecay fungi in attacking wood products (Shigo, 1962).

One explanation for this might be that nonbasidiomycetes are more promptly introduced than are decay fungi to suitable substrates by insects especially equipped to do this work (Leach, 1940). The spores of nonbasidiomycetes may also be wind-borne (Verrall, 1941), as are the spores of basidiomycete-decay fungi. The latter are so abundantly present in the air as to cause doubt of the validity of the assumption that spores carried by insects would get to the substrate sooner.

Another suggestion might be that even if infection by molds and by wood-stain and wood-decay fungi occurred simultaneously, the faster rate of growth characteristic of some nonbasidiomycetes rould give them an initial advantage. Further study is needed regarding the nutritional and environmental requirements of fungi growing through wood. 
Wood is poorly supplied with some food substances required by wooddecaying basidiomycetes. Some kinds of nitrogen are in short supply in the xylem of living trees (Bollard, 1958) and in rood products (Laidlaw and Smith, 1965).

The presence of nonbasidiomycetes may bring about nutritional enrichment of the rood. Possibly their mycelium may, while alive, give off nutritionally useful substances. Perhaps, when the mycelium dies, substances needed by basidiomycetes are liberated. Merrill and Cowling (1966,a), however, suggest that such substances may be withdrawn from dying cells for reuse by the living portion of the mycelium. Another way in which they may be made available to the invading wood-decay fungi may be by direct mycoparasitism of wood-decay fungi upon pioneering nonbasidiomycetes. Recent findings by Griffith and Barnett (1967) regarding the parasitism of basidiomycetes on wood-stain fungi and others in laboratory culture make this appear to be a possibility.

Studies by the authors have suggested that fungi do succeed each other in trees and wood but these studies have done little to demonstrate or explain it. A few points may be made, however. (1) The first fungi to attack the top of a freshly cut stump include rood stainers. The black stain near the tops of one-year-old stumps frequently showed wood discoloration typical of the effect of these fungi on wood. Yet, one year after the stumps were cut, Ceratocystis species were not found there. (2) Among fungi confined to the stump top were species of Trichoderma, Aspergillus and Penicillium whose characteristically abundant sporulation and rapid growth gave them every opportunity of penetrating deep within the stump. But such was not the case. Basidiomycetes were isolated at all levels in the stump but shared the deeper tissues with species of Fusarium and Phomopsis. Species of rood-decay fungi were isolated in combination with each other and with species of Fusarium and Phomopsis.

Within the butts of living elite stems associated with cut stumps and with dead ancillary stems, species of Margarinomyces (Phialophora), Pyrenochaeta and Glocosporium were associated with discolored and often brash tissues along with species of Fusarium and Phomopsis. Such nonbasidiomycetes were isolated from brash and discolored tissues of sprouts growing from stumps cut 14 years earlier. The localization of brash rood of the Margarinomyces-type rot close to the pith suggests that the causal organisms may have found needed nitrogen in and near the parenchyma tissue of the pith, since Merrill and Cowling $(1966, \mathrm{~b})$ found this area comparatively rich in nitrogen. In the case of sprouts from 18and 22-year-old stumps, some white rot was also found. Discolored brash 
wood seems not very likely to be followed by white rot. The same conditions seemed to favor the pith-centered brashness and the white rot.

\section{Application to Forestry Practice}

Yellow-poplar should be regenerated in even-aged stands or groups because it is intolerant of shade, especially after the initial growth stage has been passed. It can be readily regenerated by clearcutting areas of several acres or by cutting openings as small as one-half acre. In both situations stems may originate from stumps and from seed.

Butt rot is thought to be an important factor in mature yellow-poplar stands which are entirely or mainly of sprout origin, especially where the site quality is low. However, it seems to be of little importance to smalldiameter stems of sprout origin since the decay has so little time to develop.

Yellow-poplar sprouts readily and may sprout from stumps of all sizes. Sprouting of stumps of different sizes was investigated by True (1953), and over 90 per cent of the 6-inch stumps produced sprouts. Although sprouting ability decreased with size, stumps 30 inches in diameter produced sprouts more than 30 per cent of the time. Consequently, wherever harvest cuttings which create openings in stands are made, sprouting may be expecterl, and the proportion of sprouts to seedlings should increase in the newly developing stand because of the greater initial growth rate of the sprouts, which should result in their overtopping many slower-growing seedlings. Even small yearling yellowpoplar seedling stems which have been cut or killed back from the tip will produce sprouts.

The occurrence of seedling spouts from stumps 2 inches or less in diameter is common in young yellow-poplar stands where small seedling stems have been damaged by animals, fire, or frost. Thus even stands of yellow-poplar originating from seed may be composed largely of seedling sprouts.

\section{GENERAL IMPORTANCE OF DECAY IN SPROUT YELLOW-POPLAR STANDS}

There is general recognition that single-stemmed yellow-poplars of seedling origin growing on good sites are likely to be free of decay unless they are wounded by fire, logging, frost, or violent weather. The present study suggests the same is true for single-stemmed seedling sprouts.

Where multiple-stemmed seedlings and multiple-stemmed seedling sprouts are concerned, there are two additional ways in which decay may be expected to enter the crop trees: 
1. Though the suppression-caused death of the smaller stems of the clump. Such dead stems, killed after they develop heartwood, often serve as infection courts through which fungi which cause decay enter the stem of the living crop tree.

2. Through the stumps or stubs created by the removal of such stems after they are large enough to have heartwood that links the cut stump with the crop tree.

Single-stemmed trees of stump sprout origin do not develop the infection courts characteristic for multiple-stemmed trees but do have a parent stump large enough to contain heartwood, a single infection court of major importance. The parent stump, with heartwood exposed at the cut surface, is invaded by decay fungi which often spread into the sprout. Decay does not enter the sprout until after the heartwood of the sprout develops and extends downward to unite with the decaying heartwood of the parent stump.

Multiple-stem sprouts of large yellow-poplar stumps have the infection courts and avenues of decay spread characteristic of all multiplestem trees as well as those of stump sprouts. These trees then have the greatest chance of having butt rot, and perhaps only a few of them may be expected to have sound butts by the time they reach a size required for large-diameter products. Work in this study has chiefly been with younger stands, so it gives inadequate information on the extent of decay to be expected in later years. On the basis of general information the authors believe that the extent of the damage due to but rot can be expected to be low in old stands growing on the best sites but higher on poor-quality sites.

\section{TYPES OF DECAY AND ECONOMIC IMPORTANCE}

Two types of decay were observed in sprout-origin yellow-poplar. A brashness of the wood centered on and immediately surrounding the pith (Margarinomyces-type rot) seems likely to have little effect on the strength of tissues far removed from the pith. Products cut from the sapwood and outer heartwood of affected logs would presumably be unaffected even though they sometimes are similarly discolored. Boards cut through or near the pith or those portions of other products containing the brash tissues of discolored inner heartwood may be to weak for some commercial uses. The second type of decay, white rot, is much more obvious and much more destructive to the wood.

Worthwhile further investigations could be made concerning the importance of the pith-centered brashness which is the first type of decay 
to develop in young stems and is the more extensive of the two decays observed. However, it seems likely to be of less economic importance than the white rot. Although both types of decay appear to develop indepenclently, they seem to enter at the same infection courts and to be favored by the same predisposing factors.

\section{VIGOR !NDEX AND SITE QUALITY}

Both decay incidence (Ginns and True, 1967) and rate of decay spread (Byler and True, 1966) are related to the vigor of yellow-poplar stems as evidenced by crown class and position in the stand. In general the less vigorous the stem, the more common is butt decay and the faster is its rate of spread after entering the bole. Thus, suppresssed and overtopped yellow-poplar sprout stems and those expected to become so should be discriminated against in situations where they may be removed and the more vigorous stems left.

Site quality might be expected to have a similar effect on the incidence of decay, but this could not be detected in this study. Differences in site quality are related to the incidence and persistence of Nectria and Fusarium cankers on the boles of yellow-poplar (Nelson, 1940; Dochinger and Seliskar, 1962) and presumably to the time required to heal basal-stem frost cankers. Stem cankers seem most serious in stands growing where the site quality is poor and the general vigor of the stems is low. Cankers themselves constitute a defect and may in time become infection courts for decay organisms.

Thus yellow-poplar should be kept to the higher-quality sites and, in cutting a portion of the stems in any one sprout clump, the less vigorous stem or stems should be removed to keep butt rot at a minimum.

\section{INTERMEDIATE CUTTINGS}

Cleanings or weedings may be needed when stump sprouts and seedling sprouts have reached a dbh of 2 inches to allow potential crop trees a chance to develop without being heavily suppressed by individuals crowding from the sides or overtopping these trees.

Yellow-poplar stumps 6 inches or more in diameter are certain to have heartwood, and it may be expected that the heartwood which will form within the young sprout stems will usually connect with that of the stump. Even low-origin sprouts may eventually become decayed because, in yellow-poplar, the formation of pathological heartwood may provicle a passageway for the decay fungi.

When stocking of the young stand is aclequate or high, the entire stump-sprout clump should be cut unless all its sprouts are overtopped and expected to die soon. 
Where the stocking of the stand is inadequate, sprouts may have to be left, and a decision must be made concerning how many and which ones to leave. A recommendation would be that one stem, or at most two originating near the groundline, be left per stump. If two stems are left they should originate some distance apart and, where possible, be tall and vigorous. Since decay spreads more slowly in the wood of vigorous sprouts, a longer time will be required for decay to develop extensively in such sprouts, particularly if they are of low origin. Often sprouts of high origin are dominant but they should not be chosen as crop stems. Cutting low stumps is one means of improving the quality of sprouts produced because only low-origin sprouts can develop.

Small stumps (2 inches in diameter or less) seldom have heartwood. Consequently decay does not affect or spread from the stump to sprouts that grow from them. Decay, therefore, need not receive silvicultural consideration unless multiple stems develop. Some of these multiple stems may die of suppression or may be removed in thinning. In either case they may serve as infection courts.

Here also, where stocking is adequate, the entire sprout clump may be removed. If stocking is low it is recommencled that a single most desirable sprout be left and the others be cut before heartwood is formed. Decay would not be expected to be a factor in a seedling sprout so treated.

Sprouts from stumps between 2 and 6 inches in diameter may be treated like those from smaller stumps if heartwood is lacking or like sprouts from large stumps if heartwood is present. Observations on any area should help indicate the size of stumps having heartwood.

Thinning made in yellow-poplar stands of sprout origin should take into consideration the probable presence of decay as well as the effect of the cutting (thinning) on the development of decay in the stand.

The size of the stump from which the sprouts grew should be known in some instances before the best method of treatment for the sprout clumps can be decided upon. A knowledge of previous stand treatment may supply all the needed information. Where this is not available cutting and splitting a few sprout clumps close to the groundline may give the information needed on parent stump size.

Sprouts from the larger stumps containing heartwood may all become infected with butt rot from the parent stump. As sprouts grow from large stumps they often form a V-type union if they originate close together on the stump. If they originate farther apart they may at first show the U-type union. All sprouts developing from small stumps have $V$-type unions. It seems likely that in yellow-poplar most sprouts appearing to have U-type union (with no heartwood connection between them) 
may be presumed to develop into V-type unions as stems grow in diameter, and pathological heartwood may be expected to unite their individual heartwood columns.

Thinnings may sometimes be carried out in yellow-poplar sprout stands 30 years old or older. Where such thinnings involve sprouts from stumps 6 inches or more in diameter, high-origin sprouts should have, or soon develop, butt decay resulting from a heartwood connection. Loworigin sprouts may become decayed with the infecting fungi travelling through regions of pathological heartwood ahead of the decay itself. When thinning it would be preferable to cut all sprouts of the clump if this could be done without reducing the stocking too seriously. If the clump must be left, reduce the number to one or perhaps two vigorous sprouts of low origin. Sprout stems of low origin may escape decay or damaging decay will be later to develop than for high-origin sprouts.

Small stumps less than 2 inches in diameter, like larger stumps, may produce one or more sprouts per stump. In this study 42 per cent of such sprout clumps were single stemmed by the time they approached a size for commercial thinning. Thirty-one per cent were twins, and high numbers of sprouts were found considerably less often.

Decay of sprouts from such small stumps is not a factor to consider since such stumps do not usually possess heartwood. When one or more stems of a multiple-stem clump dies or is cut after they are large enough to contain heartwood, decay fungi may enter the sprout clump at such infection courts, and elite stems which were left may later develop butt rot.

If sprouts in a clump derived from a small stump are all alive, not suppressed, and seem likely to survive after 30 or more years, it would be best to treat the clump as a unit. This would involve cutting or leaving all sprouts at the discretion of the person making the thinning, as was suggested in cleanings. All sprouts of such a clump should remain free of heartrot as long as they continue to live and remain uninjured.

If some sprouts of such a clump are suppressed and may be expected to die, remove the entire clump if possible. If this seems unwise, let the suppressed stems die. This is recommended because, once such sprouts are $4-6$ inches in diameter, fungi causing butt rot will penetrate from the stump of the stem removed in thinning into the heartwood of the remaining elite stems. In this study 36 per cent of remaining stems were decayed five to eight years after such a thinning. This figure would be expected to increase with time after thinning.

If the suppressed stems are not removed, heartrot will not enter them until they die, nor will the heartrot spread to the butt of the elite stem 
until at least two years after the suppressed sprout dies, usually not until it has fallen or broken over. Ginns and True (1967) found that 70 per cent of the remaining elite stems of seedling-sprout clumps contained butt decay an estimated two years or more after the death of the suppressed stem.

The recommendation that suppressed sprouts not be removed from a clump is based on the possible time required for the sprout to die plus the additional two years it usually takes for such decay to enter the butt of the decayed stem.

A portion of the stems in a clump may be removed in thinnings in certain instances with little affect on decay increase in the stand. Such situations occur when (a) the remaining stems in a clump are removed by a thinning made within 15 years of an earlier thinning, and (b) the thinning is made within 15 years or so of the harvest cut in evenaged stands or groups.

\section{A SUMMARY OF RECOMMENDATIONS}

When treating a stand which includes sprout-origin yellow-poplar stems the following suggestions may be helpful.

\section{In Cleanings}

(a) Remove the entire sprout clump, by preference, or

(b) Before seedling-sprouts develop heartwood, reduce each clump to a single vigorous stem. Such sprouts should be no more subject to buttdecay than a seedling.

(c) Where small sprouts originate from larger stumps containing heartwood, remove the whole clump or favor one or two stump sprouts originating at or below the groundline. Choose low-origin sprouts which seem likely to develop into desirable vigorous stems after their release from the competition of the more decay-susceptible sprouts which originate higher on the stump. If two sprouts are to be left, they should be widely separated or come from opposite sides of the stump.

\section{In Thinnings}

(a) If all sprouts originating from a single small stump less than 2" in diameter are growing well and none appears likely to die of suppression, do not thin the clump but leave, or remove, the entire clump.

(b) Where sprouts have originated from large stumps, remove the whole clump by preference, or lavor one or two vigorous sprouts that appear to have originated low on the parent stump. If two stems of a clump are left, they should be widely separated. 
(c) If sprout clumps include some stems likely to die of suppression, remove the whole clump. Do not remove living suppressed sprouts. Dead sprouts and the stumps of suppressed sprouts are both infection courts from which decay can often be expected to spread into the bases of the elite stem or stems. Spread of decay into the elite stems should be delayed if suppossed sprouts are allowed to die.

(d) Partial removal of stems within a sprout clump may be made near the end of the harvest cut or when two different thinning operations are made only a few years apart and if in the thinnings, all the sprouts in the clumps are harvested.

\section{Appendix}


Appendix Table 1. Appeisance and Condition of Stumps of Sprout Stems Removed One Year Previously

\begin{tabular}{|c|c|c|c|c|c|c|c|}
\hline Plot & $\begin{array}{l}\text { Sprout } \\
\text { Clunip }\end{array}$ & Stump & $\begin{array}{l}\text { Stump } \\
\text { Height } \\
\text { (cm.) }\end{array}$ & $\begin{array}{l}\text { Stump } \\
\text { Diameter } \\
\text { (cm.) }\end{array}$ & $\begin{array}{l}\text { Season } \\
\text { of } \\
\text { cutting }\end{array}$ & $\begin{array}{c}\text { Treatment } \\
\text { of } \\
\text { Top }\end{array}$ & $\begin{array}{l}\text { Bark Condi- } \\
\text { tion of } \\
\text { Cut Stumps }\end{array}$ \\
\hline \multirow[t]{9}{*}{1} & 53 & 1 & 16.5 & 9.1 & Dormant & Wound dressed & Dead \\
\hline & 110 & 1 & 16.1 & 4.0 & Summer & No treatment & Partly alive \\
\hline & & 2 & 15.1 & 3.2 & Summer & No treatment & Partly alive \\
\hline & 127 & 1 & 9.9 & 4.8 & Dormant & Wound dressed & Dead \\
\hline & & 2 & 10.4 & 3.3 & Dormant & Wound dressed & Dead \\
\hline & 169 & 1 & 18.5 & 9.7 & Summer & Wound dressed & Dead \\
\hline & 172 & 1 & 13.0 & 7.9 & Dormant & No treatment & Dead \\
\hline & 211 & 1 & 12.1 & 11.8 & Dormant & Wound dressed & Dead and off \\
\hline & & 2 & 13.0 & 9.8 & Dormant & Wound dressed & Dead and off \\
\hline \multirow[t]{14}{*}{2} & 3 & 1 & 18.2 & 9.0 & Summer & No treatment & Dead and off \\
\hline & & 2 & 8.8 & 11.6 & Summer & No treatment & Partly alive \\
\hline & & 3 & 12.4 & 7.8 & Summer & No treatment & Dead \\
\hline & 5 & 1 & 18.4 & 8.7 & Summer & Wound dressed & Dead and off \\
\hline & & 2 & 18.4 & 13.4 & Summer & Wound dressed & Dead \\
\hline & & 3 & 9.9 & 10.8 & Summer & Wound dressed & Partly alive \\
\hline & 58 & 1 & 16.0 & 7.5 & Summer & No treatment & Dead \\
\hline & 187 & 1 & 17.0 & 10.6 & Summer & No treatment & Dead \\
\hline & 188 & 1 & 16.7 & 11.8 & Summer & No treatment & Dead and off \\
\hline & & 2 & 8.9 & 10.4 & Summer & No treatment́ & Dead \\
\hline & 236 & 1 & 21.1 & 8.4 & Summer & Wound dressed & Partly alive \\
\hline & & 2 & 18.7 & 7.8 & Summer & Wound dressed & Dead \\
\hline & & 3 & 16.0 & 3.3 & Summer & Wound dressed & Dead and off \\
\hline & 239 & 1 & 14.6 & 9.3 & Summer & Wound dressed & Dead and off \\
\hline
\end{tabular}

Appendix Table 2. Numbers of Fungus Species Obtained from Isolation Areas Showing 1, 2 and 3 Symptoms

\begin{tabular}{|c|c|c|c|c|}
\hline Number of Symptoms & Number of Specie: & s Obtained fron & n Each & Isolation Areal \\
\hline Per Isolation Area & 1 & 2 & 3 & 4 \\
\hline 1 & 101 & 10 & 1 & 0 \\
\hline 2 & 49 & 13 & 3 & 0 \\
\hline 3 & 5 & 0 & 0 & 0 \\
\hline Totals & 158 & 23 & 4 & 0 \\
\hline
\end{tabular}


Appendix Table 3. Association of Isolated Fungi With Symptoms Shown By Regions From Which The Isolations Were Made

\begin{tabular}{|c|c|c|c|c|c|c|c|c|c|c|}
\hline \multirow{2}{*}{ Fungi Isolated } & \multicolumn{2}{|c|}{ Sapwood } & \multicolumn{3}{|c|}{ Symptom Classes ${ }^{a}$} & \multicolumn{2}{|c|}{ Heartwood } & \multirow{2}{*}{$\frac{\text { Symptom }}{3}$} & \multicolumn{2}{|c|}{ Classes $^{b}$} \\
\hline & 1 & 2 & 3 & 4 & 5 & 1 & 2 & & 4 & 5 \\
\hline Fusarium sp. \#1 & 8 & 7 & 4 & 1 & 13 & 0 & 0 & 1 & 2 & 1 \\
\hline Fusarium sp. \# 2 & 3 & 0 & 0 & 0 & 1 & 0 & 0 & 0 & 0 & 0 \\
\hline Fusarium sp. \# 3 & 2 & $\mathrm{C}$ & 0 & 0 & 1 & 0 & 0 & 0 & 0 & 0 \\
\hline Fusarium sp. \#4 & 0 & 0 & 0 & 0 & 0 & 0 & 0 & 0 & 1 & 0 \\
\hline Cephalosporium sp. & 2 & 2 & 0 & 0 & 1 & 0 & 0 & 0 & 0 & 0 \\
\hline Phomopsis sp. & 2 & 2 & 2 & 0 & 5 & 0 & 0 & 0 & 0 & 1 \\
\hline Coniothyrium sp. & 5 & 1 & 0 & 1 & 0 & 0 & 0 & 0 & 0 & 0 \\
\hline Gloeosporium sp. \# 1 & I & 3 & 1 & 0 & 0 & 0 & 0 & 0 & 0 & 0 \\
\hline Gloeosporium sp. \#2 & 3 & 1 & 0 & 1 & 1 & 0 & 0 & 1 & 0 & 0 \\
\hline Penicillium sp. & 1 & 2 & 0 & 0 & 1 & 0 & 0 & 0 & 0 & 0 \\
\hline Trichoderma sp. & 1 & 9 & 0 & 0 & 0 & 0 & 1 & 0 & 0 & 0 \\
\hline Gliocladium sp. & 1 & 1 & 0 & 0 & 0 & 0 & 0 & 0 & 0 & 0 \\
\hline Aspergillus sp. & 1 & 1 & 0 & 0 & 0 & 0 & 0 & 0 & 0 & 0 \\
\hline Subtotal & 30 & 20 & 7 & 3 & 23 & 0 & 12 & 2 & 3 & 2 \\
\hline Polyporus adustus & j & 15 & 7 & 0 & 8 & 1 & 1 & 7 & 0 & 2 \\
\hline Peniophora sp. & 2 & 9 & 3 & 0 & 10 & 3 & 1 & 2 & 2 & 5 \\
\hline Stereum purpureum & 0 & 2 & 7 & 0 & 2 & 0 & 0 & 0 & 0 & 0 \\
\hline $\begin{array}{l}\text { Schizophyllum } \\
\text { commune }\end{array}$ & 0 & 1 & 1 & 0 & 0 & 0 & & 0 & 0 & 0 \\
\hline Pleurotus ostreatus & 0 & 8 & 3 & 0 & 3 & 0 & 0 & 0 & 0 & 0 \\
\hline Polyporus versicolor & 5 & 15 & 5 & 0 & 4 & 0 & 1 & 4 & 0 & 0 \\
\hline Subtotal & 12 & 50 & 26 & 0 & 27 & 4 & 3 & 13 & 2 & 6 \\
\hline Totals & 42 & 70 & 33 & 0 & 50 & 4 & 4 & 15 & 5 & 8 \\
\hline
\end{tabular}

a Descriptive designations: 1-dark stain from stump top, 2-light tawny regions, 3-diffuse brown stain, 4-diffuse gray stain, 5 -diffuse light brown stain.

Descriptive designations: 1-dark brown stain, 2-tawny regions, 3-brown stain, 4-purple siain, 5-dark olive green stain.

Appendix Table 4. Sprouts Decayed In Relation To Percentage of Roots Decayed Per Stump for 14-Year-Old Stumps

\begin{tabular}{|c|c|c|c|}
\hline $\begin{array}{l}\text { Percentage of Roots } \\
\text { Decayed Per Stump }\end{array}$ & $\begin{array}{l}\text { Number of } \\
\text { Sprouts Examined }\end{array}$ & $\begin{array}{l}\text { Sprouts } \\
\text { Number }\end{array}$ & $\begin{array}{l}\text { Decayed } \\
\text { Percentage }\end{array}$ \\
\hline $0-10$ & 77 & 25 & 32 \\
\hline $11-20$ & 21 & 7 & 33 \\
\hline $21-30$ & 8 & 3 & 38 \\
\hline $31-100$ & 9 & 2 & 22 \\
\hline
\end{tabular}


Appendix Table 5. Average Sprout Diameter At Breast Height of 14-Year-Old Sprouts Ix Relation To Height of Sprout Origin

\begin{tabular}{ccc}
\hline $\begin{array}{c}\text { Height of origin classes } \\
\text { (with reference } \\
\text { to Soil Line) }\end{array}$ & $\begin{array}{c}\text { Average Sprout Diameter } \\
\text { (at Breast Height) }\end{array}$ & $\begin{array}{c}\text { Number of Sprouts } \\
\text { examined }\end{array}$ \\
\hline $\begin{array}{c}\text { (in) } \\
-1.5 \text { and below }\end{array}$ & (in) & 19 \\
-0.5 to -1.0 & 4.3 & 21 \\
at soil line & 4.6 & 19 \\
+0.5 to +1.0 & 4.5 & 17 \\
+1.5 to +7.0 & 4.7 & 12 \\
+7.5 and above & 5.4 & 29 \\
\hline
\end{tabular}

\section{LITERATURE CITED}

1. Basham, J. T. and L. D. Taylor. 1965. Occurrence of fungi and bacteria in normai and discolored heartwood of second-growth sugar maple in Ontario. Plant Disease Reptr. 40: $771-774$.

2. Beck, D. E. 1962. Yellow-poplar site index curres. Southeast. Forest. Expt. Sta. Research Note No. 108. 2 p.

3. Betts, H. S. 1954. Yellow-poplar. U.S.D.A. Forest Serv. American Woods Series (Revised, Feb., 1954). 8 p.

4. Bollard, E. G. 1958. Nitrogenous compounds in tree xylem sap. pp. 83-93. In the physiology of forest trees. K. V. Thimmann (Editor). The Ronald Press Co., N.Y. $678 \mathrm{p}$.

5. Boyce, J. S. 1961. Forest pathology (3rd ed.). McGraw-Hill Book Co., X. Y. 572 p.

6. Boyce, S. G. and M. Kaciser. 1961. Why yellow-popular seeds have low viability. Central States Forest. Expt. Sta. Tech. Paper 186. 16 p.

7. Byler, J. W. and R. P. True 1966. Root and butt rot in young yellow-poplar stump sprouts. Phytopathology 56: 1091-1097.

8. Campbell, R. A. 1959. Tree grades give accurate estimate of second-growth yellowpoplar value, Southeast. Forest Expt. Sta. Paper 108. 14 p.

9. Campbell, W. A. 1938. Preliminary report on decay in sprout Northern hardwoods in relation to timber stand improvement. Northeast. Forest Expt. Sta. occassional Paper $7.8 \mathrm{p}$.

10. Carvell, K. L. 1964. Improvement cuttings in immature hardwood stands yield income while increasing future saw timber values. W. Va. Univ. Agr. Expt. Sta. Bull. 492.17 p.

11. Carvell, K. L. and C. F. Korstian. 1955. Production and dissemination of yellowpoplar seed. J. Forestry 53: I69-170.

12. Dochinger, L. S. and C. E. Seliskar. 1962. Fusarium bark canker of yellow-poplar. Phytopathology ( ( 1 bstr.) 52: 8 .

13. Doolittle, WV. T. 1958. Site index comparisons for several forest species in the Southern Appalachians. Soil Sci. Soc. Amer. Proc. 22: $455-458$.

14. Duncan, Catherine G. 1960. Wood-attacking capabilities and physiology of softrot fungi. U. S. Forest Serv. Forest. Prod. Lab. Report No. 2173, 28 p.

15. Ellwood, E. L. and B. A. Ecklund. 1959. Bacterial attack of pine logs in pond storage. Forest Prod. J. 9: 283-292. 
16. Engle, L. G. and R. D. Williams, 1957. Scarifying seedbed boosts yellow-poplar germination. Central States Forest Expt. Sta. Note 110. 2 p.

17. Englerth, G. H. 1942. Decay of Western hemlock in Western Oregon and Washington. Yale Univ., School Forestry Bull. 50. 53 p.

18. Etheridge, D. E. and J. Laut. 1958. Fungi associated with living and dead branches of pole sized Aspen. Bi-mo. Prog. Report, Div. Forest Biol., Dept. Agri. Canada 14: 2-3.

19. Funk, D. T. 1958. Frost damage to yellow-poplar varies by seed source and site. Central States Forest Expt. Sta. Note 155. 2 p.

20. Ginns, J. H. and R. P. True. 1967. Butt rot in yellow-poplar seedling-sprout stands. Forest Sci. 13: 440-447.

21. Good, H. M., P. C. Murray and H. M. Dale. 1955. Studies on heartwood formation and staining in sugar maple, Acer saccharum. Marsh. Can. J. Bot. 33: 31-41.

22. Griffith, N. T. and H. L. Barnett. 1967. Mycoparasitism by basidiomycetes in culture. Mycologia 59: 149-154.

23. Guard, A. T. and R. E. Wean. 1941. Seed production in the tulip poplar. J. Forestry 39: 1032-1033.

24. Hartley, C., R. W. Davidson and B. S. Crandall. 1961. Wet wood, bacteria, and increased pH in trees. U. S. D. A. Forest. Products Lab. Report No. 2215. 34 p.

25. Hawley, R. C. and D. M. Smith. 1958. The practice of silviculture (6th ed.). John Wiley and Sons, Inc., N. Y. 525 p.

26. Hepting, G. H. 1935. Decay following fire in young Mississippi Delta hardwoods. U. S. D. A. Tech. Bull. 494. 32 p.

27. Hepting, G. H. 1941. Prediction of cull following fire in Appalachian oaks. J. Agr. Research 62: 109-120.

28. Hepting, G. H. and G. G. Hedgcock. 1937. Decay in merchantable oak, yellowpoplar, and basswood in the Appalachian region. U. S. D. A. Tech. Bull. 570. 29 p.

29. Hepting, G. H., E. R. Roth and B. Sleeth. 1949. Discolorations and decay from increment borings. J. Forestry 47: 366-370.

30. Holcomb, C. J. and C. A. Bickford. 1952. Growth of yellow-poplar and associated species in West Virginia as a guide to selective cutting. Northeast. Forest Expt. Sta. Paper 52. 28 p.

31. Holsoe, T. 1950. Profitable tree forms of yellow-poplar. W. Va. Univ. Agr. Expt, Sta. Bull. 341. 23 p.

32. - 1951. Yellow-poplar: reaction to crown release and other factors influencing growth. W. Va. Univ. Agr. Expt. Sta. Bull. 344T. 83 p.

33. Laidlaw, R. A. and G. A. Smith. 1965. The proteins of the timber of scots pine (Pinus sylvestris). Holzforschung 19: 129-134.

34. Leach, J. G. 1940. Insect transmission of plant diseases. McGraw-Hill Book Co., N. Y. 615 p.

35. Leffelman, L. J. and R. C. Hawley. 1925. Studies of Connecticut hardwoods. The treatment of advance growth arising as a result of thinnings and shelterwood cuttings. Yale Univ. School of Forestry Bull. $15.68 \mathrm{p}$.

36. Little, E. L., Jr. 1953. Check list of native and naturalized trees of the United States (including Alaska). U. S. D. A. Agr. Handbook 41, 472 p. 
37. McCarthy, E. F. 1933. Yellow-poplar-characteristics, growth and management. U. S. D. A. Tech. Bull. 356.57 p.

38. McCreary, Matilda, B. J. Cosenza and A. L. Shigo. 1965. Bacteria isolated from decars and discolorations in northern hardwoods. Phytopathology (Abstr.) 55: 129130.

39. Merrill, Wr. and E. B. Cowling. 1966. a. Role of nitrogen in wood deterioration: amount and distribution of Nitrogen in fungi. Phytopathology 56: 1083-1090.

40. - . 1966,b. The role of nitrogen in wood deterioration: Amounts and distribution of nitrogen in tree stems. Canad. J. Bot. 44: 1555-1580.

41. Nelson, R. M. 1910. Vigorous young yellow poplar trees can recover from injury by Nectria cankers. J. Forestry $38: 587-588$.

42. Nobles, M. K. 1948. Identification of cultures of wood-rotting fungi. Can. J. Research. C., Botan. Sci. 26: 281-431 (mimeo) .

43. Phillips, J. J. 1962. Some effects of competition on the survival of yellow-poplar Scedlings. Northeast. Forest Expt. Sta. Research Note 134. 4 p.

44. Putnam, J. A., G. M. Furnival and J S. McKnight. 1960. Management and inventory of Southern hardwoods. U. S. D. A. Agr. Handbook 181. 102 p.

45. Renshaw, J. F. and WT. T. Doolittle. 1958. Silvical characteristics of rellowpoplar. Southeast. Forest Expt. Sta. Paper 89. 18 p.

46. Roth, E. R. 1941. Top rot in snow-damaged rellow poplar and basswood. J. Forestry 39: 60-62.

47. Roth, E. R. 1950. Discoloration in living yellow poplar trees. J. Forestry 48: 184-185.

48. Roth, E. R. and G. H. Hepting. 1943a. Origin and development of oak sprouts as affecting their likelihood to decay. J. Forestry 41: 27-36.

49. Roth, E. R. and G. H. Hepting. 1943b. Wounds and decay caused by remoring large companion sprouts of oak. J. Forestry 41: 190-195.

50. Roth, E. R. and B. Sleeth. 1939. Butt rot in unburned sprout oak stands. U. S. D. A. Tech. Bull. 684. 42 p.

51. Savory, J. C. 1954. Breakdown of timber by ascomycetes and fungi imperfecti. Ann. Appl. Biol. 41: 336-347.

52. Shigo, A. L. 1962. Obserrations on the succession of fungi on hardwood pulprood bolts. Plant Disease Reptr. 46: 379-380.

53. - - 1963. Fungi associated with the discolorations around rot columns caused by Fomes igniarus. Plant Disease Reptr. 47: 820-823.

54. - 1965a. Patterns of decays and discolorations in northern hardwoods. Phytopathology 55: 648-652.

55. - $1965 \mathrm{~b}$. Organism interactions in decav and discoloration in beech. birch and maple. U. S. Forest Serv. Research Paper NE-43. 23 p.

56. -1965c. Decay and discoloration in sprout red maple. Phrtopathology 55: 957-962.

57. Strausbaugh, P. D. and E. L. Core. 1964. Flora of West Virginia. W. Va. Univ. Bull., Series 65, No. 3-1, see p. vint.

58. Trimble, G. R., Jr. and G. Hart. 1961. An appraisal of early reproduction after cutting in northern Appalachian hardwood stands. Northeast. Forest Expt. Sta. Paper 162. 22 p. 
59. True, R. P. 1953. Studies of sprout reproduction of yellow poplar as related to decay. W. Va. Univ. Agr. Expt. Sta. Current Report 3. 4 p.

60. -1962. Decay in thinned sprout clumps of yellow-poplar. Phytopathology (Abstr.) 52: 486.

61. Tryon, E. H., J. O. Cantrell and K. L. Carvell. 1957. Effect of precipation and temperature on increment of yellow-poplar. Forest Sci. 3: 34-44.

62. Tryon, E. H. and K. L. Carvell. 1960. Environmental factors affecting yellowpoplar survival under a young stanci. Castanea 25: 69-73.

63. Tryon, E. H. and C. A. Myers. 1952. Periodic precipitation affects growth of yellow-poplar on a West Virginia hillside. Castanea 17: 97-102.

64. Tryon, E. H. and R. P. True. 1952. Blister-shake of yellow-poplar. W. Va. Univ. Agri. Expt. Sta. Bull. 350T. 15 p.

65. - - 1964. Relative susceptibility of Appalachian hardwood species to spring frosts occurring after bud break. W. Va. Univ. Agr. Expt. Sta. Bull. 503.15 p.

66. Verrall, A. F. 194l. Dis cmination of fungi that stain logs and lumber. J. Agr. Research 63: 549-558.

67. Wahlenberg, W. G. 1953. Three methods of rehabilitation for depleted Appalachian hardwood stands. J. Forestry 51: 874-880. 


yom 